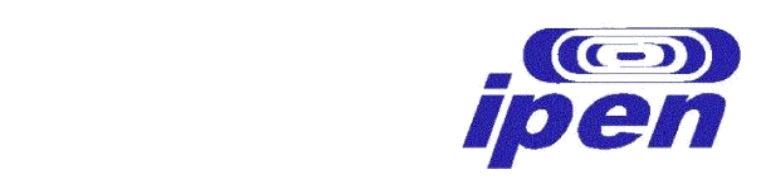

AUTARQUIA ASSOCIADA À UNIVERSIDADE DE SÃO PAULO

ESTUDOS DE COMPACTAÇÃO DE PÓ DE NÍQUEL PARA PRODUÇÃO DE ALVOS DE IRRADIAÇÃO

ROSANA STACCHINI LOURENÇO MIYANO

Dissertação apresentada como parte dos requisitos para obtenção do Grau de Mestre em Ciências na Área de Tecnologia Nuclear - Materiais

Orientador:

Dr. Jesualdo Luiz Rossi

SÃO PAULO

2014 


\section{DEDICATÓRIA}

À Flavia e ao Davi, 


\section{AGRADECIMENTOS}

Meus sinceros agradecimentos,

Ao meu orientador, Prof. Dr. Jesualdo Luiz Rossi por me aceitar como sua aluna e, principalmente, por me ajudar nos momentos difíceis no decorrer da elaboração deste trabalho.

À Prof. Dra. Isolda Costa pelo incentivo e apoio fundamentais para a conclusão desta pesquisa.

Ao Prof. Dr. Hidetoshi Takiishi pela participação, disponibilidade de laboratório e equipamentos e interesse no melhor resultado para andamento do trabalho.

Ao Me. Edson Pereira Soares do Laboratório de Materiais Magnéticos pelo auxílio na execução de ensaios de sinterização.

Ao Me. Mariano Castagnet do Laboratório de Comportamento Mecânico e ao Sr. Pedro Pinto de Freitas do Laboratório de Cerâmica pela dedicação e auxílio na execução de vários ensaios.

Ao Me. Gilberto Hage Marcondes e Sr. Jorge Clementino dos Santos do CCN por colaboração nas análises iniciais deste trabalho.

A Dra. Lusinete Pereira Barbosa, pela paciência, apoio técnico, encorajamento e por acompanhar de perto o andamento deste trabalho.

Aos funcionários da Biblioteca e da Pós-Graduação do IPEN, pelos serviços prestados.

Ao prof. Dr. Paulo Antônio Pereira Wendhausen, Me. Leandro Lima Evangelista, do Departamento de Engenharia Mecânica - Laboratório de Materiais da Universidade Federal de Santa Catarina, pelas sugestões, colaboração técnica, atenção e disponibilidade.

A empresa Grupo Combustol \& Metalpó, na pessoa do Sr. Marcelo lasi, pela ajuda inestimável, pela cordialidade e disposição na sinterização de algumas amostras.

A todos os amigos que ajudaram a tornar esta etapa percorrida muito mais prazerosa: Emanuelle, Sonia, Kelly, Igor, Felipe, Raquel, Débora, Victor e Jefferson.

Aos Professores Fabiano Takashi Morimoto e Roberto Lopes dos Santos 
da Escola Prof. Leandro de Barros Pimentel, pela ajuda, sugestão e colaboração no andamento deste trabalho.

Ao meu marido, Carlos Yaiti Miyano pela paciência e apoio dispensados durante os anos de realização deste trabalho.

A grande amiga Cláudia Ponte-Ponge pela amizade e pelas broncas nos momentos de desanimo e impaciência em que tudo parecia dar errado.

A todos que colaboraram direta ou indiretamente na elaboração e execução deste trabalho, o meu reconhecimento. 


\title{
ESTUDOS DE COMPACTAÇÃO DE PÓ DE NÍQUEL PARA PRODUÇÃO DE ALVOS DE IRRADIAÇÃO
}

\section{Rosana Stacchini Lourenço Miyano}

\begin{abstract}
RESUMO
O objetivo deste trabalho foi desenvolver uma forma alternativa de se produzir alvos para irradiação contendo urânio, destinados à produção do par de radionuclídeos ${ }^{99} \mathrm{Mo}^{99 \mathrm{~m}} \mathrm{Tc}$. Estes alvos foram obtidos por metalurgia do pó, utilizando-se pós de níquel e de cobre, servindo o compactado como meio de encapsulamento para um cilindro de urânio a ser irradiado. $O$ desenvolvimento compreendeu as etapas de caracterização química e física dos pós-utilizados. Os alvos foram compactados em prensa uniaxial e em prensa isostática a frio. As amostras foram sinterizadas em três atmosferas diferentes: argônio, hidrogênio e em alto vácuo. Quando do uso conjunto de cobre e níquel, foi feita sinterização por dois corpos, i.e., um compactado de níquel contendo o núcleo para ser irradiado e um compactado de cobre para servir de infiltrante. Isto, visando a eliminação de porosidade interconectada, permitindo o selamento do conteúdo físsil no interior do compactado. Os alvos após sinterização foram caracterizados fisicamente sendo avaliada a massa específica, pelo método geométrico e pelo princípio de Arquimedes. A porosidade foi medida pela técnica de porosimetria de mercúrio. Os alvos prontos foram caracterizados micro estruturalmente por microscopia óptica e eletrônica de varredura. Os resultados indicaram que a densificação do níquel foi diretamente proporcional à pressão de compactação obtendo-se $87 \%$ de densidade relativa após prensagem a $800 \mathrm{MPa}$ (limite superior de compactação para ligas metálicas) e sinterização por $4 \mathrm{~h}$ a $600{ }^{\circ} \mathrm{C}$ em atmosfera de hidrogênio. A sinterização por dois corpos (níquel com cobre) mostrou-se promissora para o uso como invólucro para núcleos, em termos de integridade estrutural e selamento devido à ausência de porosidade interconectada.
\end{abstract}

Palavras-chave: metalurgia do pó, compactados de níquel, sinterização, alvos de irradiação. 


\title{
STUDIES OF NICKEL POWDER COMPACTION FOR PRODUCTION OF IRRADIATION TARGETS
}

\section{Rosana Stacchini Lourenço Miyano}

\begin{abstract}
The objective of this work was to develop an alternative way to obtain targets for irradiation, containing uranium, destined for the production of the radionuclide pair ${ }^{99} \mathrm{Mo-}{ }^{99 \mathrm{~m}} \mathrm{Tc}$. The targets were obtained using powder metallurgy using nickel and cooper powders, serving the compact as a medium for encapsulation of a uranium cylinder to be radiated. The development started with the chemical and physical characterization of the used powders. The targets were compacted either in uniaxial press and cold press isostatic. The samples were sintered at three different atmospheres: argon, hydrogen and high vacuum. In the case of use of nickel and copper, it was used the two bodies technique for sintering, i.e., a nickel compact containing a core to be irradiated and the cooper used as infiltrant. This was aiming at the elimination of interconnected porosity, allowing the sealing of any fissile content in the interior of the compact. The targets were physically characterized after sintering the density being evaluated by geometrical method and the Archimedes' principle. The porosity was measured by the technique of mercury porosimetry. The targets were microstructurally characterized using optical and scanning electronic microscopy. The results indicated that the nickel densification was directly proportional to the compaction pressure yielding $87 \%$ relative density after pressing at $800 \mathrm{MPa}$ (upper limit for alloys compaction) and sintering for $4 \mathrm{~h}$ at $600{ }^{\circ} \mathrm{C}$ in hydrogen atmosphere. Sintering of two bodies (nickel and copper) has shown some feasibility for use as core casing in terms of structural integrity and sealing due to the absence of interconnected porosity.
\end{abstract}

Keywords: powder metallurgy, nickel compaction, sintering, irradiation targets 


\section{SUMÁRIO}

Assunto

Página

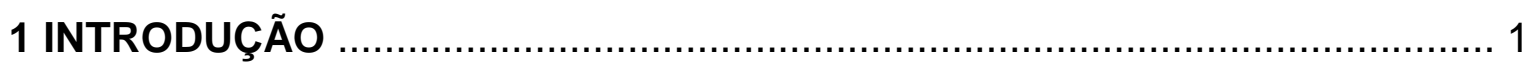

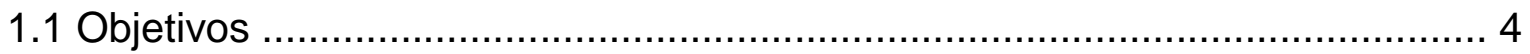

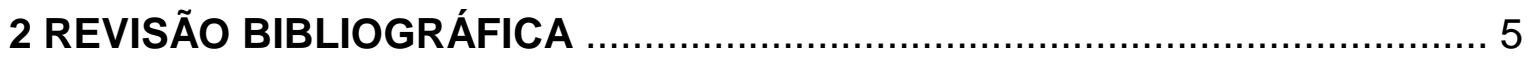

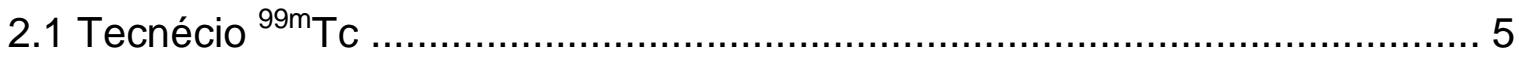

2.2 Produção do ${ }^{99}$ Mo em reatores nucleares ............................................. 7

2.3 Alvos do tipo LEU em uso na América do Sul ......................................... 9

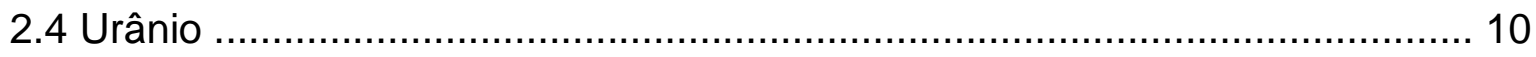

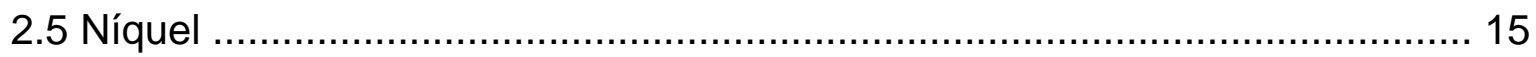

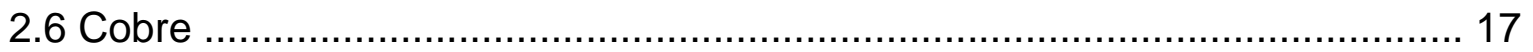

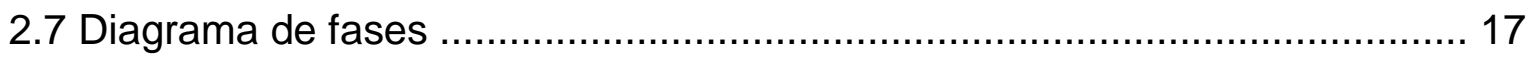

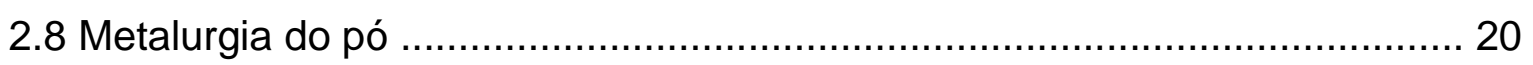

2.8.1 Produção do pó (métodos básicos) ............................................ 24

2.8.2 Formato dos pós e suas características ...................................... 28

2.8.3 Mistura dos componentes .......................................................... 32

2.8.4 Moldagem ou compactação .................................................... 32

2.8.5 Aquecimento ou sinterização .............................................. 35

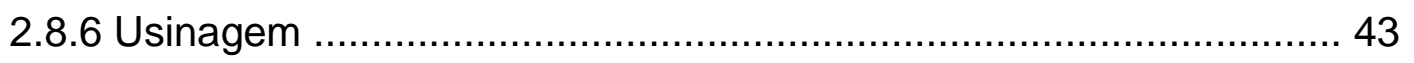

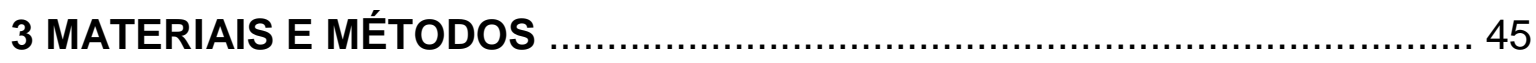

3.1 Caracterização dos pós - primeira etapa ................................................ 46

3.2 Obtenção dos compactados de níquel com tempo de sinterização de 2 a $24 \mathrm{~h}$

- segunda etapa ................................................................................... 47

3.2.1 Caracterização do compactado a verde e sinterizado ................... 51

3.2.2 Microscopia eletrônica após compactação .................................. 51

3.2.3 Ensaio de compressão ..................................................... 52

3.2.4 Porosimetria por intrusão de mercúrio ..................................... 53

3.3 Obtenção dos compactados de níquel - segunda etapa .............................. 54

3.4 Obtenção dos compactados de níquel - terceira etapa ............................... 55

3.5 Obtenção dos compactados de níquel - quarta etapa ................................. 55

3.6 Obtenção dos compactados de níquel - quinta etapa ................................. 57

3.7 Obtenção dos compactados de níquel - sexta etapa ................................. 57 


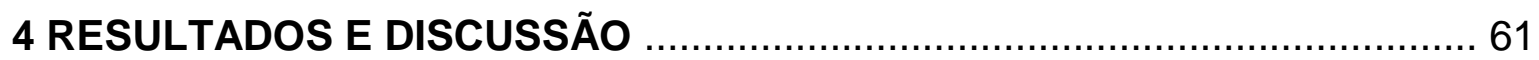

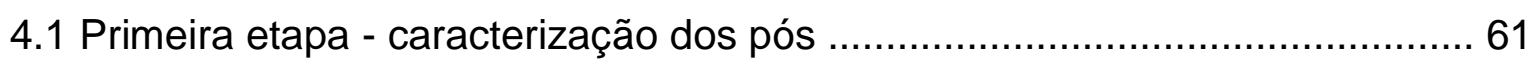

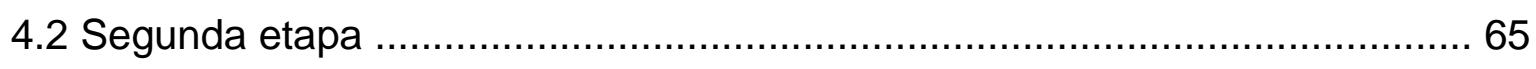

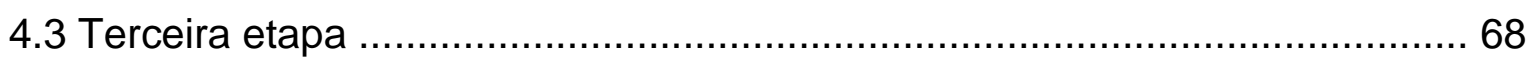

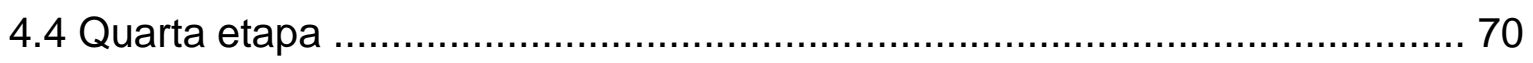

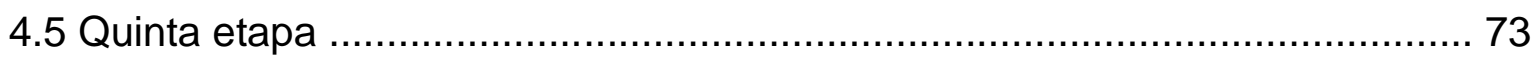

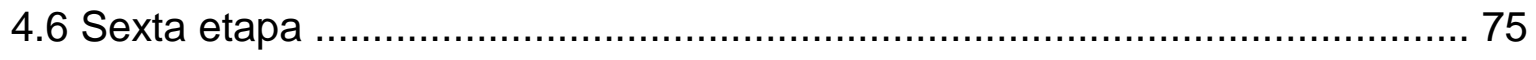

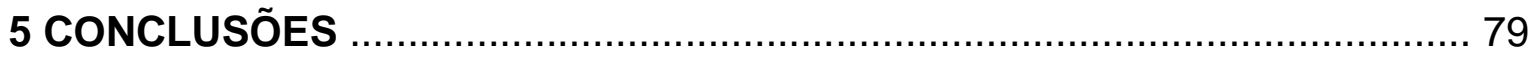

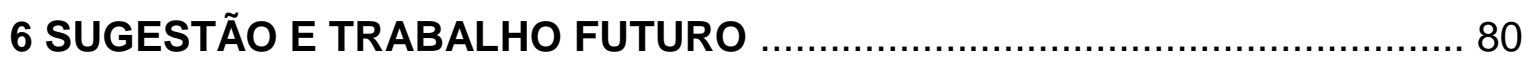

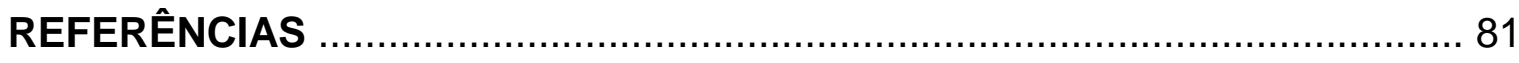




\section{LISTA DE FIGURAS}

Página

Figura1. Esquema ilustrando a confecção de um alvo tradicional tipo moldura baseado na dispersão da liga $\mathrm{UAl}_{\mathrm{x}}$ em uma matriz de alumínio (Saliba et al., 2011). 2

Figura 2. Estrutura do alvo chileno (Schrader et al., 2008). ............................... 3

Figura 3. Esquema de decaimento do ${ }^{99 \mathrm{~m}} \mathrm{Tc}$ (Boyd, 1982).............................. 6

Figura 4. Gerador de tecnécio produzido pelo IPEN/CNEN-SP (cortesia IPEN/CNEN - SP). 6

Figura 5. Esquema do decaimento radioativo do ${ }^{99} \mathrm{Mo}(\mathrm{TI}=$ Transição isomérica $)$ (Boyd, 1982).

Figura 6. Rendimento de produção de fissão térmica versus número de massa (Takahashi, 2004 e alteração do autor).

Figura 7. Efeito do níquel na resistência a corrosão de alguns metais duros (ASM, 2000).

Figura 8. Representação esquemática do equilíbrio $S / L$ para um sistema do tipo eutético (Almeida, 2009). 18

Figura 9. Diagrama de fases níquel - urânio (Chakrabarti e Peterson, 1990). ... 19

Figura 10. Diagrama de fases cobre - urânio (Chakrabarti e Peterson, 1990). ... 19

Figura 11. Diagrama de fases no sistema Cu-Ni (Chakrabarti e Peterson, 1990).

Figura 12. Consumo de material e energia necessária para produzir $1 \mathrm{~kg}$ do produto acabado (Zapata, 1987). 22

Figura 13. Representação esquemática das várias etapas do processo de metalurgia do pó, com destaque para as etapas fundamentais (Chiaverini, 2001).

Figura 14. Representação esquemática do processo de atomização em água (Chiaverini, 2001). 26

Figura 15. Representação esquemática do processo de atomização a gás: (a) configuração de dois jatos e (b) configuração "anel anular" (Chiaverini, 2001) . .. 27 Figura 16. Coleção de possíveis formas de partículas (German, 1984). 29

Figura 17. Seis possíveis medidas do tamanho da partícula (Allen, 1997). 30

Figura 18. Representação dos diferentes tipos de poro: (a) fechados, (b) gargalo e 
garrafa, (c) cilíndricos, (d) afunilados, (e) interconectados, (f) irregulares. A letra (g) representa a rugosidade da superfície (Rouquerol, 1994). 31

Figura 19. Estágios da movimentação das partículas na cavidade de uma matriz durante o processo de compactação (German, 1984). 33

Figura 20. Desenho esquemático de uma ferramenta para compactação e obtenção do material à verde (German, 1984). 33

Figura 21. Efeito ilustrativo da operação de sinterização sobre várias características do material (Henry, 1973). 35

Figura 22. Formação de pescoço (neck) em consequência da ligação inicial entre as partículas (German, 1984). 38

Figura 23. Estágios da sinterização por fase líquida (German, 1984). 42

Figura 24. Torneamento cilíndrico externo de um material obtido pela metalurgia do pó (German, 1984). 44

Figura 25. Esboço da sequência de infiltração de um material. Forças de capilaridade puxam o metal fundido para dentro dos poros abertos (German, 1984).

Figura 26. Imagem do compactado de níquel utilizado. 48

Figura 27. Prensa hidráulica com capacidade máxima de 10 toneladas. 48 Figura 28. Para a primeira etapa da pesquisa foram compactadas amostras de níquel com pressão de compactação de $195 \mathrm{MPa}$ 49

Figura 29. Forno tipo mufla utilizado na sinterização, com cavacos de titânio, dos compactados de níquel, a $600{ }^{\circ} \mathrm{C}$ por $24 \mathrm{~h}$. 50

Figura 30. Ciclo térmico de sinterização adotado para os compactados obtidos e sinterizados, juntamente com os cavacos de titânio, na temperatura de $600{ }^{\circ} \mathrm{C}$ por um período de até $24 \mathrm{~h}$. 50

Figura 31. Politriz utilizada para o polimento final de amostras metalográficas em sílica coloidal 0,02 $\mu \mathrm{m}$. 52

Figura 32. Ciclo térmico de sinterização com rampa de aquecimento adotado para os compactados obtidos e sinterizados na temperatura de $600 \stackrel{\circ}{\mathrm{C}}$ por um período de $4 \mathrm{~h}$ em atmosfera de hidrogênio. 54

Figura 33. Ciclo térmico de sinterização com rampa de aquecimento adotado para os compactados obtidos e sinterizados na temperatura de $600 \stackrel{\circ}{\circ}$ por um período de $4 \mathrm{~h}+8 \mathrm{~h}$ em atmosfera de hidrogênio. 55 Figura 34. Forno tubular utilizado na sinterização dos compactados de níquel, 
utilizando como atmosfera de sinterização o argônio. 56

Figura 35. Forno tubular utilizado na sinterização dos compactados de níquel, utilizando como atmosfera de sinterização o vácuo. 56

Figura 36. Forno contínuo industrial com emprego de atmosfera de $70 \%$ de $\mathrm{H}_{2}$ e $30 \%$ de $\mathrm{N}_{2}$ e temperatura de $1150{ }^{\circ} \mathrm{C}$ da empresa Combustól Metalpó . 57 Figura 37. Impressão artística de uma pastilha de urânio metálico em pó (interno) e níquel em pó (externo). 58

Figura 38. a) Perspectiva do desenho do compactado, com o núcleo de aço inox simulando o núcleo de urânio no centro do compactado. b) Cálculo da massa de níquel utilizada para construir este compactado. 58

Figura 39. Compactado de níquel já com núcleo em aço AISI 304. 59 Figura 40. Prensa isostática a frio com capacidade para $700 \mathrm{MPa}$ (100000 psi). 60 Figura 41. Espectro de energia dispersiva (EDS) obtido no microscópio eletrônico de varredura do pó de níquel usado neste trabalho. 62 Figura 42. Curva da distribuição granulométrica do pó de níquel. $D_{10 \%}=10,29 \mu \mathrm{m}$. $D_{50 \%}=23,80 \mu \mathrm{m}$. $D_{90 \%}=41,31 \mu \mathrm{m}$.

Figura 43. Microscopia eletrônica de varredura em uma amostra do pó de níquel utilizado, aderido a uma fita carbono. 64

Figura 44. Variação da densidade dos compactados com o tempo em h na sinterização a $600^{\circ} \mathrm{C}$ em atmosfera protegida com cavacos de titânio. 66 Figura 45. (a) Micrografia eletrônica de varredura com elétrons retro-espalhados do compactado de níquel sinterizada por $3 \mathrm{~h}$ mostrando os grãos de níquel contraste claro, fase em contorno de grão contraste cinza e porosidade contraste escuro. (b) Micrografia eletrônica de varredura com elétrons retro-espalhados do compactado de níquel sinterizada por $5 \mathrm{~h}$. Ataque água régia.

Figura 46. Gráfico da variação da carga de compressão com o deslocamento do travessão em amostras de compactado de níquel à verde e com diferentes tempos de sinterização a $600^{\circ} \mathrm{C}$. 68

Figura 47. Gráfico de compressibilidade referente à compactação em 10 amostras de níquel com diferentes pressões de compactação.

Figura 48. Gráfico referente à massa das amostras compactadas antes e após sinterização por um período de 4 e 8 horas de patamar.

Figura 49. Gráfico da variação da carga de compressão com o deslocamento do travessão em amostras de compactado de níquel no tempo de $24 \mathrm{~h}$ de 
sinterização a $600{ }^{\circ} \mathrm{C}$ e compactada a $206 \mathrm{MPa}$ em prensa isostática, em atmosferas controladas de argônio, hidrogênio e vácuo. 70 Figura 50. (a) Micrografia óptica do centro do compactado de níquel após tempo de $24 \mathrm{~h}$ de sinterização, compactado em prensa isostática, sinterizada a $600{ }^{\circ} \mathrm{C}$ em atmosfera controlada de argônio. (b) Micrografia óptica da borda do compactado de níquel mostrando uma alta porosidade. Sem ataque. 71

Figura 51. (a) Micrografia óptica do centro do compactado de níquel após tempo de $12 \mathrm{~h}$ de sinterização, compactado em prensa isostática, sinterizada a $600{ }^{\circ} \mathrm{C}$ em atmosfera controlada de hidrogênio. (b) Micrografia óptica da borda do compactado de níquel mostrando alta porosidade. Sem ataque. 72 Figura 52. (a) Micrografia óptica do centro do compactado de níquel após tempo de $12 \mathrm{~h}$ de sinterização, compactado em prensa isostática, sinterizada a $600{ }^{\circ} \mathrm{C}$ em atmosfera controlada de alto vácuo. (b) Micrografia óptica da borda do compactado de níquel mostrando uma alta porosidade e um destacamento da camada lateral externa. 72

Figura 53. Compactado de cobre na forma de disco usado para a sinterização em dois corpos (níquel e cobre)

Figura 54. Compactados de níquel utilizado após infiltração com o cobre. Nota-se na superfície superior do compactado de níquel a presença de uma crosta de cobre. Este compactado já foi feito com o núcleo em aço AISI 304. 74

Figura 55. (a) Micrografia óptica mostrando o aspecto do compactado de níquel com infiltração de cobre, evidenciando ainda a presença de poros. (b) Ilhas de cobre, contraste rosa, dentro do sinterizado de níquel. 75

Figura 56. Micrografia óptica mostrando o aspecto do material com infiltração de cobre, nesta região o cobre está em fase contínua, contraste rosa, em níquel, contraste azul claro. 75

Figura 57. Interface entre o sinterizado ou invólucro de níquel e o núcleo de aço inoxidável AISI 304. 76

Figura 58. Micrografia óptica mostrando interfaces níquel/cobre com o núcleo em aço AISI 304. 76

Figura 59. Micrografia óptica mostrando trinca na porção sinterizada do compactado com origem na superfície.

Figura 60. Micrografia eletrônica de varredura de um corte do compactado de níquel com o núcleo em aço AISI 304. 
Figura 61. Micrografia eletrônica de varredura com elétrons retro-espalhados de um corte do compactado sinterizado de níquel com infiltração de cobre. Foi observado que a borda ficou porosa. 78 


\section{LISTA DE TABELAS}

Página

Tabela 1. Alvos de urânio utilizados para a produção do ${ }^{99} \mathrm{Mo}$ ou planejados para serem utilizados no futuro por diferentes produtores (Nishiyama, 2012). 8

Tabela 2. Principais produtores de ${ }^{99}$ Mo utilizando alvos em reatores nucleares (Nishiyama, 2012).

Tabela 3. Abundância natural dos isótopos de urânio (Lederer e Shirley, 1978). 12

Tabela 4. Isótopos do urânio (Katz e Seaborg, 1957). 13

Tabela 5. Propriedade física e química do urânio (Katz e Seaborg, 1957). ........ 14

Tabela 6. Propriedades mecânicas do urânio (Katz e Seaborg, 1957). .............. 14

Tabela 7. Propriedades do níquel (Deyoung et al., 1985). .............................. 16

Tabela 8. Temperaturas e tempos de sinterização para alguns materiais

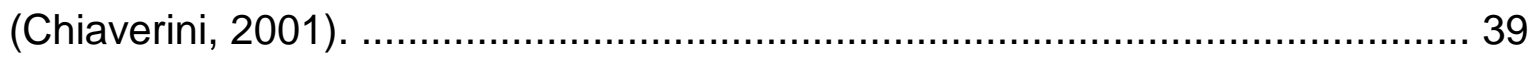

Tabela 9. Características dos pós-utilizados no presente trabalho. ...................61 61

Tabela 10. Resultados de análise química semi-quantitativa (\% em massa) obtidos no ensaio de fluorescência de raios $X$ por dispersão de comprimento de onda, em uma amostra do pó de níquel utilizado neste trabalho. 62

Tabela 11. Resultados de análise química (\% em massa), do pó de cobre EF-98S utilizado neste trabalho, segundo o fornecedor (lasi, 2014).

Tabela 12. Resultado de ensaios de densidade aparente e escoabilidade efetuados no pó de cobre EF-98S utilizado neste trabalho (Iasi, 2014). .64

Tabela 13. Distribuição granulométrica do pó de cobre EF-98S utilizado neste trabalho, segundo o fornecedor (Iasi, 2014). 65

Tabela 14. Variação média da densidade com o tempo de sinterização a $600{ }^{\circ} \mathrm{C}$ (média de 3 amostras). A densificação é relativa entre um tempo de sinterização em h e o próximo intervalo. 66 


\section{INTRODUÇÃO}

O estudo continuado da energia nuclear tem proporcionado 0 desenvolvimento de diversas técnicas e aplicações das mesmas. Dentre essas, devido à sua crescente utilização pela sociedade, pode-se destacar a produção de radioisótopos para uso na medicina nuclear em diagnósticos e terapia, na biologia e na indústria. Além da pesquisa básica fundamental envolvendo isótopos radioativos, os estudos que visam suas aplicações requerem que eles estejam disponíveis em quantidade suficiente e com alta pureza.

O tecnécio-99m ( $\left.{ }^{99 \mathrm{~m}} \mathrm{Tc}\right)$, produto de decaimento do molibdênio-99 $\left({ }^{99} \mathrm{Mo}\right)$, é um dos radioisótopos mais utilizados para o diagnostico de diversas doenças que incluem detecção de tumores, risco de infarto, obstruções renais, demências e outras (Araujo, 2014). As características nucleares do ${ }^{99 \mathrm{~m}} \mathrm{Tc}$ permitem o processamento de imagens de alta qualidade proporcionando baixas doses de radiação aos pacientes (Nishiyama, 2012).

Após a irradiação, $0{ }^{99} \mathrm{Mo}$ é separado do urânio e dos outros produtos de fissão por meio de processos químicos e preparado para distribuição aos centros de consumo (Sameh et al., 1989). Distribuído para hospitais e clínicas na forma de gerador, é empregado em mais de $80 \%$ de todos os procedimentos de radiodiagnóstico médico no mundo (International Atomic Energy Agency, 2010).

O IPEN/CNEN-SP importa todo $0{ }^{99}$ Mo usado no país, que atinge aproximadamente $450 \mathrm{Ci}$ por semana e cerca de $24.000 \mathrm{Ci}$ por ano, sendo que até 2009 o principal fornecedor era a MDS Nordion do Canadá. $\mathrm{O}{ }^{99} \mathrm{Mo}$ importado pelo Brasil representa $4 \%$ da produção mundial (Nishiyama, 2012).

Atualmente 95 a $99 \%$ de todo o ${ }^{99} \mathrm{Mo}$ é produzido em reatores de pesquisa, teste de materiais e de produção de radioisótopos pela irradiação de alvos de urânio altamente enriquecido (high enriched uranium - HEU, geralmente com a concentração isotópica do $235 \mathrm{U}$ atingindo $93 \%$ ). Este valor alto da concentração isotópica leva ao entendimento como sendo um fator de facilitação da proliferação nuclear. Alvos para este tipo de produção são geralmente no formato de: 
- mini-placas e varetas revestidas de Al, contendo ligas de U-Al ou dispersão do tipo UAlx (Cols et al.,1994) ou;

- um filme fino de $\mathrm{UO}_{2}$ envolvendo a parede interna de um tubo de aço inox. (Jones, 1982).

Devido à possibilidade de utilização de HEU para fins militares foi criado o programa Reduced Enrichment for Research and Test Reactors (RERTR) liderado desde 1978 pelo Argonne National Laboratory (ANL) com o objetivo de reduzir o enriquecimento de urânio para o tipo empobrecido (low enriched uranium - LEU, geralmente com a concentração isotópica menor que $20 \%$ de ${ }^{235} \mathrm{U}$ ) (Vandegrift et al., 2007). Atualmente, entre 1 a $5 \%$ da produção mundial remanescente de ${ }^{99} \mathrm{Mo}$ é obtida pela irradiação de alvos com baixo enriquecimento de urânio (Cristini et al, 2002).

Para produção de ${ }^{99} \mathrm{Mo}^{-99 \mathrm{~m}} \mathrm{Tc}$, o IPEN/CNEN-SP começou em 2011 a desenvolver um alvo de irradiação LEU, semelhante ao produzido na Argentina. Esse alvo, do tipo moldura, é baseado na dispersão da liga UAI ${ }_{x}$ em uma matriz de alumínio, conforme esquematizado na Fig. 1.
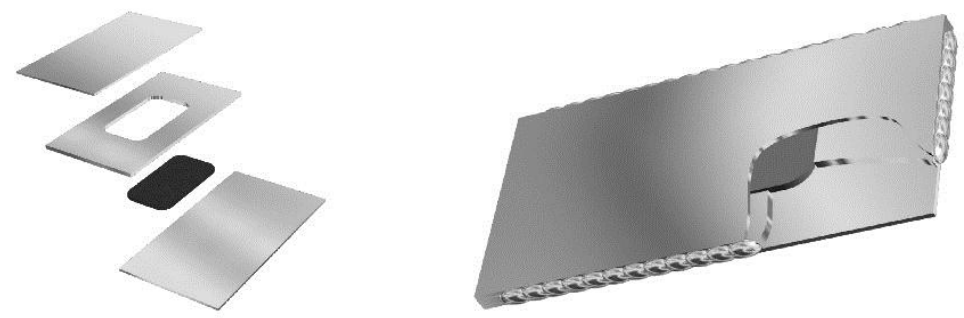

Figura 1. Esquema ilustrando a confecção de um alvo tradicional tipo moldura baseado na dispersão da liga $\mathrm{UAl}_{\mathrm{x}}$ em uma matriz de alumínio (Saliba et al., 2011).

As mini-placas de alvos $\mathrm{UAl}_{x}-\mathrm{Al}$ apresentam as dimensões externas de 52 $\mathrm{mm}$ de largura, $170 \mathrm{~mm}$ de comprimento e $1,52 \mathrm{~mm}$ de espessura. $O$ cerne de UAI $x_{x}-A l$ terá $40 \mathrm{~mm}$ de largura, $118 \mathrm{~mm}$ de comprimento e $0,76 \mathrm{~mm}$ de espessura. Os cálculos neutrônicos revelaram a quantidade de urânio que será colocado no núcleo desta dispersão. Os alvos estão planejados para ter um peso total de $2,0 \mathrm{~g}$ de ${ }^{235} \mathrm{U}$ ou cerca de $10 \mathrm{~g}$ de urânio metálico $\left(20 \%\right.$ em peso ${ }^{\mathrm{LEU} U} \mathrm{U}$ enriquecido com ${ }^{235} \mathrm{U}$, a parte restante é de $80 \%$ em peso de ${ }^{238} \mathrm{U}$ ). Com base nesses valores, tem- 


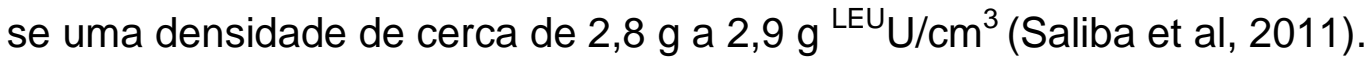

Outra referência para esse trabalho em relação ao volume de urânio metálico que tem sido cogitado é o alvo U-Ni em folha fina, conceitualmente um projeto que envolve a Comissão Chilena de Energia Nuclear - CCHEN. Trata-se de uma folha fina de urânio metálico de $50 \mathrm{~mm}$ de largura, $100 \mathrm{~mm}$ de comprimento e 0,13 $\mathrm{mm}$ de espessura, revestida com uma camada de 0,015 $\mathrm{mm}$ de níquel, contendo $13 \mathrm{~g}$ de ${ }^{L E U} U$, colocada entre dois tubos concêntricos de alumínio selado para irradiação (Nishiyama, 2012). A estrutura do alvo chileno é mostrada na Fig. 2.

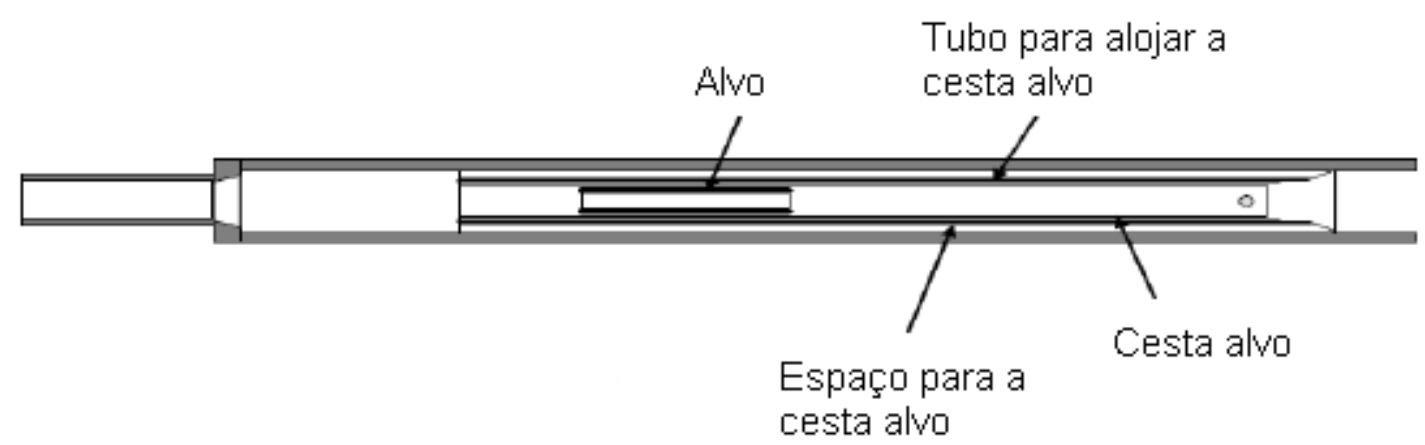

Figura 2. Estrutura do alvo chileno (Schrader et al., 2008).

Os alvos de irradiação para produção do radionuclídeo ${ }^{99}$ Mo serão fabricados com ligas de $U A I_{x}$ no futuro Reator Multipropósito Brasileiro (RMB). No entanto, o material estrutural a ser utilizado é o alumínio, já em uso nesse processo em outros países.

O invólucro de níquel, ao invés de alumínio, pode ser uma rota alternativa para produção de alvos. Esses alvos teriam vantagens no pós-processamento, durante a abertura química do material irradiado, utilizando a rota de dissolução ácida. A literatura mostra que Hofman, et al, (Argonne National Laboratory - 1996) também trabalharam no sentido de desenvolver um metal como candidato a formar barreira de recuo em um alvo de irradiação. Quatro metais foram assim selecionados como candidatos a barreira: cobre, níquel, ferro e zinco, sendo que o principal requisito para a escolha destes metais é de natureza química. Este metal não deve interferir com a dissolução e purificação no processo de obtenção do ${ }^{99} \mathrm{Mo}$. Os metais: cobre, níquel e ferro são adequados para o processo de dissolução ácida e a faixa de recuo para o $\mathrm{Cu}$ e $\mathrm{Ni}$ é aproximadamente $7 \mu \mathrm{m}$. 
Uma barreira de $10 \mu \mathrm{m}$ de espessura deve parar todos os átomos de recuo de alcançar a superfície do alvo.

\subsection{Objetivo}

Desenvolver uma forma alternativa de se produzir alvos para irradiação contendo urânio, destinados à produção do par de radionuclídeos ${ }^{99} \mathrm{Mo-}{ }^{99 \mathrm{~m}} \mathrm{Tc}$, utilizando-se a rota da metalurgia do pó. Como objetivo específico pode-se destacar o estudo do comportamento de compactados de níquel e cobre em diferentes pressões e sinterizados em fornos em diferentes atmosferas. 


\section{REVISÃO BIBLIOGRÁFICA}

\subsection{Tecnécio - ${ }^{99 m} \mathrm{Tc}$}

O elemento químico tecnécio, que na Tabela Periódica apresenta o número atômico 43, foi descoberto em Palermo na Itália em 1937, por Segré e Perrier, que utilizavam o cíclotron da Universidade da Califórnia em Berkeley. Com o desenvolvimento do reator nuclear, foi possível produzir esse elemento pela fissão do urânio, recebendo o nome de "tecnécio", por ser produzido artificialmente (Lederer e Shirley, 1978). Por vários anos, após a descoberta do tecnécio, este permaneceu somente como uma curiosidade científica. A partir de 1950, o campo da medicina nuclear foi modificado com o desenvolvimento do gerador de ${ }^{99} \mathrm{Mo} /{ }^{99 \mathrm{~m}} \mathrm{Tc}$.

O primeiro gerador de ${ }^{99 \mathrm{~m}} \mathrm{Tc}$ foi idealizado por Walter Tucker e Margaret Guine, responsáveis por um programa de isótopos desenvolvido pelo grupo de Tucker. Após várias pesquisas tornou-se claro que o ${ }^{99 \mathrm{~m}} \mathrm{Tc}$ possuía características físicas ideais para vários procedimentos de diagnóstico por imagem, detecção de doenças e para o estudo da estrutura e da função de órgãos, sendo especialmente útil por ser quimicamente incorporado em moléculas ligantes que se concentram em determinados órgãos ou tecidos quando injetadas no corpo (International Atomic Energy Agency, 2010). Este isótopo tem uma meia vida de cerca de 6 horas e emite fótons com energia de $140 \mathrm{keV}$ ao decair para ${ }^{99} \mathrm{Tc}$, um isótopo radioativo com cerca de 214.000 anos de meia vida, sendo esta energia do fóton ideal para a detecção eficaz por instrumentos de cintilografia, tais como câmera gama, cuja faixa de operação é entre 100 e 300 keV (Emsley, 2011). Os dados coletados pela câmera são analisados para produzir imagens estruturais e funcionais detalhadas (Nishiyama, 2012).

Hoje, 90\% dos procedimentos de diagnóstico são realizados com $0{ }^{99 m} \mathrm{Tc}$, cujas características físicas de decaimento são mostradas na Fig. 3 (Banerjee et al., 2001). 


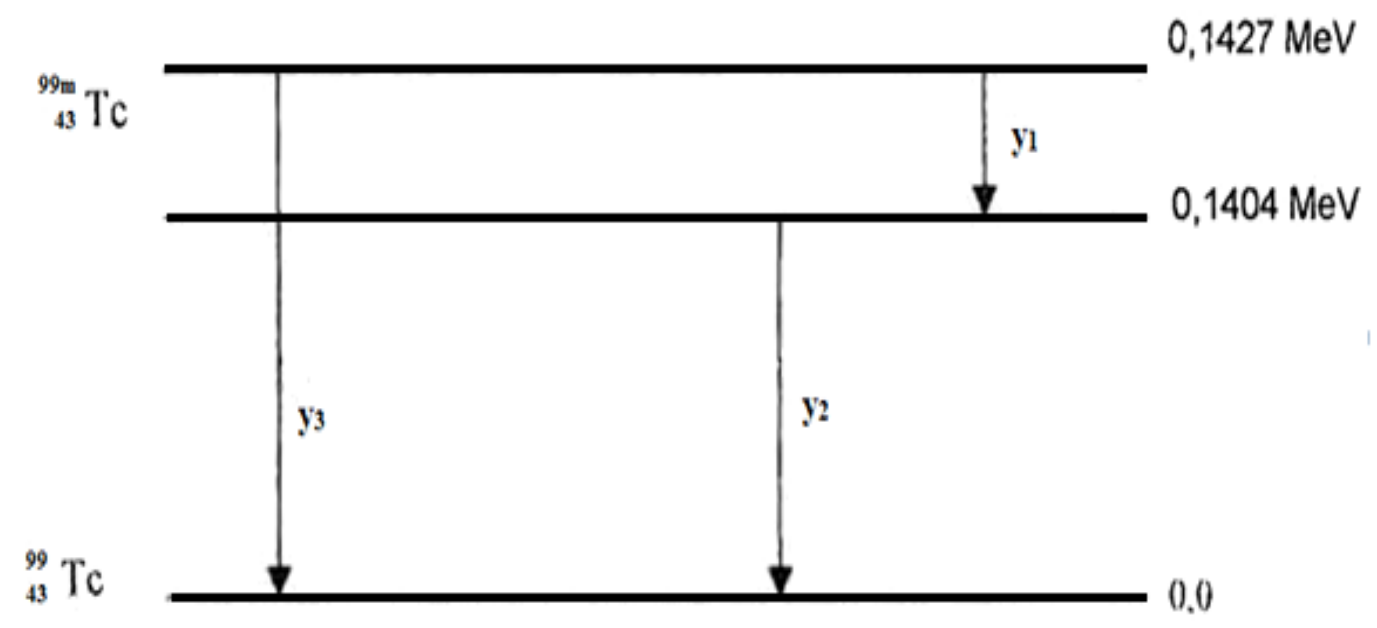

Figura 3. Esquema de decaimento do ${ }^{99 m} \mathrm{Tc}$ (Boyd, 1982).

Geralmente, o ${ }^{99 \mathrm{~m}} \mathrm{Tc}$ é produzido através de um processo de múltiplos passos, começando com a irradiação de alvos contendo ${ }^{235} \mathrm{U}$ em um reator nuclear. Esta irradiação faz com que ocorra a fissão do ${ }^{235} \mathrm{U}$ e a produção do ${ }^{99} \mathrm{Mo}$, e muitos outros isótopos médicos importantes tais como ${ }^{131} \mathrm{I}$ e ${ }^{133} \mathrm{Xe}$ (Nieto, 2004). Após a irradiação os alvos são processados quimicamente para separar o ${ }^{99} \mathrm{Mo}$ dos outros produtos de fissão. $\mathrm{O}{ }^{99} \mathrm{Mo}$ é então adsorvido em uma coluna de alumina $\left(\mathrm{Al}_{2} \mathrm{O}_{3}\right)$, sendo enviado para clínicas e hospitais em dispositivos blindados, conhecidos como geradores de tecnécio, conforme mostra a Fig. 4 (Ferreira et al, 2008).

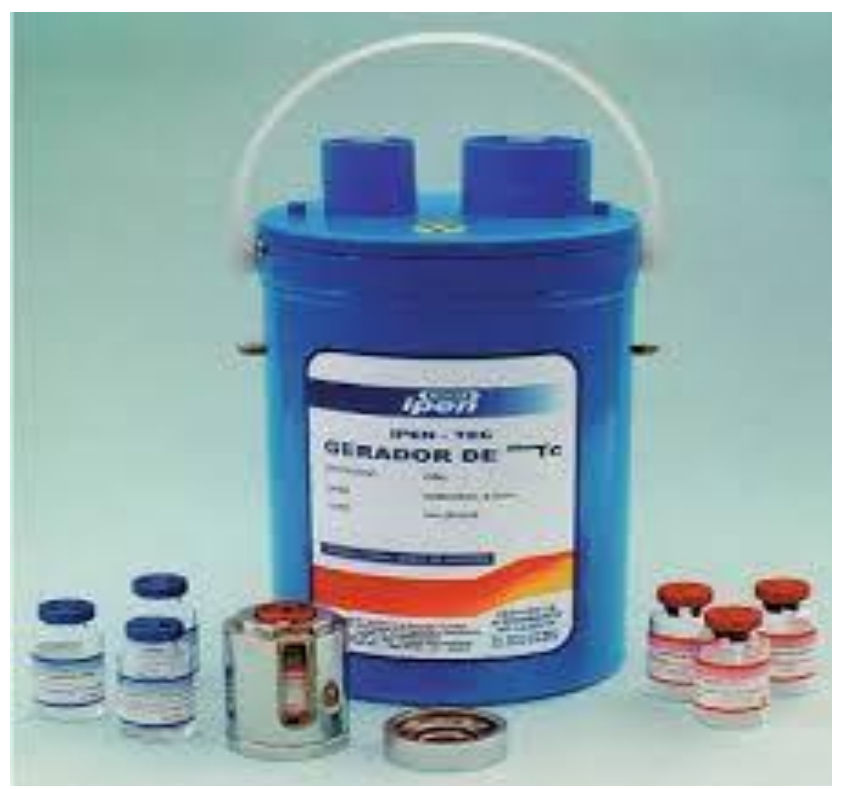

Figura 4. Gerador de tecnécio produzido pelo IPEN/CNEN-SP.

No sistema gerador, o ${ }^{99}$ Mo é retido, decai para o ${ }^{99 \mathrm{~m}} \mathrm{Tc}$, que é então 
separado com solução salina sob a forma de pertecnetato de sódio $\left(\mathrm{Na}^{99 \mathrm{~m}} \mathrm{TcO}_{4}\right)$. O gerador de tecnécio pode ser eluído várias vezes ao dia, durante cerca de uma semana, quando é necessário fazer sua substituição (Sameh, 1989).

Sabendo-se que o radioisótopo pai: molibdênio $99\left({ }^{99} \mathrm{Mo}\right)$ tem meia vida física de $66 \mathrm{~h}$ e que o radioisótopo filho: tecnécio-99m $\left({ }^{99 \mathrm{~m}} \mathrm{Tc}\right)$ tem meia vida física: 6:02 h, o ${ }^{99 \mathrm{~m}} \mathrm{Tc}$ pode ser utilizado a distâncias longas do centro produtor, não devendo ser estocado para uso. Para o decaimento do ${ }^{99}$ Mo para o ${ }^{99 \mathrm{~m}} \mathrm{Tc}$, conforme mostrado na Fig. 5, a atividade do ${ }^{99 \mathrm{~m}} \mathrm{Tc}$ nunca excederá a atividade do ${ }^{99} \mathrm{Mo}$, pois apenas $87,5 \%$ de desintegrações do ${ }^{99} \mathrm{Mo}$ resultam em ${ }^{99 \mathrm{~m}} \mathrm{TC}$.

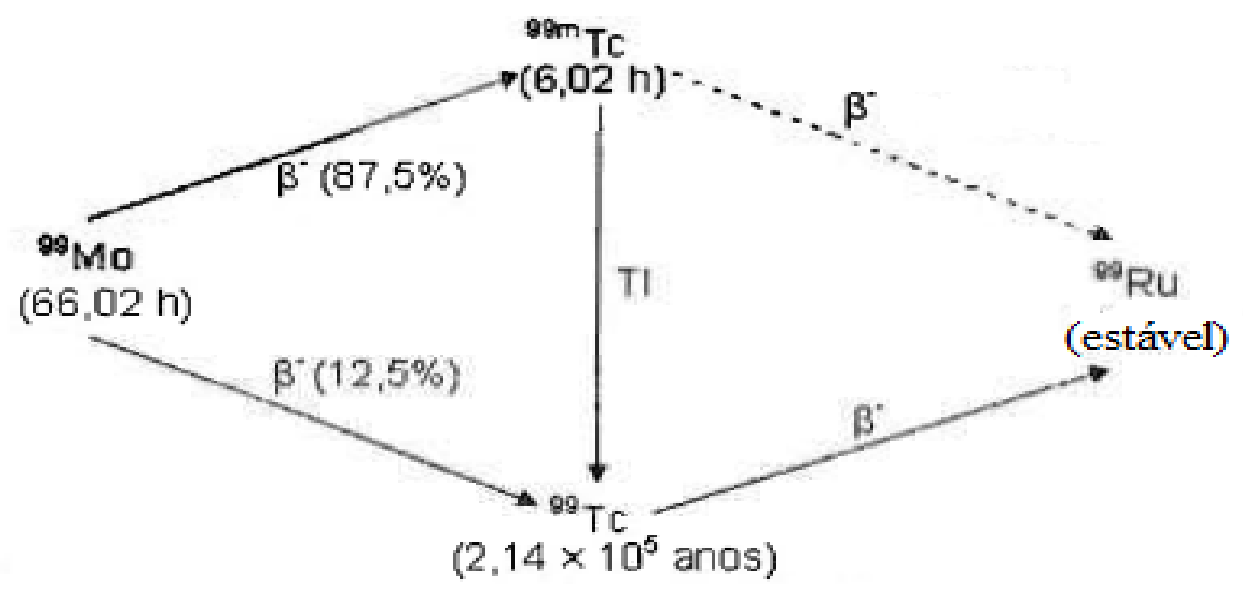

Figura 5. Esquema do decaimento radioativo do ${ }^{99} \mathrm{Mo}(\mathrm{TI}=$ transição isomérica) (Boyd, 1982).

\subsection{Produções do ${ }^{99}$ Mo em reatores nucleares}

O reator nuclear é visto como uma fonte de feixe de nêutrons para a área de produção de radioisótopos. A grande vantagem do uso de reator nuclear é a facilidade de irradiação, já que não é gerada grande quantidade de calor no alvo (Evans et al., 1987). Alvos utilizados para a produção do ${ }^{99}$ Mo são materiais que contém ${ }^{235} \mathrm{U}$ projetados para serem irradiados em um reator nuclear (Nishiyama, 2012) obedecendo alguns critérios:

- o tamanho do alvo deve ser adequado para se encaixar na posição de irradiação dentro do reator nuclear;

- o alvo deve conter uma quantidade suficiente de ${ }^{235} \mathrm{U}$ para assim poder produzir a quantidade requerida de ${ }^{99}$ Mo quando irradiado;

- o alvo deve apresentar boas propriedades de transferência de calor evitando assim o sobreaquecimento durante a irradiação.

- o alvo deve proporcionar uma barreira para impedir a liberação de produtos 
radioativos, em especial os gases de fissão, durante e após a irradiação;

- o material alvo deve ser compatível com os passos de processamento químico que serão utilizados para recuperar e purificar $0{ }^{99} \mathrm{Mo}$, após o alvo ser irradiado.

Tabela 1. Alvos de urânio utilizados para a produção do ${ }^{99} \mathrm{Mo}$ ou planejados para serem utilizados no futuro por diferentes produtores (Nishiyama, 2012).

\begin{tabular}{|c|c|c|}
\hline $\begin{array}{c}\text { Geometria do } \\
\text { Alvo }\end{array}$ & Material & Produtores \\
\hline Placas & $\begin{array}{c}\text { Ligas de U-Al ou dispersões } \\
\text { do tipo UAl }\end{array}$ & $\begin{array}{c}\text { Mallinckrodt, Institut National } \\
\text { dês Radioéléments, Nuclear } \\
\text { Technology Products, CNEA, } \\
\text { Australian Nuclear Science and } \\
\text { Technology Organisation } \\
\text { (ANSTO, OPAL reactor) }\end{array}$ \\
\hline Varetas (pin) & Ligas de U-Al & $\begin{array}{c}\text { MDS-Nordion (National } \\
\text { Research Universal reactor) }\end{array}$ \\
\hline Cilindros & $\begin{array}{c}\text { Filme fino de UO }{ }_{2} \text { envolvido } \\
\text { por dois tubos de aço inox }\end{array}$ & $\begin{array}{c}\text { Indonesian National Atomic } \\
\text { Energy Agency (BATAN), MDS- } \\
\text { Nordion (Maple reactors) }\end{array}$ \\
\hline
\end{tabular}

Os alvos metálicos são geralmente encapsulados (revestimento - cladding) em alumínio ou aço inoxidável para proteger o urânio metálico e as ligas das reações químicas externas e para manter os produtos do decaimento ocorrido durante o processo neutrônico do urânio físsel, conforme mostra a Fig. 6.

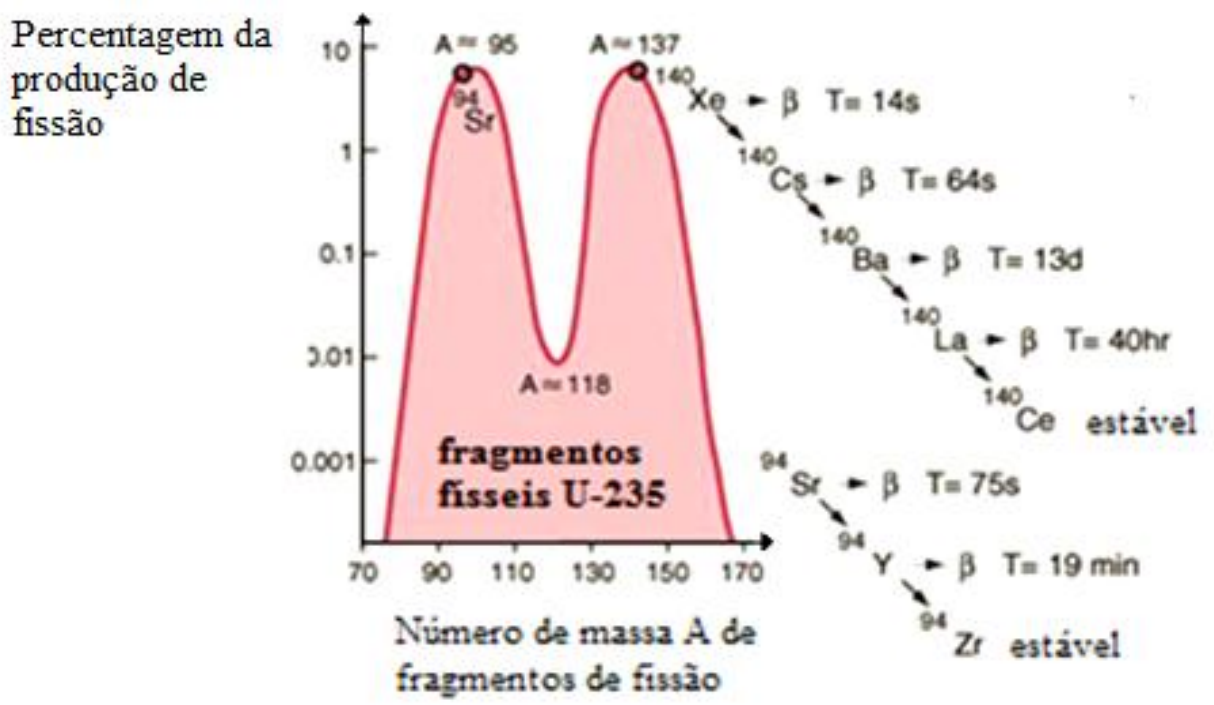

Figura 6. Rendimento de produção de fissão térmica versus número de massa (Takahashi, 2004). Adaptado.

Os alvos são irradiados com nêutrons térmicos sendo que alguns dos 
núcleos de ${ }^{235} \mathrm{U}$ absorvem estes nêutrons, que podem provocar a sua fissão. A fissão do núcleo produz dois ou até três núcleos de massa menor, conhecidos como fragmento de fissão. Cerca de $6 \%$ destes fragmentos de fissão são átomos de ${ }^{99} \mathrm{Mo}$ (Lamarsh, 1972). A quantidade de ${ }^{99} \mathrm{Mo} \mathrm{produzida} \mathrm{em} \mathrm{um} \mathrm{alvo} \mathrm{decorre} \mathrm{do}$ tempo de irradiação, da seção de choque de fissão térmica do ${ }^{235} \mathrm{U}$, do fluxo de nêutrons térmicos sobre o alvo, da massa de ${ }^{235} \mathrm{U}$ no alvo e da meia vida do ${ }^{99} \mathrm{Mo}$. Geralmente o fluxo de nêutrons térmicos nos reatores é da ordem de $10^{14}$ nêutrons $/ \mathrm{cm}^{2} . s$ e o tempo de irradiação necessário para atingir a máxima produção do ${ }^{99}$ Mo nos alvos são de 5 a 7 dias (National Research Council - NRC, 2009).

Tabela 2. Principais produtores de ${ }^{99}$ Mo utilizando alvos em reatores nucleares (Nishiyama, 2012).

\begin{tabular}{ccc}
\hline Produtor & País & \% suprimento mundial \\
\hline MDS - Nordion & Canadá & 40 \\
\hline Malinckrodt & Países Baixos & 25 \\
\hline IRE & Bélgica & 20 \\
\hline NTP & África do Sul & 10 \\
\hline Outros & Argentina, Austrália e Rússia & 5 \\
\hline
\end{tabular}

Em vista do interesse mundial na produção do ${ }^{99} \mathrm{Mo}$, a IAEA (International Atomic Energy Agency) a partir de 2004, desenvolveu um Projeto de Pesquisa Coordenado (CRP) para ajuda aos países interessados em iniciar uma produção doméstica em pequena escala de ${ }^{99} \mathrm{Mo}$ para atender a demanda local (Goldman et al., 2007) Os países interessados terão acesso à tecnologia e métodos de produção do 99Mo usando alvos de folhas finas de urânio metálico LEU, miniplacas LEU, ou pela ativação neutrônica (n, gama) (Vandegrift, 2005). O Brasil em 2009, através do IPEN/CNEN-SP iniciou sua participação neste projeto.

\subsection{Alvos do tipo LEU em uso na América do Sul}

\section{- Utilizado na Argentina}

A Comissão Nacional de Energia Atômica deste país utiliza alvos na forma 
de miniplacas de $U A I_{x}-A l$ revestidas com alumínio, irradiados no reator $R A 3$, com uma potência térmica de $5 \mathrm{MW}$ (atualmente $10 \mathrm{MW}$ ), moderado e refrigerado à água leve (Cristini et al, 2002). Os alvos tem um volume total de $6,825 \mathrm{~cm}^{3} \mathrm{com}$ $1,5 \mathrm{~mm}$ de espessura, $35 \mathrm{~mm}$ de largura e $130 \mathrm{~mm}$ de comprimento. O volume total do cerne de UAl $-\mathrm{Al}$ é de $2,415 \mathrm{~cm}^{3}$ com $0,7 \mathrm{~mm}$ de espessura, $30 \mathrm{~mm}$ de largura e $115 \mathrm{~mm}$ de comprimento (Fabro et al., 2005). A massa de urânio no alvo é de $1,4 \mathrm{~g}$, que para um volume de $2,415 \mathrm{~cm}^{3}$ fornece uma densidade de ${ }^{235} \mathrm{U}$ igual a $0,58 \mathrm{~g} \mathrm{de}{ }^{235} \mathrm{U} / \mathrm{cm}^{3}$. Considerando-se um enriquecimento de $19,9 \%$ em massa de ${ }^{235} \mathrm{U}$, a densidade do urânio no cerne do alvo é de $2,91 \mathrm{~g} \mathrm{U} / \mathrm{cm}^{3}$. Os alvos são irradiados durante 108-120 horas, com um fluxo de nêutrons de $1 \times 10^{14}$ $\mathrm{n} / \mathrm{cm}^{2}$.s e mantidos em resfriamento por 10 horas após a irradiação na piscina do reator. Desta forma a Argentina garante uma demanda semanal de $170 \mathrm{Ci}$ de ${ }^{99} \mathrm{Mo}$ (Cristini et al, 2002).

\section{- Utilizado no Chile}

A CCHEN, Comisión Chilena de Energía Nuclear estuda a utilização de alvos de folha fina de urânio metálico revestidas com uma camada de níquel. Estas folhas são colocadas entre dois tubos concêntricos de alumínio e irradiadas no reator $\mathrm{RECH}-01$, de potência térmica $5 \mathrm{MW}$, moderado e refrigerado à água leve com berílio como elemento refletor. A folha apresenta as dimensões de 50 $\mathrm{mm} \times 100 \mathrm{~mm}$ e $0,13 \mathrm{~mm}$ de espessura recoberta em ambos os lados por uma camada de 0,015 mm de níquel (Schrader et al., 2007) contendo $13 \mathrm{~g}$ de urânio enriquecido a 19,75\%, correspondendo a uma densidade de $20 \mathrm{~g}$ de $\mathrm{U} / \mathrm{cm}^{3}$ e uma massa de 2,57 g de ${ }^{235} \mathrm{U}$. Em um período de irradiação de 48 horas na potência máxima do reator, pode ser obtida uma atividade de $155 \mathrm{Ci}$ de ${ }^{99} \mathrm{Mo}$ ao final da irradiação (Schrader et al, 2008).

\subsection{Urânio}

O urânio é um elemento metálico radioativo pertencente à família dos actinídeos, encontrado em estado sólido a temperatura ambiente e sua descoberta é creditada ao cientista alemão Martin Heinrich Klaproth em 1789 (Katz et al, 1957). Foi o primeiro elemento no qual se detectou a propriedade da radioatividade, sendo este feito creditado a Antoine Henri Becquerel em 1896. 
Seu átomo possui o núcleo mais pesado que existe naturalmente na Terra: contém 92 prótons e 135 a 148 nêutrons. Quando puro, é um sólido, metálico e radioativo, muito duro e denso, de aspecto cinza a branco prateado, muito semelhante à coloração do níquel. Antes do advento da energia nuclear, o urânio possuía poucas aplicações. Era utilizado em fotografia e nas indústrias de cabedal (fabricação de peças de couro e sola) e de madeira. Os seus compostos eram empregados como corantes e fixadores de cor para a seda e a lã. No entanto, a aplicação mais importante do urânio é a energética. Para este fim, utilizam-se apenas três isótopos do elemento $\left({ }^{234} \mathrm{U},{ }^{235} \mathrm{U}\right.$ e $\left.{ }^{238} \mathrm{U}\right)$, com mecanismos de reação ligeiramente diferentes, embora o mais utilizado seja ${ }^{235} \mathrm{U}$.

A descoberta da fissão nuclear, por Hahn e Strassmann, no final de 1938 e reportada no início de 1939 (Shea, 1983) fez com que o urânio adquirisse uma posição de destaque no campo da energia nuclear. Muitos sistemas foram propostos para o uso da energia nuclear, geralmente envolvendo a fissão do isótopo ${ }^{235} \mathrm{U}$. Na produção de energia nuclear há uma reação de fissão autossustentada, que ocorre em um reator, normalmente imerso num tanque com uma substância moderadora e refrigerante - sendo o mais comum à água. $A$ água é aquecida e vaporizada pelo reator, passando em seguida por turbinas que acionam geradores, para assim produzir energia elétrica. Esse mecanismo é utilizado nos reatores de potência tipo "PWR" (reatores de água pressurizada), e empregam o urânio geralmente em forma cerâmica $\left(\mathrm{UO}_{2}\right.$, por exemplo). Os reatores nucleares de fissão podem ser bastante compactos, sendo utilizados na propulsão de submarinos, navios de combate e em algumas sondas espaciais como as dos programas das sondas Cassini-Huygens, Voyage e Pioneer, podendo utilizar outros radioisótopos como o ${ }^{239} \mathrm{Pu}$ em seus reatores de energia (Borges, 2011).

De acordo com as Indústrias Nucleares do Brasil (INB), o país ocupa a sexta posição no ranking mundial de reservas de urânio com aproximadamente 309 mil toneladas de $\mathrm{U}_{3} \mathrm{O}_{8}$. Devido às dimensões continentais brasileiras, apenas $1 / 3$ do território nacional foi submetido à pesquisa uranífera, com a implantação do Complexo Minero Industrial de Caetité para aproveitamento das jazidas da Província Uranífera de Lagoa Real (BA) e Itataia (CE) que produzem o pó do mineral, conhecido por yellow cake. O minério de urânio mais comum e importante é a uraninita, composta por uma mistura de $\mathrm{UO}_{2}$ com $\mathrm{U}_{3} \mathrm{O}_{8}$. Os países 
cujas reservas são maiores do que as brasileiras são pela ordem: Austrália, Canadá, Estados Unidos, África do Sul e Niger (Matos et al, 1999).

Tabela 3. Abundância natural dos isótopos de urânio (Lederer et al, 1978).

\begin{tabular}{cc}
\hline Número de massa & Abundância (átomos por cento) \\
\hline 234 & $0,0057 \pm 0,0002$ \\
\hline 235 & $0,7204 \pm 0,0007$ \\
\hline 238 & $99,2739 \pm 0,0007$ \\
\hline
\end{tabular}

$\mathrm{O}$ isótopo ${ }^{235} \mathrm{U}$ considerado como o de maior importância, existe na natureza com uma quantidade de $0,72 \%$. Esse isótopo pode realizar fissão nuclear com nêutrons lentos, liberando uma enorme quantidade de energia. A fissão completa do ${ }^{235} \mathrm{U}$ resulta em uma quantia de energia calorífica equivalente a $22.000 .000 \mathrm{~kW} / \mathrm{h}$ por $\mathrm{kg}$. Há vantagens na utilização do ${ }^{235} \mathrm{U}$ não apenas por gerar grandes quantidades de energia, mas também porque pode ser utilizado para a síntese de outros elementos actinídeos. O urânio com sua composição isotópica natural pode ser usado em reações em cadeia de larga escala para gerar nêutrons. A reação em cadeia é sustentada pelo excesso de nêutrons produzidos na fissão do ${ }^{235} \mathrm{U}$, enquanto os nêutrons excedentes daqueles que sustentam a reação em cadeia podem ser capturados pelo isótopo natural ${ }^{238} \mathrm{U}$ para produzir plutônio (Katz et al, 1957),

$$
\begin{aligned}
& { }_{92} \mathrm{U}^{235}+\mathrm{n} \rightarrow \text { produtos de fissão + energia }+2,5 \text { nêutrons } \\
& { }_{92} \mathrm{U}^{238}+\mathrm{n} \rightarrow{ }_{92} \mathrm{U}^{239} ;{ }_{92} \mathrm{U}^{239} \rightarrow \beta-\rightarrow \mathrm{Np}^{239} \rightarrow \beta-\rightarrow \mathrm{Pu}^{239}
\end{aligned}
$$

O isótopo abundante ${ }^{238} \mathrm{U}$ pode então ser convertido em ${ }^{239} \mathrm{Pu}$, que, assim como $\circ{ }^{235} \mathrm{U}$, também sofre fissão com nêutrons lentos. Um grande número de isótopos sintéticos de urânio pode ser obtido: 
Tabela 4. Isótopos do urânio (Katz et al, 1957).

\begin{tabular}{|c|c|c|c|}
\hline Isótopo & Meia- vida & Modo de desintegração* & Fonte \\
\hline $\mathrm{U}^{227}$ & 1,3 meses & $\alpha(6,8)$ & $\operatorname{Th}^{232}(\alpha, 9 n)$ \\
\hline $\mathrm{U}^{228}$ & 9,3 meses & $\alpha(80 \%)(6,67) ;$ C.E. $(20 \%)$ & $\operatorname{Th}^{232}(\alpha, 8 n)$ \\
\hline $\mathrm{U}^{229}$ & 58 meses & C.E.(80\%); a $(20 \%)(6,42)$ & $\operatorname{Th}^{232}(\alpha, 7 n)$ \\
\hline $\mathrm{U}^{230}$ & 20,8 dias & $\alpha(5,884 ; 5,813 ; 5,658)$ & $\mathrm{Pa}^{231}(\mathrm{~d}, 3 \mathrm{n})$ \\
\hline $\mathrm{U}^{231}$ & 4,2 dias & C.E. $(>99 \%) ; \alpha\left(6 \times 10^{-3} \%\right)(5,45)$ & $\mathrm{Pa}^{232}(\mathrm{~d}, 2 \mathrm{n})$ \\
\hline $\mathrm{U}^{232}$ & 73,6 anos & $\alpha(5,318 ; 5,261 ; 5,134)$ & $\operatorname{Th}^{232}(\alpha, 4 n)$ \\
\hline $\mathrm{U}^{233}$ & $1,62 \times 10^{5}$ anos & $\begin{array}{c}\alpha(4,816 ; 4,773 ; 4,717 ; 4,655 ; \\
4,582 ; 4,489)\end{array}$ & $\mathrm{Pa}^{233}$ (decaimento) \\
\hline $\mathrm{U}^{234}$ & $2,48 \times 10^{5}$ anos & $\alpha(4,77 ; 4,72)$ & natural \\
\hline $\mathrm{U}^{235}$ & $7,13 \times 10^{8}$ anos & $\alpha(4,58 ; 4,47 ; 4,40 ; 4,20)$ & natural \\
\hline$U^{236}$ & $2,39 \times 10^{7}$ anos & $\alpha(4,50)$ & $\mathrm{U}^{235}(\mathrm{n}, \mathrm{Y})$ \\
\hline $\mathrm{U}^{237}$ & 6,75 dias & $\beta^{-}(0,249 ; 0,084)$ & $U^{238}(d, p 2 n)$ \\
\hline $\mathrm{U}^{238}$ & $4,50 \times 10^{9}$ anos & $\alpha(4,18)$ & natural \\
\hline $\mathrm{U}^{239}$ & 23,5 meses & $\beta^{-}(1,22)$ & $U^{238}(n, Y)$ \\
\hline$U^{240}$ & 14,1 horas & $\beta^{-}(0,36)$ & $\mathrm{U}^{2}$ \\
\hline
\end{tabular}

${ }^{\star}$ Energia da radiação, em milhões de elétrons-Volt; $C E$ = Captura eletrônica.

O urânio na forma metálica é empregado em certos tipos de reatores, devendo estar isento de qualquer impureza absorvedora de nêutrons, como o boro, cádmio ou terras raras, assim como quantidades significativas de outros elementos. Os requisitos de pureza necessários para os contaminantes absorvedores de nêutrons são muito mais rigorosos que os padrões usuais para os demais metais. O urânio metálico pode ser obtido através de redução de haletos de urânio $\left(\mathrm{UCl}_{3}, \mathrm{UCl}_{4}, \mathrm{UF}_{4}\right)$ com metais eletropositivos ( $\mathrm{Na}, \mathrm{Li}, \mathrm{Ba}, \mathrm{Mg}$ ) (Impe, 1954). A redução dos haletos de urânio leva a produtos de reação com pontos de fusão relativamente baixos quando comparados com a redução dos compostos óxidos de urânio que apresentam maiores pontos de fusão. A redução de haletos é em geral preferível, já que o metal obtido em forma mais massiva é melhor de se manusear do que em forma mais segregada, devido a sua reatividade. 
Tabela 5. Propriedade física e química do urânio (Katz et al, 1957).

\begin{tabular}{cc}
\hline Propriedade & Valor \\
\hline Ponto de fusão & $1132 \pm 1 \mathrm{C}$ \\
\hline Pressão de vapor $(1630-1970 \mathrm{~K})$ & $\log \mathrm{P}_{\mathrm{mm}}=-2330 / \mathrm{T}+8,583$ \\
\hline Ponto de ebulição & $3818^{\circ} \mathrm{C}$ \\
\hline Densidade $\left(25^{\circ} \mathrm{C}\right)$ & $19,4 \mathrm{~g} / \mathrm{cm}^{3}$ \\
\hline Ponto de mudança de fase & $668^{\circ} \mathrm{C}$ \\
\hline$\alpha \rightarrow \beta$ & $774^{\circ} \mathrm{C}$ \\
\hline$\beta \rightarrow Y$ & $4,7 \mathrm{kcal} / \mathrm{mol}$ \\
\hline Calor de fusão & $106,7 \mathrm{kcal} / \mathrm{mol}$ \\
\hline Calor de vaporização & $116,6 \mathrm{kcal} / \mathrm{mol}$ \\
\hline Calor de sublimação $(0 \mathrm{~K})$ & $1521,4 \mathrm{cal} / \mathrm{mol}$ \\
\hline Entalpia $\left(25^{\circ} \mathrm{C}\right)$ & $6,612 \mathrm{cal} /{ }^{\circ} \mathrm{C} . \mathrm{mol}$ \\
\hline Capacidade térmica $\left(25^{\circ} \mathrm{C}\right)$ & $11,99 \pm 0,02 \mathrm{cal} /{ }^{\circ} \mathrm{C} . \mathrm{mol}$ \\
\hline Entropia $\left(25^{\circ} \mathrm{C}\right)$ & $0,071 \mathrm{cal} / \mathrm{cm} . \mathrm{s} .{ }^{\circ} \mathrm{C}$ \\
\hline Condutividade térmica $\left(70{ }^{\circ} \mathrm{C}\right)$ & $2,4 \times 10^{4}(\mathrm{ohm} . \mathrm{cm})^{-1}$ \\
\hline Condutividade elétrica &
\end{tabular}

Tabela 6. Propriedades mecânicas do urânio (Katz et al, 1957).

\begin{tabular}{cc}
\hline Propriedade & Valor \\
\hline Módulo de elasticidade (psi) & $25,5 \times 10^{6}$ \\
\hline Módulo de Poisson & 0,20 \\
\hline Módulo de cisalhamento (psi) & $10,6 \times 10^{6}$ \\
\hline Módulo de carga (psi) & $14,2 \times 10^{5}$ \\
\hline Módulo de resiliência (lbs/m $\left.{ }^{3}\right)$ & 0,176 \\
\hline Limite proporcional (psi) & 3.000 \\
\hline Tensão resultante (psi) & 27.000 \\
\hline $0,1 \%$ offset & 33.000 \\
\hline $0,2 \%$ offset
\end{tabular}


A dureza do urânio é bastante afetada pela presença de impurezas e na condição como fundido ela pode variar entre $200 \mathrm{HB}$ e $220 \mathrm{HB}$. O trabalho a frio pode aumentar sua dureza em valores acima de $385 \mathrm{HB}$, porém, acima de 200 ${ }^{\circ} \mathrm{C}$, sua dureza diminui acentuadamente. $\mathrm{O}$ urânio em sua fase gama é tão "macio" que torna sua fabricação dificultosa, enquanto a fase beta é mais dura e consideravelmente mais frágil que a fase alfa (Katz et al, 1957).

O urânio metálico puro tem sido produzido em larga escala nos Estados Unidos através da redução de $U_{4} F_{4}$ por magnésio desde 1943. Um programa de redução de urânio por magnesiotermia com massas acima de $5 \mathrm{~kg}$ foi desenvolvido no Reino Unido na década de 1950. A França opera em Bouchet, desde a mesma década, um processo de redução de tetrafluoreto de urânio com o cálcio (Borges, 2011).

Desde 1962 o Instituto de Pesquisas Energéticas e Nucleares/Comissão Nacional de Energia Nuclear - São Paulo (IPEN/CNEN-SP), vem se preocupando com a produção de urânio metálico nuclearmente puro (Ferreto, 1999). A partir de 1977 teve início um meticuloso programa envolvendo a obtenção de dados experimentais para permitir o conhecimento e aprimoramento dos procedimentos, para produção do urânio metálico e suas ligas (Lima, 1992 - Relatório MU - № 04/92). O IPEN desenvolveu seu próprio sistema reator-cadinho para a redução de $\mathrm{UF}_{4}$ por $\mathrm{Mg}$. Na redução, (magnesiotermia) a reação exotérmica é representada pela seguinte equação:

$$
\mathrm{UF}_{4}+2 \mathrm{Mg} \rightarrow \mathrm{U}+2 \mathrm{MgF}_{2} \quad(\Delta \mathrm{H} 298=83,5 \mathrm{kcal})
$$

A continuidade no desenvolvimento do processo para a produção do urânio metálico levou o IPEN, em 1988, à obtenção de dingotes de urânio, pela primeira vez no país. Esses se constituem em peças metálicas com geometria predeterminada e própria para conformação plástica, obtidas diretamente por redução, sem passar por refino e fundição sob vácuo. A plasticidade e a pureza deste material permite que o país utilize dingotes para fins nucleares, industriais e em aplicações na área médica (Lima, 1992 - Relatório MU - № 03/92). 


\subsection{Níquel}

O níquel é um dos metais mais importantes e versáteis da indústria. É um elemento de liga essencial em ferros fundidos, aços e ligas não ferrosas, com característica de metal branco-prateado, dúctil, maleável, dureza escala de Mohs 3,5. O sistema de cristalização é isométrico. $O$ níquel também se destaca pela sua relativa resistência a oxidação e corrosão, sendo mais duro que o ferro.

Atualmente, existem no Brasil três distritos produtores de níquel, cujo produto final é tanto o níquel eletrolítico com teor de pureza de 99,9\% de níquel, como a liga ferro-níquel com teor oscilando entre $20 \%$ e $40 \%$ (Andrade, 2000). A Tab. 7 fornece algumas propriedades do níquel.

O níquel é amplamente utilizado na produção de aços inoxidáveis e ligas especiais. Também é aplicado na fabricação de baterias recarregáveis, reações de catálise, moedas, revestimentos metálicos e fundição. $O$ uso do níquel é considerado crescente em diversos setores da indústria, onde se destaca na informática, aeronáutica e energia, especialmente a nuclear.

Tabela 7. Propriedades atômicas e físicas do níquel (Deyoung et al, 1985)

\begin{tabular}{ll}
\hline Massa atômica u & 58,68 \\
\hline Número atômico & 28 \\
\hline Massa específica $\mathrm{g} / \mathrm{cm}^{3}$ & 8,9 \\
\hline Temperatura de fusão ${ }^{\circ} \mathrm{C}$ & 1455 \\
\hline Temperatura de ebulição ${ }^{\circ} \mathrm{C}$ & 2913 \\
\hline Condutividade elétrica $\mathrm{S} . \mathrm{m} / \mathrm{mm}^{2}$ & 10,41 \\
\hline Condutividade térmica $\mathrm{W} /(\mathrm{m} . \mathrm{K})$ & 91,2 \\
\hline Módulo de Young $(\mathrm{GPa})$ & 207 \\
\hline Dureza $(\mathrm{HV})$ & 64 \\
\hline Estrutura cristalina & $\mathrm{CFC}$ \\
\hline
\end{tabular}

A Fig. 7 compara a resistência à corrosão versus pH de três diferentes tipos de metais duros: WC-Co, WC-Ni e TiC-Ni. Ambos os materiais que contém níquel apresentam resistência à corrosão superior (ASM, 2000). 


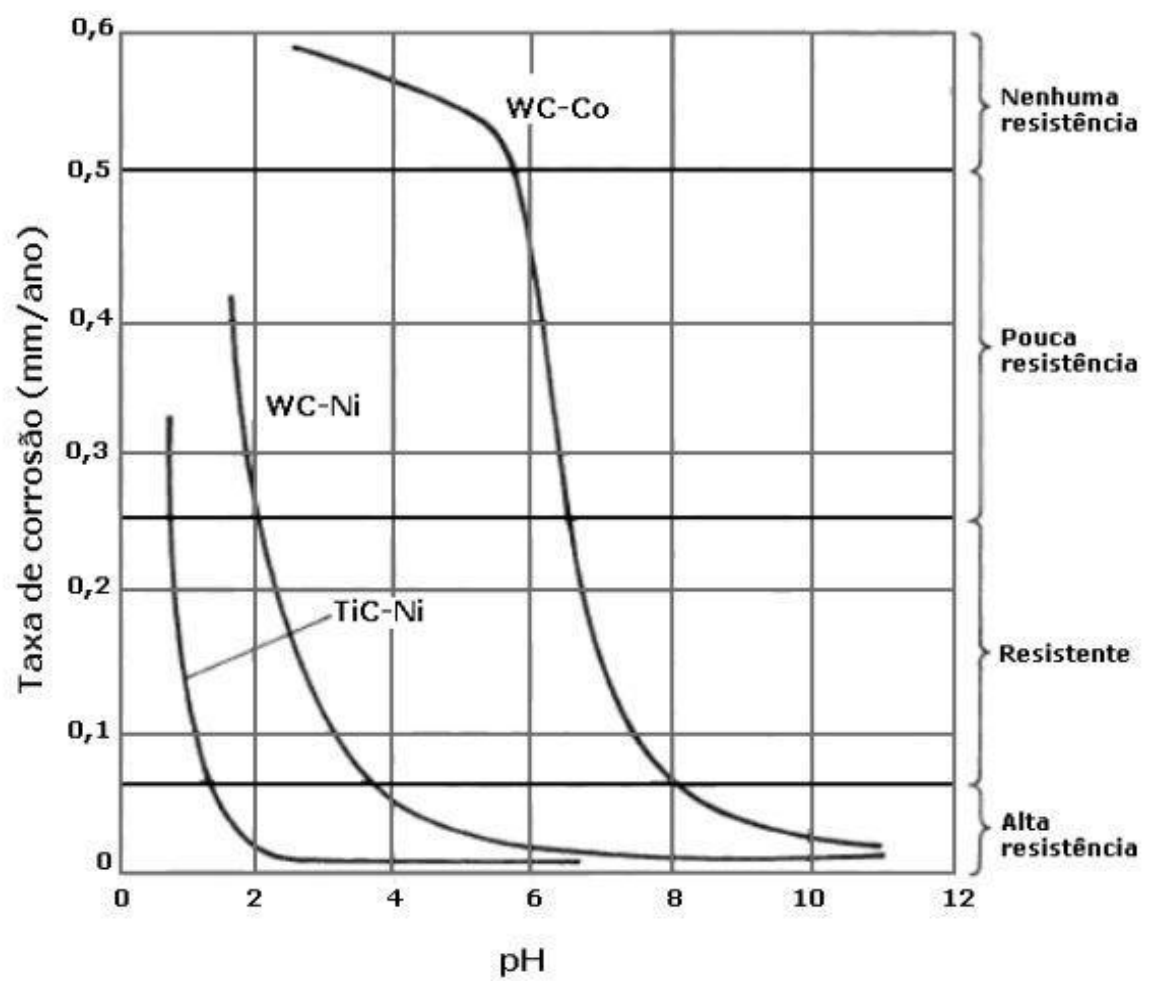

Figura 7. Efeito do níquel na resistência a corrosão de alguns metais duros (ASM, 2000).

\subsection{Cobre}

Além de ser um importante ativador em um processo de sinterização por fase sólida, também é adicionado com o objetivo de melhorar a condutividade térmica do componente e sua usinabilidade, na medida em que, preenchendo os poros do material, elimina o efeito de corte intermitente ou interrompido preservando e aumentando a vida da ferramenta de corte (Greetham, 1990).

\subsection{Diagramas de fases}

Os materiais, mesmo quando substâncias puras, podem existir sob várias formas. Suas propriedades dependem significativamente da natureza, número e quantidade das possíveis formas diferentes em que se apresentam. Por isso, é importante conhecer em que condições esses materiais assumirão as suas várias formas. Referentes a um grande número de materiais que exigiam e exigem informações deste tipo, em 1876, J. Willard Gibbs, deduziu pela primeira vez a regra das fases. Essas informações são habitualmente reunidas em mapas, como funções da temperatura, pressão e composição, em condições de equilíbrio. Este 
gráfico foi definido como diagrama de equilíbrio de fases, ou simplesmente diagrama de fases (Segadães, 1987).

Assim, o diagrama de fases é um método eficiente de predizer quais fases se encontram em equilíbrio para uma dada composição de liga a uma determinada temperatura. Também pode-se determinar a composição química de cada fase e calcular a quantidade de cada fase presente. $O$ fenômeno de fusão e solidificação para um só elemento, metal puro, é feito a uma temperatura constante chamada ponto de fusão. Para a mistura de metais com outros elementos, metais ou metalóides, a liga começa a fundir a certa temperatura e passa inteiramente ao estado líquido a uma temperatura mais elevada ou, inversamente, do estado líquido ao estado sólido a uma temperatura mais baixa. Entre estas duas temperaturas a liga forma uma massa pastosa, constituída de um metal líquido e de cristais sólidos, cujas proporções variam em função da temperatura (Almeida, 2009), vide Fig. 8.

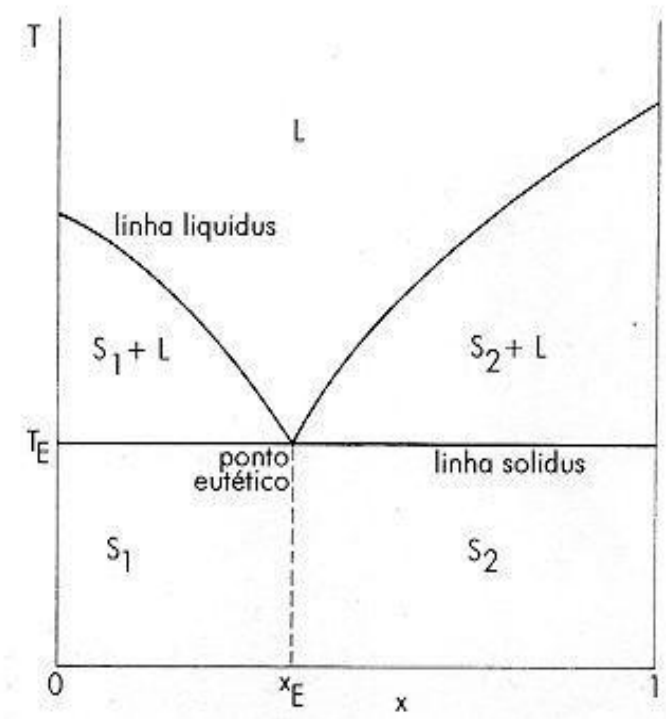

Figura 8. Representação esquemática do equilíbrio $S / L$ para um sistema do tipo eutético (Almeida, 2009).

Neste diagrama pode-se observar a existência de duas linhas: a liquidus e a solidus. A linha liquidus é a linha acima da qual todo o sistema se encontra no estado líquido, e a linha solidus é a linha abaixo da qual só existe sólido. Nesta Fig. 8 existe o chamado ponto eutético, onde a fase líquida está em equilíbrio com a fase sólida. A temperatura eutética é a temperatura mais baixa à qual pode existir líquido. $\mathrm{O}$ diagrama de fases da liga $\mathrm{Ni}-\mathrm{U}$ pode ser visualizado na Fig. 9 a 
seguir.

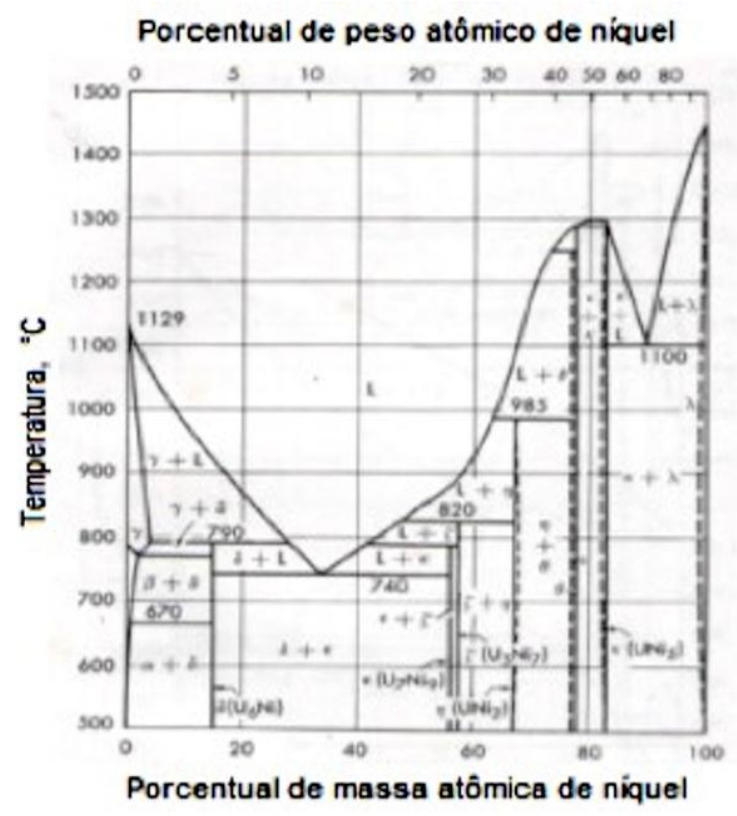

Figura 9. Diagrama de fases níquel - urânio (Chakrabarti et al, 1990).

O níquel em presença de urânio a $740{ }^{\circ} \mathrm{C}$ forma um eutético, uma reação isotérmica reversível, em que uma solução líquida é convertida em duas ou mais misturas sólidas intimamente ligadas com o arrefecimento. O diagrama de fases das ligas cobre - urânio e níquel - cobre, podem ser visualizados nas Figs. 10 e 11.

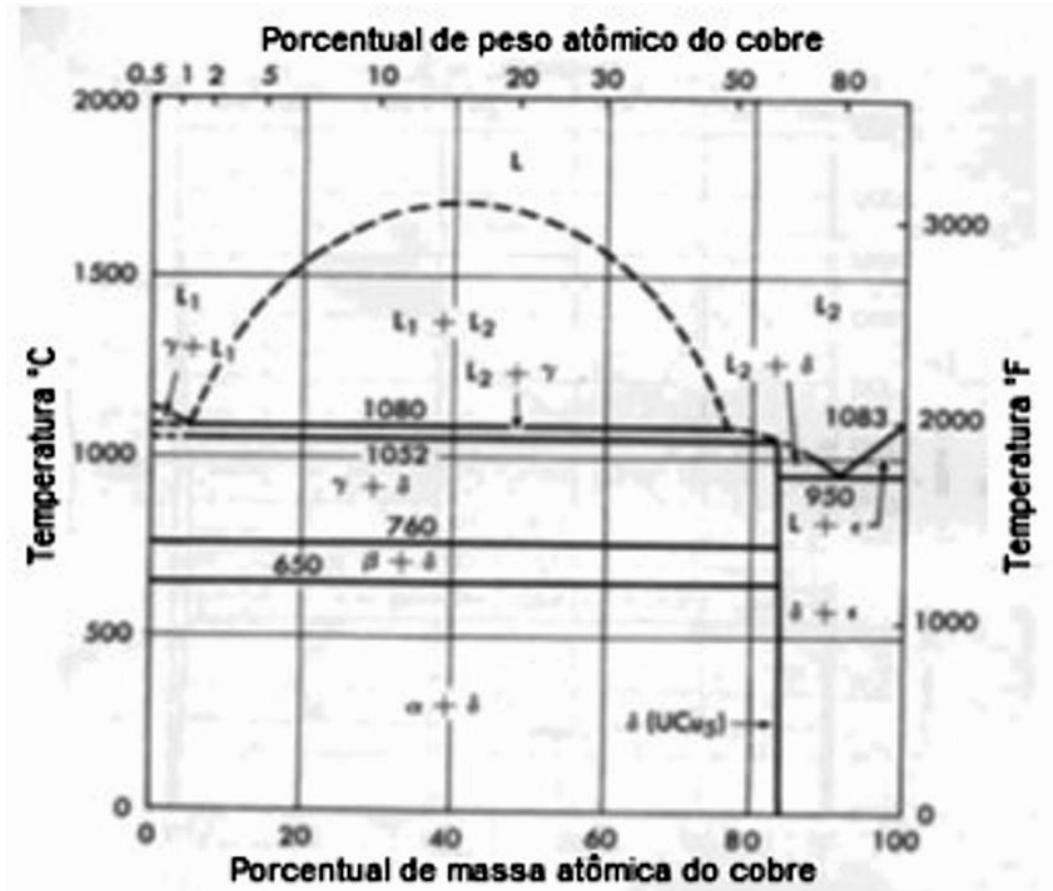


Figura 10. Diagrama de fases cobre - urânio (Chakrabarti et al, 1990).

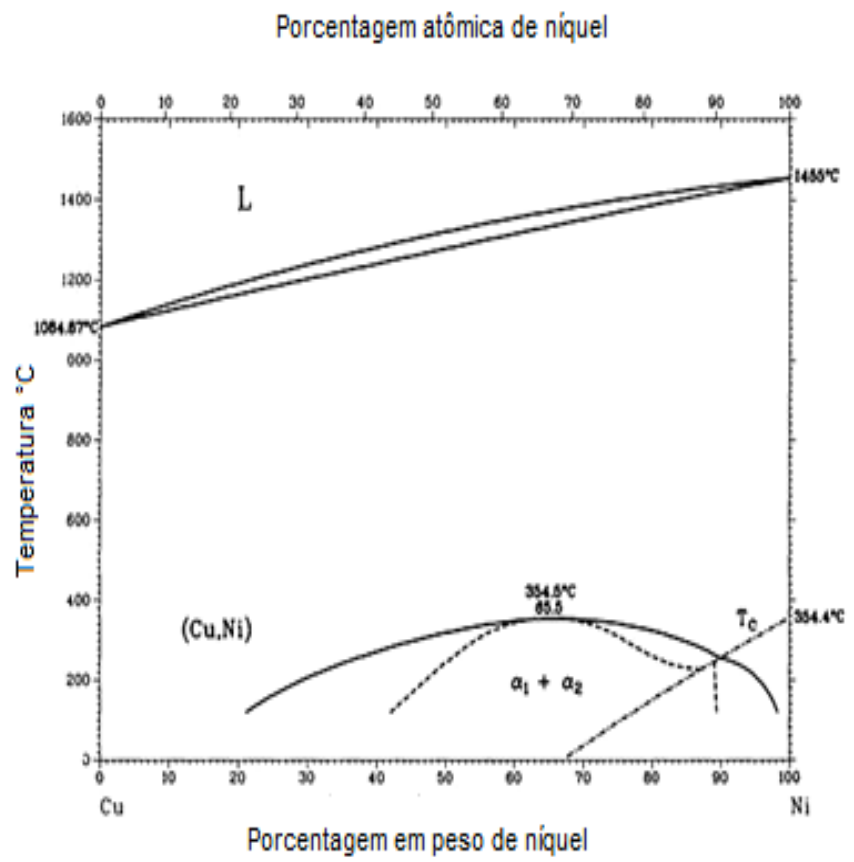

Figura 11. Diagrama de fases no sistema Cu-Ni (Chakrabarti et al, 1990).

As fases de equilíbrio no sistema de Cu-Ni estão na fase líquida, $L$, e na fase (Cu-Ni). A fase líquida é miscível em todas as proporções e é estável até o ponto de fusão do $\mathrm{Cu}$ em $1084,87^{\circ} \mathrm{C}$.

\subsection{Metalurgia do pó}

As origens das técnicas da metalurgia do pó M/P confundem-se com os primórdios da civilização humana. O uso de pós-metálicos tem sido atribuído a várias partes do mundo. $O$ interesse inicial em metalurgia do pó cresceu de uma base material em expansão, formando os elementos comuns, como o cobre e o ferro, levando a uma nova tecnologia de menor custo (German,1984). Mais recentemente, a metalurgia do pó tem sido associada a melhor qualidade, homogeneidade e produtividade. Fatores econômicos como o número reduzido de operações na produção da peça acabada, em relação a outros processos e o aproveitamento quase total da matéria prima, contribuem para que atualmente a metalurgia do pó venha sendo utilizada em larga escala. A expansão do processamento $\mathrm{M} / \mathrm{P}$ em áreas que exigem materiais de alta qualidade $\mathrm{e}$ propriedades únicas irá criar ainda mais oportunidades no futuro.

Na metalurgia do pó, um pó é definido como um sólido finamente dividido, 
menor do que $1 \mathrm{~mm}$, na sua dimensão máxima. Na maioria dos casos, os pós irão ser metálicos, embora possam ser combinados com outras fases tais como cerâmicos ou polímeros. A possibilidade já mencionada da MP poder combinar materiais metálicos com não metálicos propiciou o desenvolvimento dos cermets, uma combinação de cerâmica com metal, que busca associar a boa ductilidade, alta resistência mecânica e alta condutividade térmica dos metais ao alto ponto de fusão e resistência à oxidação das cerâmicas (Goetzel, 1984; Loberto, 2012).

Uma característica importante de um pó é a sua área superficial relativamente elevada em relação ao volume. As partículas apresentam um comportamento intermediário entre a de um sólido e a de um líquido. São compressíveis como um gás, mas a compressão de um pó de metal é essencialmente irreversível, como a deformação plástica de um metal. Assim, um pó de metal é facilmente moldado, com o desejável comportamento de um sólido após a transformação.

As decisões relativas ao tipo de pó e sua fabricação influenciam a facilidade de compactação e sinterização. O microscópio eletrônico de varredura é uma das melhores ferramentas disponíveis para a observação das características distintas de pós-metálicos. Quando se tratar de pós, não só as propriedades das partículas individuais, mas também as propriedades coletivas (a granel) de um pó do lote devem ser estudadas. As propriedades de uma única partícula incluem o tamanho, forma, composição química, microestrutura, densidade e dureza (Chiaverini, 2001). O tamanho de uma partícula depende da técnica de medição, do parâmetro específico a ser medido, e da forma da partícula. Quase todos os materiais encontrados na engenharia podem ser transformados em formas de partículas.

O gráfico (vide Fig. 12) a seguir, faz um comparativo entre o consumo de material e a energia necessária para a produção de $1 \mathrm{~kg}$ de produto acabado em diversos processos.

A metalurgia do pó é considerada um processo de conservação de energia, pois praticamente mais de $94 \%$ da matéria prima inicial, permanece após a peça acabada, levando grande vantagem nesse sentido, com relação a outros processos (Thümmler et al, 1993).

O processo é eficaz em termos de custo, pois produz peças simples ou complexas, nas medidas finais ou próximas destas, com taxas de produção que 
podem atingir centenas ou até milhares de peças por hora, sendo também considerada uma alternativa econômica com menor impacto ambiental.

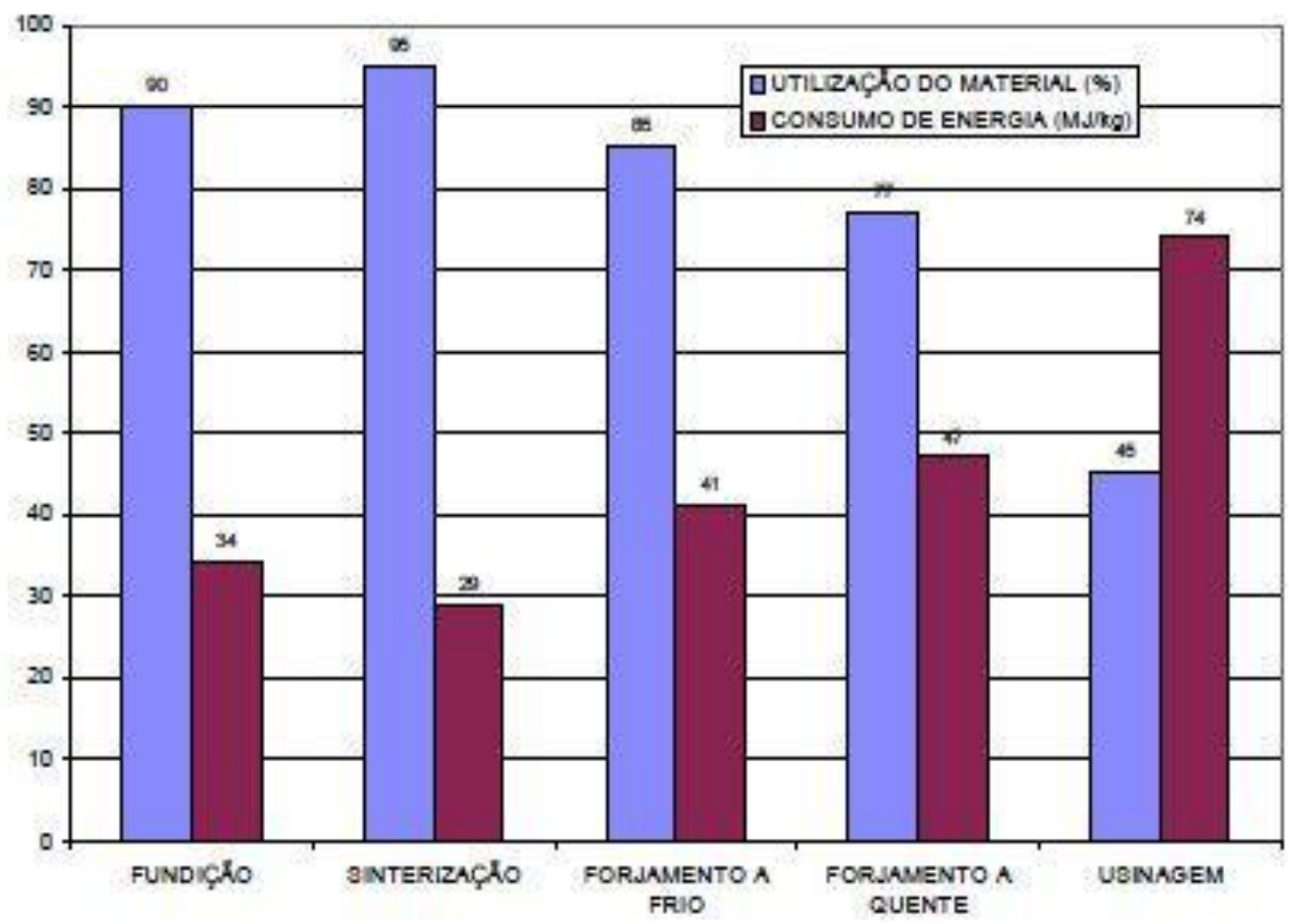

Figura 12. Consumo de material e energia necessária para produzir $1 \mathrm{~kg}$ do produto acabado (Zapata, 1987).

Basicamente são três as etapas fundamentais que compõem o processo da metalurgia do pó, a partir dos pós-metálicos obtidos por intermédio de várias técnicas, da moldagem ou compactação e do aquecimento ou sinterização.

Alguns autores, como Chiaverini (2001) e German (1984), mostraram que há vantagens e também algumas limitações no emprego do processo de metalurgia do pó. O diagrama mostrado na Fig. 13 mostra um fluxograma com etapas encontradas no processo.

\section{Algumas vantagens observadas:}

- elimina ou minimiza a necessidade de usinagem ou acabamento;

- elimina ou minimiza perdas através de refugos;

- mantêm tolerâncias dimensionais estreitas;

- permite a utilização de ampla variedade de ligas;

- produz bom acabamento superficial da peça;

- os produtos podem ser tratados termicamente para aumentar a resistência 
mecânica ou a resistência ao desgaste da peça;

Metalurgia do pó - fluxograma do processo

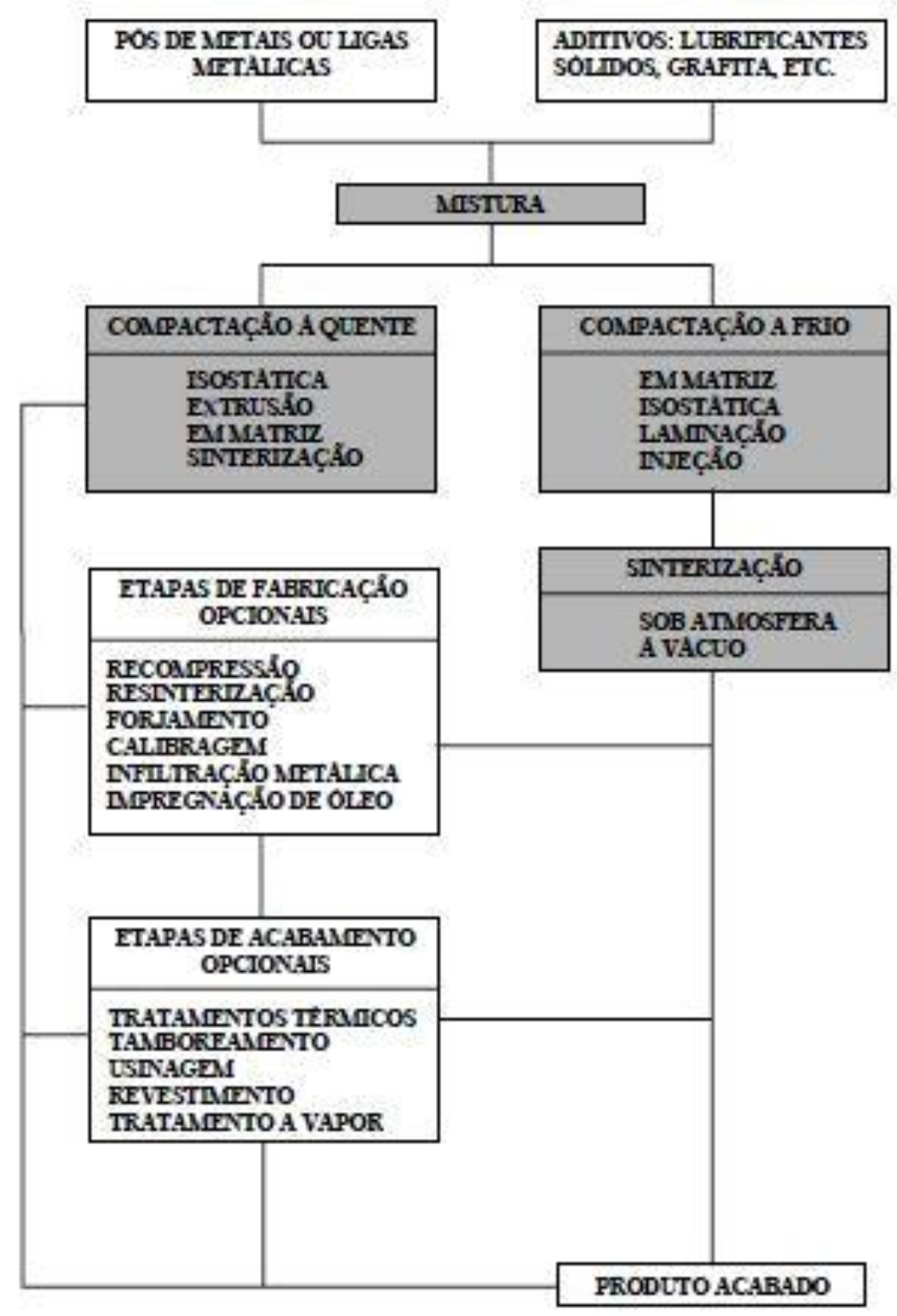

Figura 13. Representação esquemática das várias etapas do processo de metalurgia do pó, com destaque para as etapas fundamentais (Chiaverini, 2001).

- permite controlar a porosidade para aplicações auto-lubrificantes ou filtragem;

- permite a fabricação de peças de formas complexa, que por outros processos seriam praticamente impossíveis de se obter;

- resulta em produtos com bom desempenho e vida útil longa em aplicações críticas;

- permite o controle preciso dos materiais e suas propriedades, na medida em que se tem domínio dos pós-utilizados, garantindo melhor uniformidade dos produtos, 
minimizando impurezas e segregações, tensões internas, bolhas de gases e outros defeitos;

- podem ser obtidos produtos a partir de praticamente qualquer metal, liga, mistura ou materiais pré-ligados, bem como a inclusão de carbonetos ou outros materiais muito duros ou frágeis.

\section{Desvantagens ou limitações no emprego do processo:}

- alto custo inicial do ferramental, obrigando a execução de grandes lotes de produção para tornar o processo economicamente viável;

- apresenta algumas limitações de forma da matriz, para possibilitar a extração da peça;

- o tamanho e peso da peça são fatores limitantes, uma vez que são necessárias prensas maiores para compactação;

- possibilidade de contaminação dos pós ao longo das etapas de processamento.

\subsubsection{Produção do pó (métodos básicos)}

A produção de pós-metálicos é influenciada pelos requisitos de: consolidação, aplicação dos produtos e custo de fabricação. Saber como um pó é feito fornece uma boa base para estimar e entender algumas de suas características. Os métodos que podem ser utilizados na produção são: a trituração mecânica (moagem), reações químicas e decomposição, atomização do metal líquido (gás, água e centrífuga).

Os vários métodos de obtenção de pós-metálicos conduzem a diversas formas, tamanhos, distribuição e outras características do pó (Chiaverini, 2001) podendo ser agrupados em:

- Reações químicas e decomposição;

- Atomização de metais fundidos;

- Deposição eletrolítica;

- Processamento mecânico de materiais sólidos.

No grupo das reações químicas, o método mais comum é a redução de óxidos metálicos, pelo emprego de um agente redutor gasoso ou sólido (carbono). Os metais mais comumente produzidos na forma de pó por esse processo são o 
tungstênio, o molibdênio, o cobre e o ferro. Basicamente, qualquer óxido de ferro pode ser empregado como matéria prima para fabricar o pó de ferro, inclusive a "casca de óxido" ou "carepa" da laminação.

A decomposição térmica é outro processo que faz parte do grupo de reações químicas e consiste na obtenção de partículas de pó através da combinação de decomposição de vapor e condensação. Parte-se geralmente de compostos gasosos, resultando em partículas sólidas muito finas. Esses compostos são denominados carbonilas. Os principais pós-metálicos obtidos pelo processo de decomposição térmica, são o ferro e o níquel (Jesus Filho, 2006).

O processo de atomização é visto com grande importância devido ao fato de o mesmo poder ser empregado para praticamente qualquer metal ou liga que possa ser fundido, além do fato de poder-se produzir pós de metais com qualquer teor de pureza. Este processo consiste em forçar-se a passagem do metal liquefeito através de um pequeno orifício, na saída do qual a corrente líquida é desintegrada por um jato de ar, vácuo ou gás inerte. O metal solidifica imediatamente pela ação combinada do jato de gás e do resfriamento natural causado pela expansão do metal ao deixar o bocal e o pó resultante é recolhido numa câmara, mediante um sistema de sucção.

Dependendo do método para desintegrar a corrente de metal líquido, o processo de atomização pode ser dividido em: atomização em água; e atomização a gás. Em qualquer um dos casos, o equipamento essencial consiste nos seguintes componentes: forno de fusão, panela para conter o metal líquido, bocal ou válvula de vazamento, câmara de atomização e secador do metal líquido.

\section{Atomização em água}

Esse processo é limitado a metais e ligas que não se oxidem excessivamente pela ação da água ou metais e ligas cujos óxidos sejam facilmente reduzidos posteriormente.

Na Fig. 14 pode-se observar uma panela que atua como reservatório de metal líquido de modo a suprir um fluxo uniforme, contínuo e controlado de metal à válvula de vazamento, localizada na parte inferior da panela. Essa válvula controla a forma e o tamanho da corrente de metal líquido. Essa corrente é atingida pelo meio atomizador através de um sistema de válvulas e é 
desintegrada. Isto forma em consequência da alta velocidade do meio atomizante, diminutas gotas de metal, as quais se resfriam rapidamente, solidificando e depositando no fundo da câmara de atomização. Essa câmara pode eventualmente ser protegida com um gás inerte, o que reduz ou impede a oxidação do pó. (Klar et al, 1984).

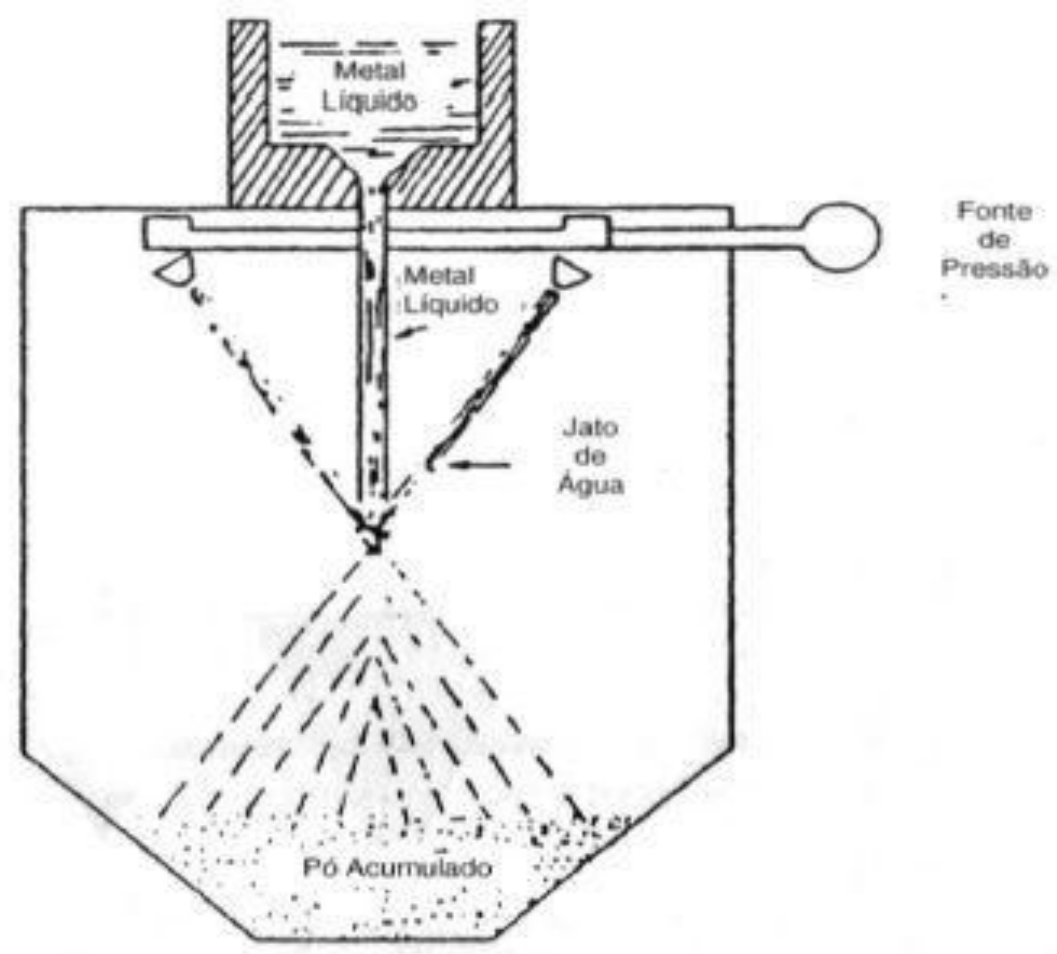

Figura 14. Representação esquemática do processo de atomização em água (Chiaverini, 2001).

\section{Atomização a gás}

Este processo utiliza como elemento atomizador do metal líquido, uma substância gasosa, como ar, argônio, hélio entre outros.

A imagem da Fig. 15 mostra o processo de atomização a gás com duas configurações possíveis. A velocidade do gás depende da forma do bocal de atomização e pode variar de $20 \mathrm{~m} / \mathrm{s}$ a velocidades supersônicas. Os pós-obtidos neste tipo de atomização podem variar sua estrutura entre amorfa, cristalina fina e dendrítica (o mesmo se aplica na atomização a água).

A principal característica que diferencia o pó atomizado de outros métodos de obtenção é o seu formato e densidade. Pode-se dizer que estes pós são livres de porosidade interna e que são relativamente compactos, com alta densidade 
batida e baixa área de superfície quando comparados com os outros tipos de pós, o que implica diretamente em boa escoabilidade, boa compressibilidade e baixa sinterabilidade (Klar et al, 1984).

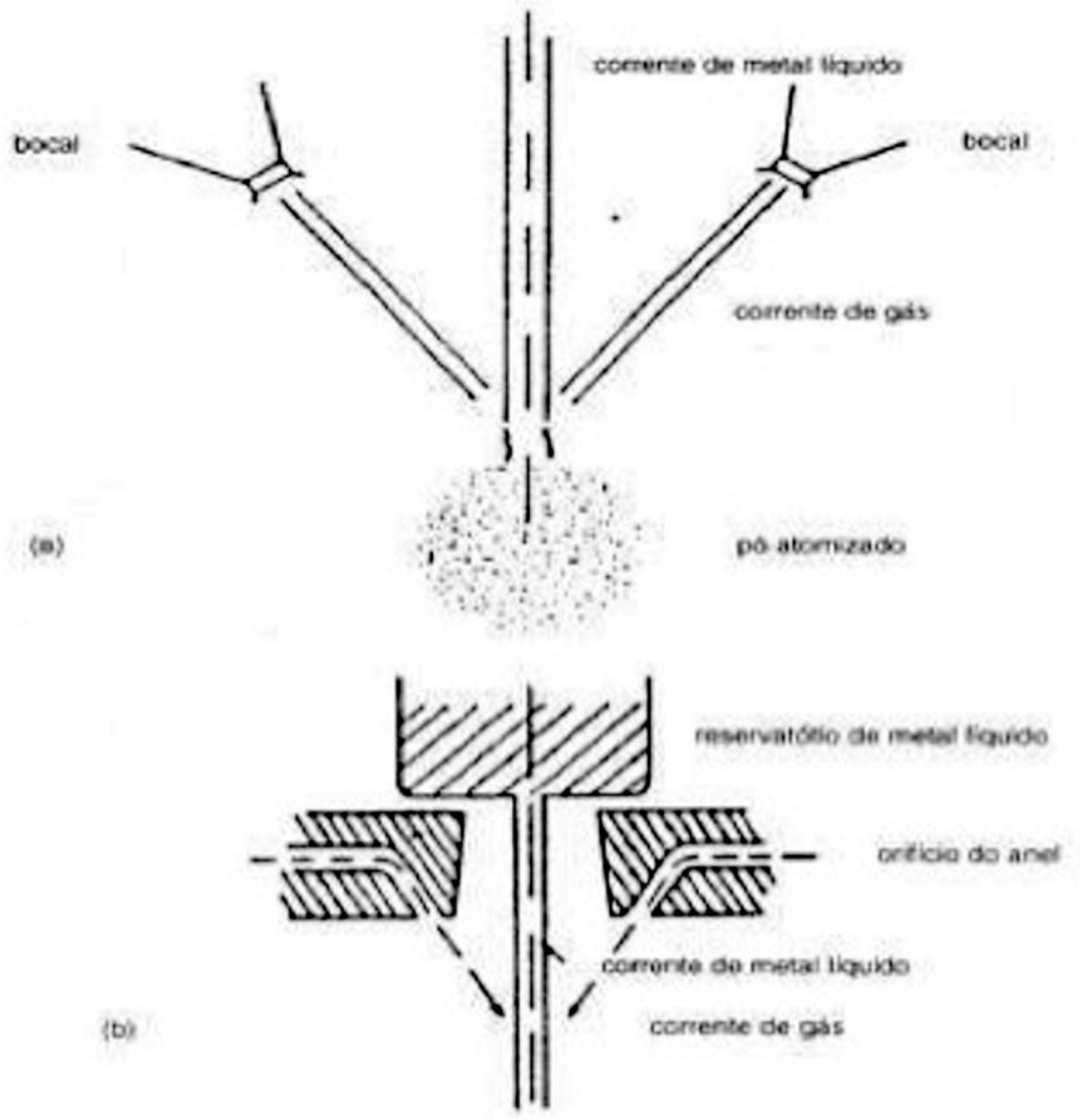

Figura 15. Representação esquemática do processo de atomização a gás: (a) configuração de dois jatos e (b) configuração "anel anular" (Chiaverini, 2001).

\section{Deposição eletrolítica}

O processo de deposição eletrolítica emprega soluções metálicas e sais fundidos e o metal é precipitado no catodo da célula eletrolítica, quer na forma de pó, quer em forma que possa ser facilmente desintegrada mecanicamente. Os metais que se prestam a esse processo são o ferro, o cobre, o níquel, o zinco, o cádmio, o estanho, o bismuto, a prata e o chumbo, sendo os pós de cobre, de berílio e de ferro os mais comumente fabricados.

\section{Cominuição mecânica}

Os processos mecânicos são fundamentalmente caracterizados por quatro mecanismos de fragmentação ou moagem:

- impacto; 
- atrito;

- cisalhamento;

- compressão

Cada um desses processos irá imprimir nos pós-obtidos, características e propriedades bastante particulares, sendo que na etapa de seleção dos pós, para uma determinada aplicação, é muito importante que se conheça os processos de obtenção dos pós com detalhes (Jesus Filho, 2006).

\subsubsection{Formato dos pós e suas características}

As características e os formatos dos pós estão intrinsecamente relacionados ao processo de fabricação empregado, sendo caracterizados por três tipos de propriedades.

Propriedades metalúrgicas:

- pureza e composição química;

- microestrutura da partícula;

- microdureza.

Propriedades geométricas:

- tamanho da partícula e distribuição granulométrica;

- formato externo da partícula;

- estrutura interna da partícula (porosidade).

Propriedades físicas/mecânicas:

- escoamento;

- densidade aparente;

- compressibilidade, resistência a verde, pressão de extração.

Muitas das propriedades inter-relacionam entre si, como por exemplo:

- microestrutura e microdureza dependem da composição química;

- pós com a microdureza mais elevada tem a compressibilidade reduzida;

- pós-grossos com partículas de geometria regular escoam melhor que pós finos e geometria irregular;

- pós com partícula de geometria irregular possuem mais alta resistência verde que pós cuja partícula tem geometria regular.

O formato externo da partícula é normalmente analisado por métodos de microscopia óptica. Existe vários modos possíveis de se expressar a medida do tamanho da partícula. A Fig. 16 mostra vários formatos de pós possíveis de serem 
obtidos.

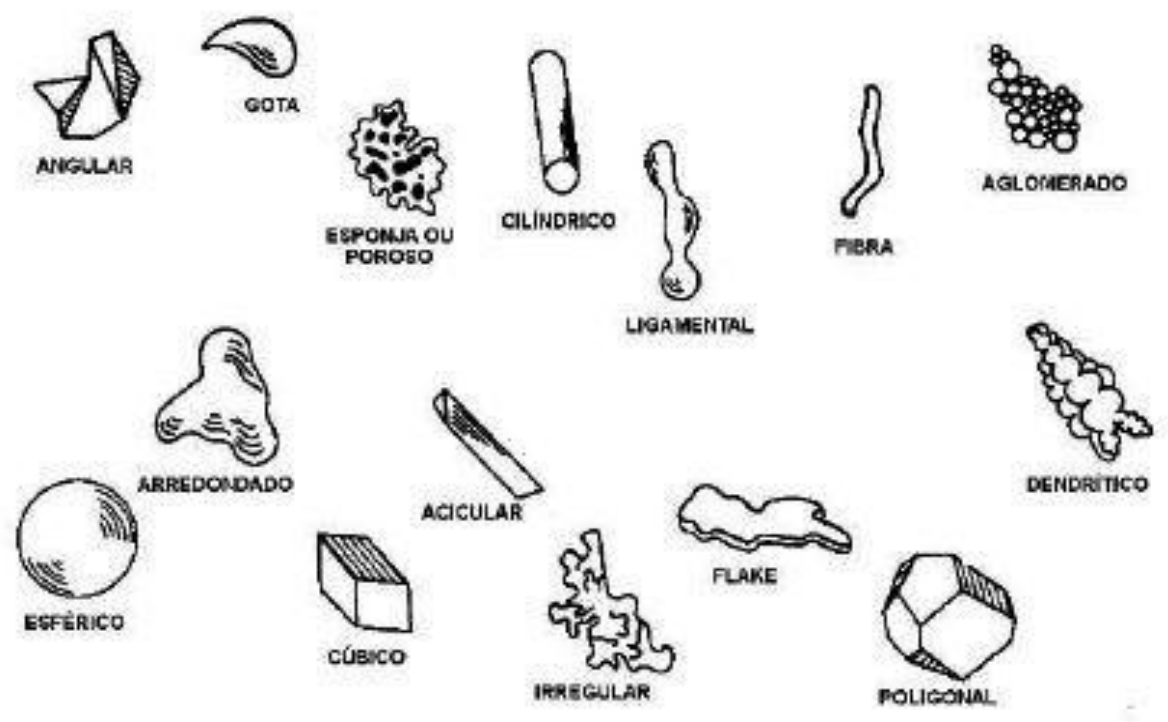

Figura 16. Coleção de possíveis formas de partículas (German, 1984).

O tamanho médio das partículas influencia algumas características do produto final, interferindo de maneira significativa em várias etapas de produção (transporte, compactação, sinterização, etc.) e na microestrutura do material, afetando a resistência mecânica, a densidade e as propriedades térmicas e elétricas de produtos acabados (lacocca et al, 1997). Uma partícula maior permite maior compactação, enquanto uma menor permite uma superfície com menor rugosidade. A Fig. 17 mostra possíveis medidas do tamanho de partícula (Allen, 1997).

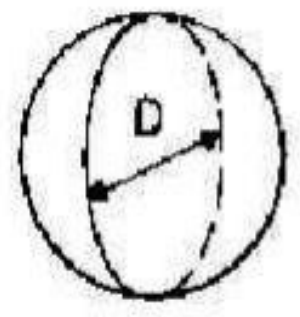

a) esfera

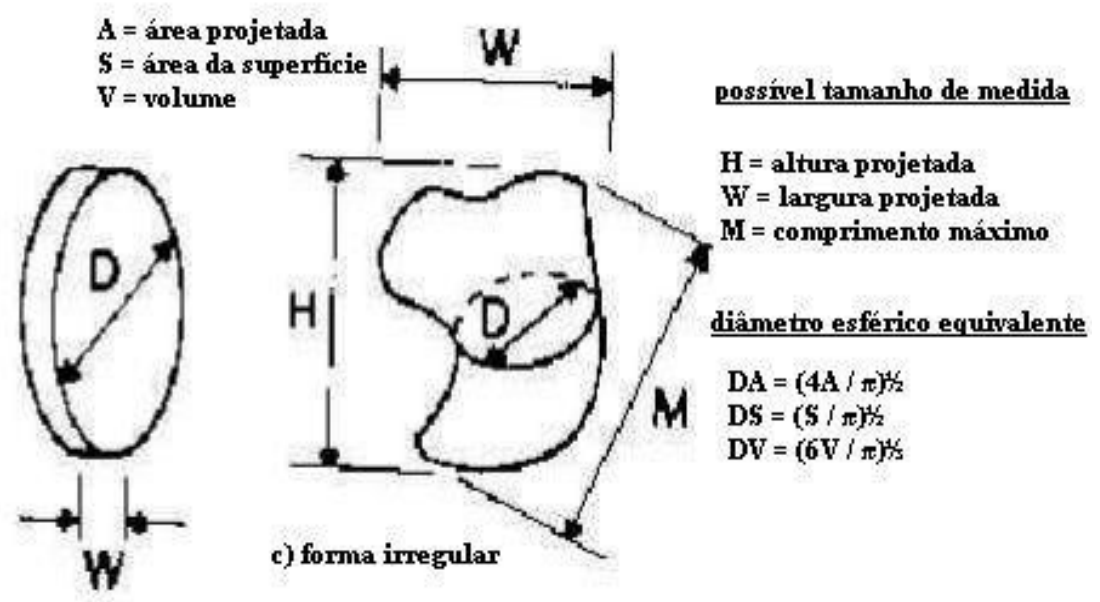

b) floco

Figura 17. Seis possíveis medidas do tamanho de partícula (Allen, 1997). 
A estrutura interna da partícula possui correlação direta com a porosidade, sendo que os poros, quando presentes, afetam não só as outras características dos pós, como densidade aparente e compressibilidade, como igualmente a porosidade da peça acabada. Devem-se distinguir dois tipos de porosidade: porosidade tipo esponjosa, caracterizada pela presença de poros que não estão interligados entre si e porosidade em que os poros estão interligados. Neste caso e quando, além disso, os poros estiverem ligados com a superfície, verifica-se um aumento da superfície específica das partículas, além de ficar facilitada a adsorção de gases durante seu processamento (Hirschhorn, 1969).

A rigor, qualquer sólido apresenta um grau de porosidade, detectável ou não, resultante da presença de cavidades, canais ou interstícios. A porosidade de um material exerce influência sobre suas propriedades físicas, tais como: densidade, condutividade térmica e resistência mecânica. Os poros podem ser classificados como abertos ou fechados, segundo a sua disponibilidade a um fluido externo. Os poros fechados são inativos quanto ao fluxo de líquidos e gases, mas exerce influência sobre as propriedades mecânicas, a densidade e a condutividade térmica. Os poros também podem ser interconectados. (Metallum, 2009).

Outra maneira de classificação dos poros é de acordo com sua forma conforme mostra a Fig. 18. A rugosidade da superfície (g) também pode ser considerada como porosidade.

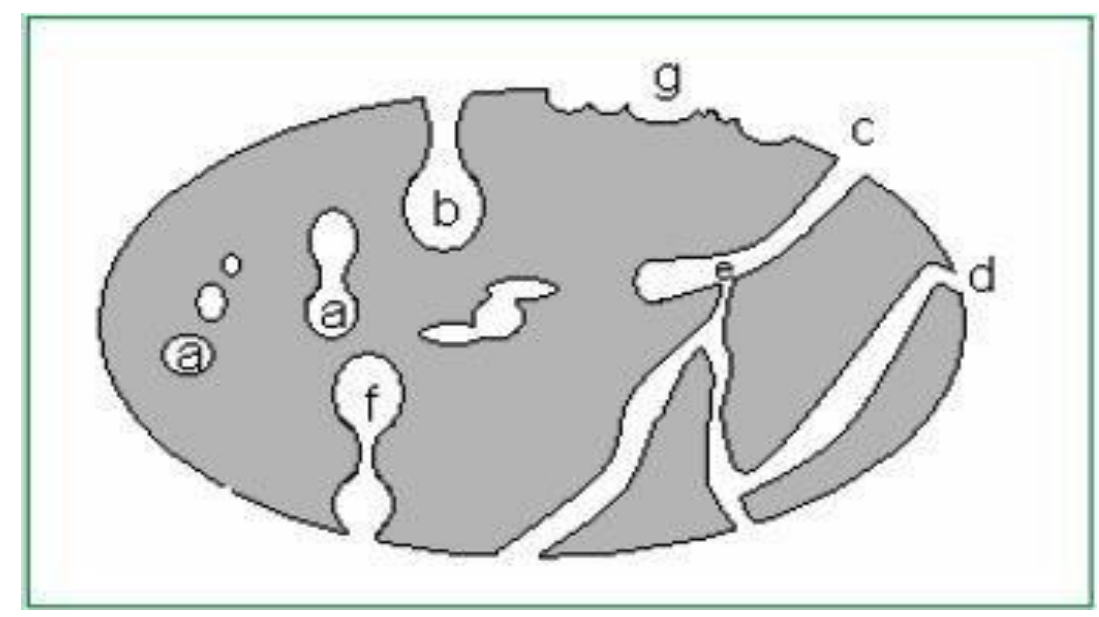

Figura 18. Representação dos diferentes tipos de poro: (a) fechados, (b) gargalo e garrafa, (c) cilíndricos, (d) afunilados, (e) interconectados, (f) irregulares. A letra (g) representa a rugosidade da superfície (Rouquerol, 1994). 
A escoabilidade é uma propriedade mecânica dos pós-metálicos que influencia diretamente a produtividade dos equipamentos de compactação. $O$ escoamento é basicamente influenciado pelo tipo de lubrificante misturado aos pós-metálicos, ao formato geométrico externo da partícula e a distribuição granulométrica dos pós-envolvidos.

A densidade aparente dos pós-metálicos influencia diretamente 0 preenchimento requerido da cavidade da matriz com pó a fim de se atingir a densidade requerida para o componente apenas compactado. Assim como no escoamento a densidade aparente tem seu valor influenciado pelo tipo e quantidade de lubrificante adicionado ao pó metálico.

A compressibilidade é uma expressão utilizada para quantificar a densificação que uma massa de pó pode sofrer sob aplicação de pressão. Definese ainda como a relação entre a "densidade verde", ou seja, a densidade do compactado apenas comprimido para a "densidade aparente" do pó. Em outras palavras, a compressibilidade corresponde a uma medida do decréscimo de volume que se obtém na operação de compactação. A compressibilidade do pó é uma propriedade inerente a cada material, sendo um método bem usado no controle de qualidade e de produção do pó metálico por meio de construção de curvas de compressibilidade (Smith et al, 1998).

\subsubsection{Mistura dos componentes}

A mistura adequada dos componentes, na proporção desejada, é essencial para finalizar uma peça após a sinterização, dentro das propriedades mecânicas desejadas. A mistura uniforme proporciona uma microestrutura homogênea ao final do processo, podendo ser adicionado à mistura um lubrificante, com a função de diminuir o atrito entre partículas da mistura e também das partículas com a parede do molde durante a compactação. Tanto a operação de homogeneização como de mistura propriamente dita, são realizadas no mesmo tipo de equipamento, que se caracteriza geralmente por apresentar a forma de duplo cone, conhecido como misturador em "V" ou em " $Y$ ". Utilizam-se igualmente tambores cilíndricos rotativos, horizontais ou inclinados.

O tempo de mistura é muito importante, pois um tempo muito longo pode levar a resultados até mesmo contrários aos desejados, tais como segregação de algum componente devido a diferenças de densidades, aglomeração de pó 
quando presente um aglomerante e outros inconvenientes e um tempo muito curto pode resultar em mistura imperfeita.

\subsubsection{Moldagem ou compactação}

A compactação de peças é responsável pela definição da geometria do componente e densificação da mistura de pós. As matrizes empregadas têm o formato do produto final desejado, sendo que a cavidade da matriz corresponde normalmente à forma e dimensões do produto final. A Fig. 19 descreve o comportamento dos pós, quando submetidos à compressão. No estágio inicial, com a introdução de força mecânica, ocorre um rearranjo das partículas soltas, para um denso empacotamento, havendo uma deformação nos pontos de contato com o aumento da força mecânica. Finalmente as partículas sofrem ampla deformação plástica (Chiaverini, 2001).

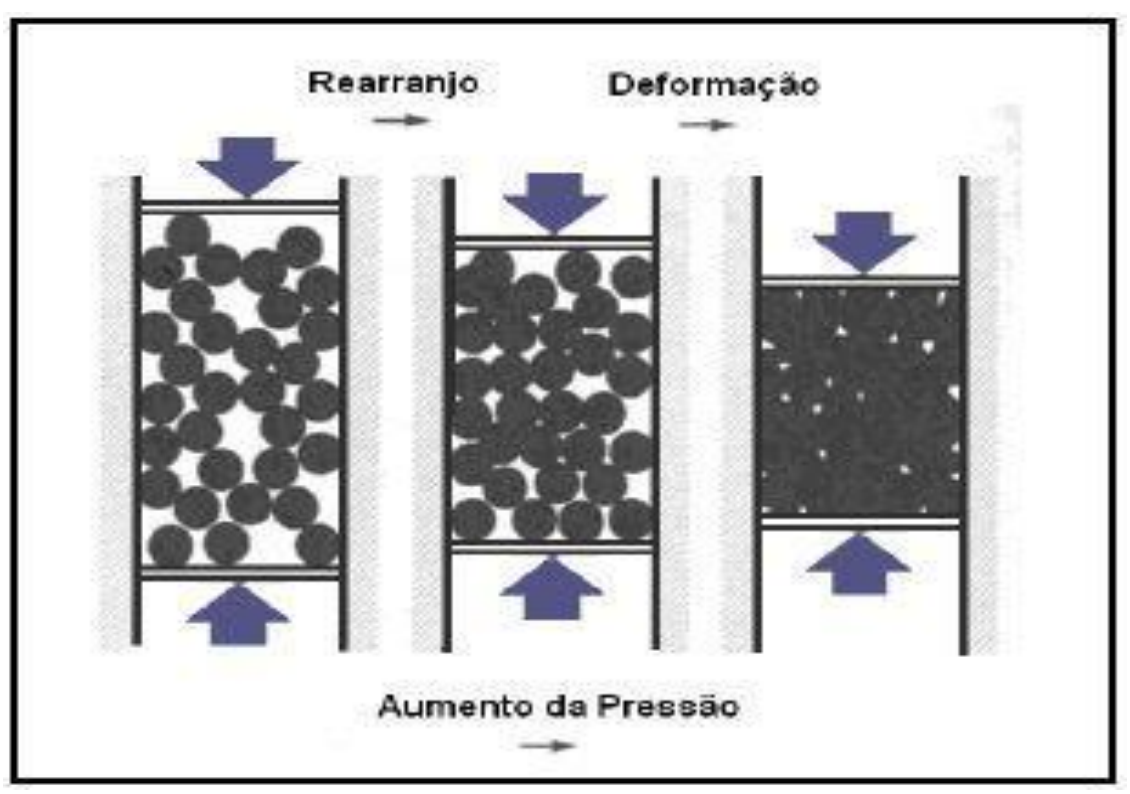

Figura 19. Estágios da movimentação das partículas na cavidade de uma matriz durante o processo de compactação (German, 1984).

Após a compactação é obtido um compactado denominado de corpo verde, que possui densidade chamada de densidade verde cujo valor obtido depende da pressão aplicada e da compressibilidade dos pós. A densidade e a resistência passam a ser duas características de grande importância nesta etapa, pois podem influenciar nas propriedades mecânicas da peça final. A Fig. 20 mostra um desenho esquemático de uma ferramenta para compactação e obtenção de 
material à verde (German, 1984).

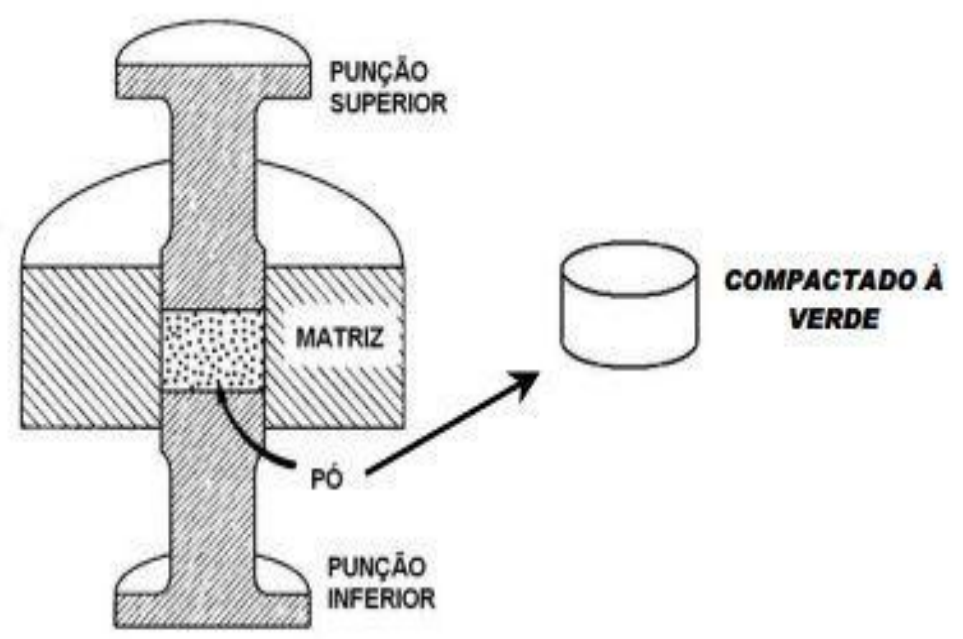

Figura 20. Desenho esquemático de uma ferramenta para compactação e obtenção do material à verde (German, 1984).

A principal variável que afeta a compactação é a compressibilidade do pó, que pode ser definida como a extensão segundo a qual uma massa de pó pode ser densificada pela aplicação de pressão. A compressibilidade é uma característica importante, pois determina a pressão a ser exercida pelo ferramental para se conseguir uma determinada densidade da peça. A conformação do pó pode ser realizada de várias maneiras:

- O método conhecido como "compactação uniaxial" que, para conformar o pó, se utiliza de um ferramental rígido movimentado por uma prensa. Este ferramental é composto de no mínimo três componentes: "matriz", "punção superior" e "punção inferior".

- A compactação de alta velocidade do inglês "High Velocity Compaction HVC" se apresenta como uma alternativa para obtenção de peças com densidade elevada. Neste processo, o estágio de compactação pode ser de 500 a 1000 vezes mais rápido do que no caso de uma compactação convencional. A densificação é alcançada pela intensa formação de ondas de choque criadas pelo martelete hidráulico, que transfere a energia para a ferramenta de compactação e esta para o pó. A massa do martelete assim como a sua velocidade no momento do impacto determina a energia de compactação e o grau de densificação.

- A compactação isostática a frio, onde o pó é colocado num recipiente de borracha que é então selado. O recipiente vai para um vaso de pressão onde o óleo lá contido é comprimido, transferindo pressão para o pó. O que define a 
capacidade da prensa isostática é o volume do vaso de pressão.

- A compactação a quente: uniaxial e isostática é a combinação de pressão e temperatura permitindo a obtenção de materiais com densidade próxima de $100 \%$.

- A conformação sem pressão é utilizada para a fabricação de peças porosas a partir de pós que apresentem boas características de difusão. Os materiais de partida são pós-esféricos ou arredondados, com tamanho e distribuição muito bem controlados. Os pós são acondicionados em moldes, normalmente de grafite ou aço inoxidável, cujo formato é o negativo da peça que se deseja produzir.

Mediante a compactação, obtêm-se, uma peça de forma e dimensões praticamente definitivas, porém sem a necessária resistência mecânica, que somente é conseguida pela operação de sinterização (Lenel, 1984). É comum a necessidade de algumas operações de acabamento final que melhoram as propriedades e conferem às peças as tolerâncias definitivas.

\subsubsection{Aquecimento ou sinterização}

A sinterização é a etapa do processo de metalurgia do pó que consiste em aquecer-se o compactado verde, a temperaturas inferiores às do ponto de fusão do metal ou liga considerado, em condições controladas de temperatura, tempo e atmosfera. A sinterização é extremamente dependente da temperatura, porque todos os mecanismos que operam durante 0 processo são termicamente ativados. Normalmente, a temperatura especificada é da ordem de 2/3 a 3/4 da temperatura de fusão da liga considerada. Para os sistemas onde há vários constituintes, a sinterização é realizada a uma temperatura superior à do metal de menor ponto de fusão (German, 1998).

$\mathrm{Na}$ Fig. 21 é possível observar que com o aumento da temperatura de sinterização é possível aumentar tamanho de grão, densidade e resistência, bem como diminuir porosidade e resistividade elétrica, ou seja, com a diminuição da porosidade, ocorre o aumento da resistência do material, observando-se que conforme o aumento de temperatura aumenta-se muito o tamanho de grão. 


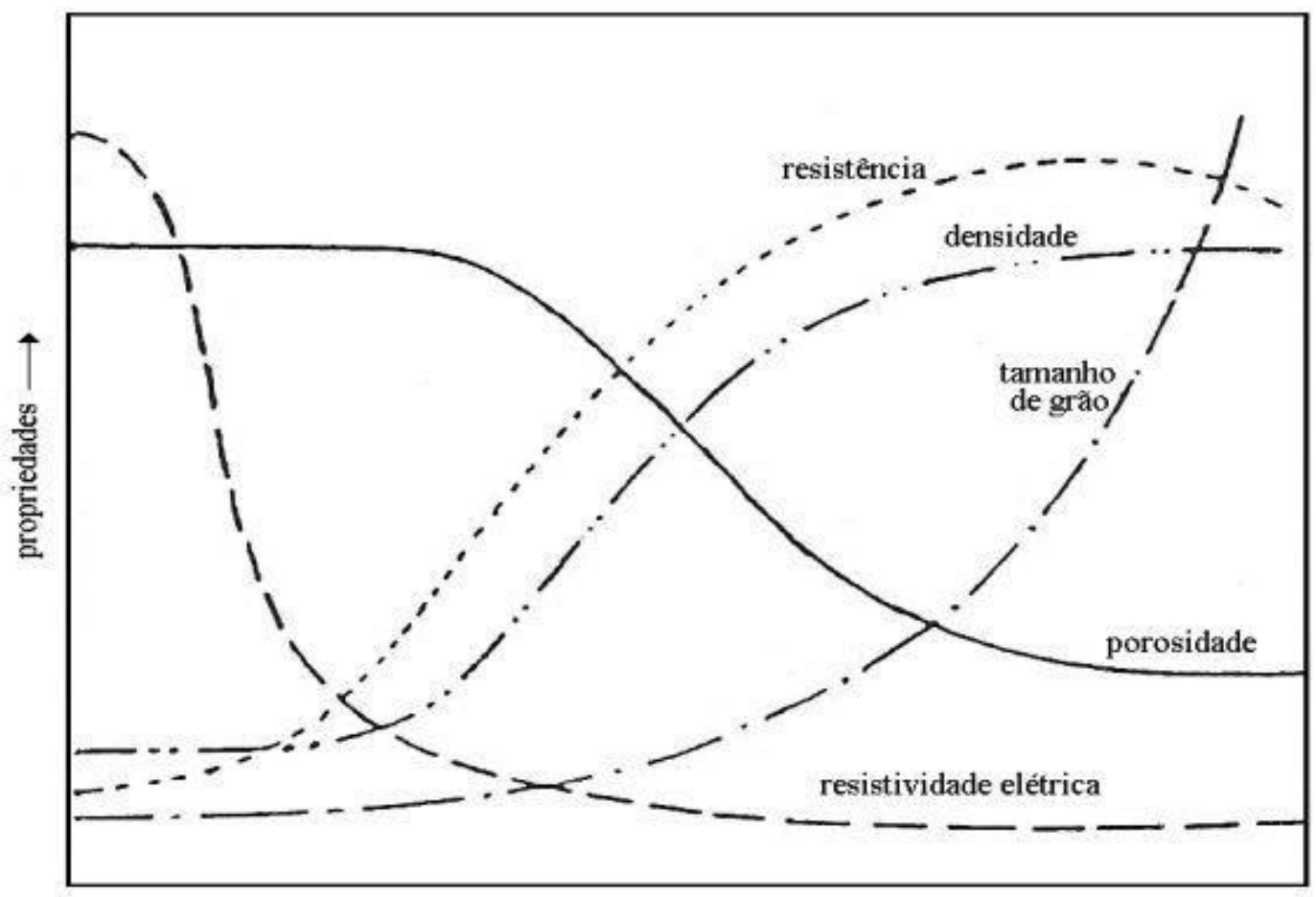

Temperatura de sinterização $\longrightarrow$

Figura 21. Efeito ilustrativo da operação de sinterização sobre várias características do material (Henry, 1973).

O emprego de uma atmosfera controlada na etapa de sinterização é fundamental, pois ela tem por objetivos:

- prevenir ou minimizar qualquer reação química entre o compactado verde, que em geral se caracteriza sempre pela presença de alguma porosidade, e o ambiente. A oxidação é o fenômeno mais importante que uma atmosfera controlada evita;

- remover impurezas presentes, principalmente películas de óxido, existentes não só na superfície como também no interior do compactado, devido sua porosidade típica;

- eventualmente, fornecer um ou mais elementos químicos para se ligarem com o metal do compactado. A atmosfera pode, por outro lado, atuar de modo a manter uma condição de equilíbrio, impedindo que não se perca algum elemento de liga presente no compactado (Thümmler et al, 1967).

\section{Natureza e propriedades de algumas atmosferas de sinterização}

Existem diferentes tipos de atmosferas para sinterização, as quais devem ser cuidadosamente selecionadas de acordo com o material a ser sinterizado, e 
evidentemente o custo envolvido. As atmosferas possíveis de serem utilizadas em processos de sinterização são: o vácuo, hidrogênio, nitrogênio, gases nobres (Ar e He), amônia dissociada, e o grupo dos gases parcialmente queimados (Thümmler et al, 1967).

Hidrogênio $\left(\mathrm{H}_{2}\right)$ - altamente redutora para a maioria dos óxidos metálicos; devido fácil inflamação, exige cuidadoso manuseio; muito leve e suscetível de escapar de aberturas no topo do forno; excelente condutor de calor; impurezas como oxigênio e vapor de água são fáceis de remover. Sua aplicação devido ao alto custo, é limitada à redução de óxido de ferro para fabricação de pó de ferro, sinterização de metal duro, imãs Alnico, níquel, aço inoxidável.

Nitrogênio $\left(\mathbf{N}_{2}\right)$ - puro por ser inerte é indicado para sinterização de ligas de alumínio onde não é necessária a característica redutora. $O \mathrm{~N}_{2}$ pode ser combinado com 3 a $5 \%$ vol. de $\mathrm{H}_{2}$, tornando a mistura não inflamável e com suficiente potencial redutor para muitas aplicações práticas na metalurgia do pó. Reage com alguns elementos e pode formar compostos de nitrogênio, alterando as propriedades do material sinterizado. Não é usado com muita frequência, como atmosfera de sinterização, mas sim para purgar os fornos em que se utilizam atmosferas inflamáveis.

Gases nobres - argônio (Ar) e hélio (He) - essas atmosferas têm sido utilizadas por serem inertes, principalmente na sinterização de aços inoxidáveis, tântalo, titânio, tório, tungstênio e suas ligas, urânio, vanádio e zircônio. Seu custo é muito elevado. A aplicação dos gases nobres está normalmente restrita a laboratórios.

Vácuo - o vácuo é a atmosfera mais adequada para muitas aplicações, entretanto, o custo dos equipamentos restringe sua utilização somente para casos especiais ou pesquisas em laboratórios.

A total ausência de qualquer atmosfera tem sido empregada na sinterização de aços inoxidáveis, tântalo, titânio, tório, tungstênio e suas ligas, urânio, vanádio e zircônio e também metal duro, alumínio, ferro, ferro-cobre, combinação de material cerâmico/metálico (cermet), molibdênio, nióbio e açoscarbono e aços-liga.

Amônia dissociada - é utilizada normalmente na sinterização de ferros e aços com baixa ou moderada quantidade de carbono, bem como para peças de bronze e latão. Possui $75 \%$ de hidrogênio; por isso é altamente redutora e 
inflamável; empregada praticamente na sinterização de todos os materiais (Chiaverini, 2001).

Os gases parcialmente queimados são obtidos a partir de hidrocarbonetos ou gases contendo os mesmos pela combustão parcial com ar seco. É comum separá-los em duas categorias em função do calor integrante da reação: endogás e exogás. Apresentam baixo custo de produção e seus constituintes principais são: $\mathrm{N}_{2}(40-90 \%), \mathrm{H}_{2}, \mathrm{CO}, \mathrm{CO}_{2}$ e $\mathrm{H}_{2} \mathrm{O}$. Devido à propriedade descarbonetante das atmosferas exotérmicas, as mesmas são mais utilizadas para sinterização de bronzes, latões e ligas de cobre enquanto que as atmosferas endotérmicas são principalmente utilizadas na sinterização dos aços (German, 1984; Thümmler, 1993).

A sinterização objetiva conferir à massa compactada verde as ligações definitivas entre as partículas de pó, fixando assim as propriedades finais e resultando em uma massa ou corpo coeso.

No início do processo de sinterização ocorre transporte de material por difusão, aumentando o contato entre as partículas e a ligação inicial entre elas. Em decorrência desta ligação há a formação de contornos de grão e crescimento de pescoços, de união inter-partículas, levando o sistema a densificação e contração volumétrica (Hirschhorn, 1969), vide exemplo na Fig. 22. Na ausência de poros interligados, o crescimento de pescoço e fechamento dos canais que interligam os poros estará praticamente ausente.

A densificação do material depende das características do pó, uma vez que o processo de sinterização decorre em camadas de pó. Aspectos como a distribuição granulométrica, forma da partícula e densidade aparente interferem diretamente com o nível de temperatura atingido localmente e com os gradientes de temperatura em cada camada e entre camadas de pó adjacentes.

A sinterização como a etapa mais complexa na rota da metalurgia do pó, é influenciada por diversos parâmetros que atuam simultaneamente no processo e a diversidade de sistemas impossibilitou até o momento, elaborar um modelo único de sinterização que seja capaz de atender os mais variados e possíveis sistemas (Silva et al, 1998). 


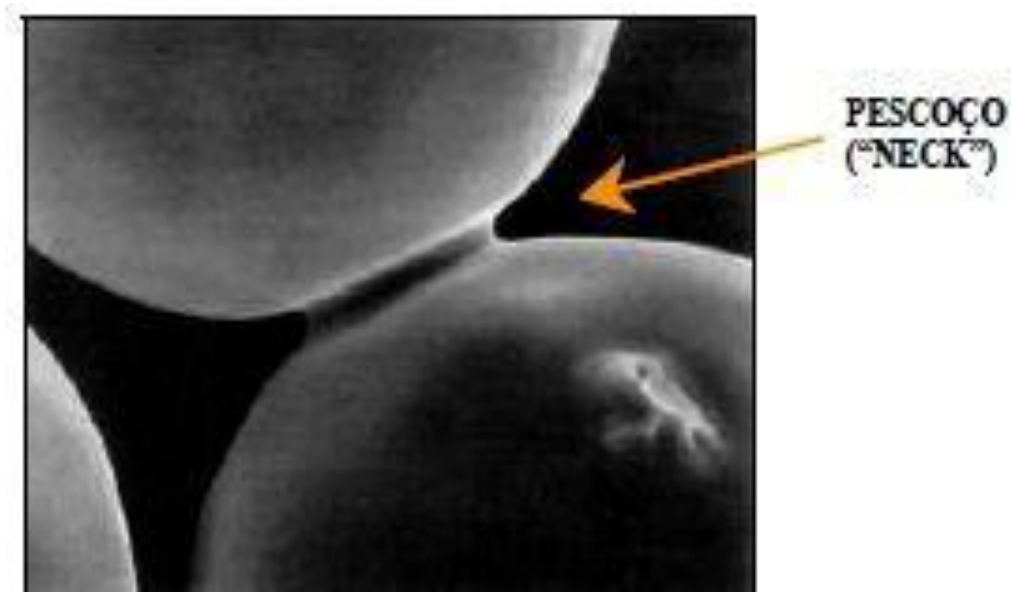

Figura 22. Formação de pescoço (neck) em consequência da ligação inicial entre as partículas (German, 1984).

A sinterização é comumente processada em fornos contínuos ou semicontínuos, caracterizado por três zonas de operação: pré-aquecimento; manutenção da temperatura (patamar) e; resfriamento. A Tab. 8 compila uma lista de temperaturas e tempos de sinterização para alguns materiais (Chiaverini, 2001).

Tabela 8. Temperaturas e tempos de sinterização para alguns materiais (Chiaverini, 2001).

\begin{tabular}{lcc}
\hline Material & Temperatura $\left({ }^{\circ} \mathbf{C}\right)$ & Tempo (min.) \\
\hline Alumínio & $595-625$ & $10-30$ \\
\hline Bronze & $760-860$ & $10-20$ \\
\hline Cobre & $\mathbf{8 4 0 - 9 0 0}$ & $\mathbf{1 2 - 4 5}$ \\
\hline Latão & $840-900$ & $10-45$ \\
\hline Ferro, ferro grafita & $1000-1150$ & $\mathbf{8 - 4 5}$ \\
\hline Níquel & $\mathbf{1 0 0 0 - 1 1 5 0}$ & $\mathbf{3 0 - 4 5}$ \\
\hline Aço inoxidável & $1090-1290$ & $30-60$ \\
\hline Imãs Alnico & $1215-1300$ & $120-150$ \\
\hline Metal duro & $1425-1480$ & $20-30$ \\
\hline
\end{tabular}

Os tempos e temperaturas de sinterização são escolhidos visando obter um corpo com porosidade, tamanho de grão, resistência mecânica, rigidez ou qualquer outra propriedade definida. Existem, dois tipos básicos de sinterização: a sinterização por fase sólida e a sinterização por fase líquida. Estes dois tipos são 
capazes de densificar total ou parcialmente a estrutura, sendo que com a sinterização por fase sólida é possível se obter uma estrutura com porosidade controlada, enquanto que o fechamento total da porosidade é facilmente obtido através da sinterização por fase líquida (Silva Jr., 1998).

A sinterização é a ligação em conjunto de partículas a temperaturas elevadas. Isso pode ocorrer a temperaturas inferiores ao ponto de fusão por eventos de transporte atômico do estado sólido, mas em muitos casos envolve a formação de uma fase líquida. Em uma escala microestrutural a ligação ocorre como pescoços coesos que crescem nos contatos entre partículas, elevando a resistência do sinterizado. As partículas sinterizam-se por movimentos atômicos que eliminam a elevada energia da superfície associada ao pó (Moon, 1979). A energia de superfície por unidade de volume depende do inverso do diâmetro da partícula. Tipicamente, a energia de superfície é avaliada pela área de superfície. Assim, as partículas menores, com áreas de superfície específicas elevadas têm mais energia e mais rápida sinterização. No entanto, nem toda a energia de superfície está disponível para a sinterização. Em um sólido cristalino, quase todos os contatos entre as partículas irão evoluir para um contorno de grão, com uma energia de contorno de grão associados. Os contornos de grão, importantes para o movimento atômico, são regiões defeituosas com alta mobilidade atômica. O mecanismo de sinterização descreve a trajetória do movimento atômico que produz o fluxo de massa. Dois fatores contribuem para a sinterização: movimentação atômica e as tensões relacionadas, a curvatura das superfícies e as interfaces. A relação entre as tensões $(\sigma)$ geradas pelas forças capilares e a tensão de superfície ( $y$ ) é dada pela equação de Laplace (Thümmler et al, 1967).

$$
\sigma=y\left(R_{1}^{-1}+R_{2}^{-1}\right)
$$

onde:

$y=$ tensão de superfície e

$R_{1}$ e $R_{2}=$ raios de curvatura das partículas em contato

São inúmeras as teorias existentes que objetivam explicar os fenômenos que ocorrem durante a sinterização. Assim, diante das considerações anteriores pode-se dizer que a teoria da sinterização se resume nos seguintes estágios:

- ligação inicial entre as partículas e formação de um pescoço;

- crescimento do pescoço; 
- fechamento dos canais que interligam os poros;

- arredondamento dos poros;

- densificação ou contração dos poros;

- crescimento eventual dos poros.

A prática da sinterização é relativamente simples, desde que se disponha de equipamento adequado (fornos, atmosferas protetoras e instrumentos de medição e controle). Contudo a sinterização depende de uma série de fatores que afetam os resultados finais, tornando-a uma operação delicada, que exige rigoroso conhecimento e controle de todas as variáveis do processo. Essas variáveis são: a natureza do pó, a natureza da mistura do pó, as características dos compactados verdes obtidos na primeira fase de consolidação, tais como porosidade, densidade, resistência a verde, entre outros.

\section{Sinterização por fase líquida}

A sinterização por fase líquida é um processo de densificação usado na produção de materiais, cujas características representam dificuldade para a sua sinterização em estados sólidos. Neste tipo de sinterização, o sistema consiste de pelo menos dois componentes, onde um deles é uma fase líquida que surge a uma dada temperatura em consequência a fusão de um dos componentes ou do resultado de uma reação entre eles, vide Fig. 23. A presença do líquido é responsável pela rapidez e elevado percentual de densificação da estrutura. Os mecanismos de densificação atuantes são dependentes da quantidade de líquido presente na estrutura e da interação deste líquido com a fase sólida. A teoria por sinterização por fase líquida divide o processo de densificação em três estágios que se desenvolvem ao mesmo tempo, com cada um dos estágios descritos em relação ao mecanismo dominante naquele estágio. Os mecanismos são: rearranjo, solução - reprecipitação e estado sólido (German, 1984).

Algumas características típicas dos materiais sinterizados fazem com que cuidados especiais sejam observados na escolha do forno para sinterização. A peça sinterizada é porosa e, portanto, tem maior área superficial em contato com a atmosfera; a temperatura durante a fase de sinterização, para garantir a perfeita união das partículas do compactado, é mais alta do que a usada na maioria dos demais tratamentos. A combinação destas variáveis aumenta a reatividade entre 
a superfície da peça e a atmosfera, exigindo maiores cuidados no controle da atmosfera utilizada, bem como na estanqueidade do forno.

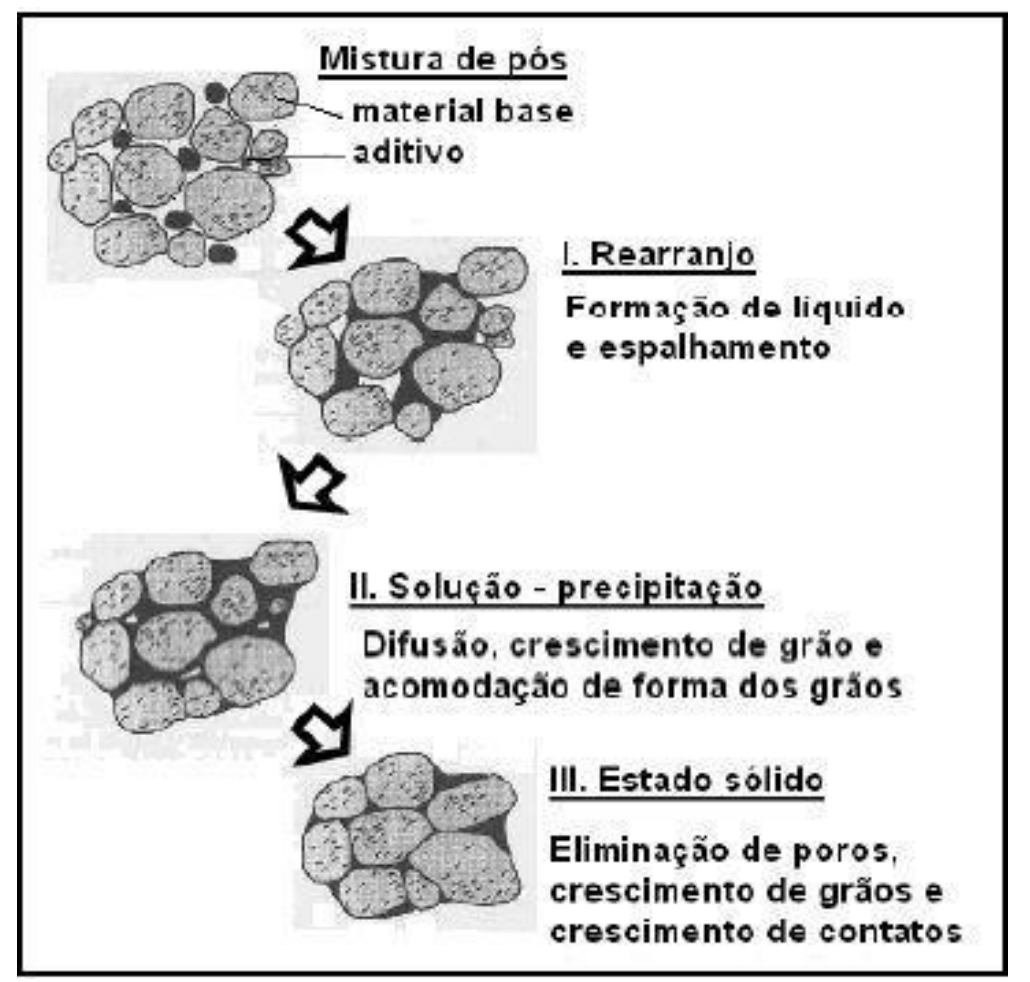

Figura 23. Estágios da sinterização por fase líquida (German, 1984).

Fornos contínuos é o recurso mais utilizado devido a grande capacidade de carga e boa produtividade. Tipicamente os fornos contínuos possuem quatro secções distintas:

- pré-aquecimento, que permite um aquecimento mais gradual da carga que é introduzida no forno, liberando o lubrificante utilizado na compactação do produto. A temperatura nesta fase de pré-aquecimento é de $500^{\circ} \mathrm{C}$ - $800^{\circ} \mathrm{C}$. O aquecimento em geral é elétrico ou a gás;

- zona de sinterização promove a ligação das partículas do compactado, aumentando a densidade da peça. Para sinterizações de ferro e aço, a temperatura de operação é de até $1150^{\circ} \mathrm{C}$;

- zona de resfriamento previne o aparecimento de tensões no material, que podem ocorrem devido a choques térmicos. Nesta fase parte do carbono perdido na zona de sinterização é novamente absorvido pelo material da peça;

- a zona de resfriamento final tem a função de resfriar as peças abaixo do seu ponto de oxidação, em atmosfera controlada, antes das mesmas entrarem em 
contato com o ar externo.

\subsubsection{Usinagem}

Embora uma das grandes vantagens da metalurgia do pó seja a de permitir a produção de peças na forma e dimensões definitivas, dentro de estreitas tolerâncias dimensionais, ainda assim, frequentemente é necessário aplicar-se operações de usinagem, com o objetivo, por exemplo, de produzir ângulos reentrantes, sulcos anulares, orifícios laterais, roscas e peculiaridades similares. O processo de usinagem produz peças pela remoção de materiais em partes ou em toda a extensão da peça por meio da utilização de ferramentas de corte, que aplica uma força concentrada sobre uma pequena área do material, a fim de conferir forma e acabamento planejados à peça.

Tecnicamente, a usinagem é a operação executada por uma máquina operatriz que removendo matéria prima e produzindo cavacos por meio de uma ferramenta de corte, confere a forma, dimensão e acabamento a uma peça, utilizando a ação cisalhante de uma ferramenta cortante (Marcondes, 1990).

As características do metal (tipo de processamento, microestrutura, propriedades mecânicas, existência de inclusões metálicas ou não, composição química e etc.) têm forte influência na usinagem. Um material obtido pela metalurgia do pó, por exemplo, o qual pela sua natureza possui porosidade interna (vide Fig. 24), pode configurar no processo de usinagem uma condição conhecida como "corte intermitente ou interrompido". Esta condição pode ser prejudicial à ferramenta de usinagem (German, 1984).

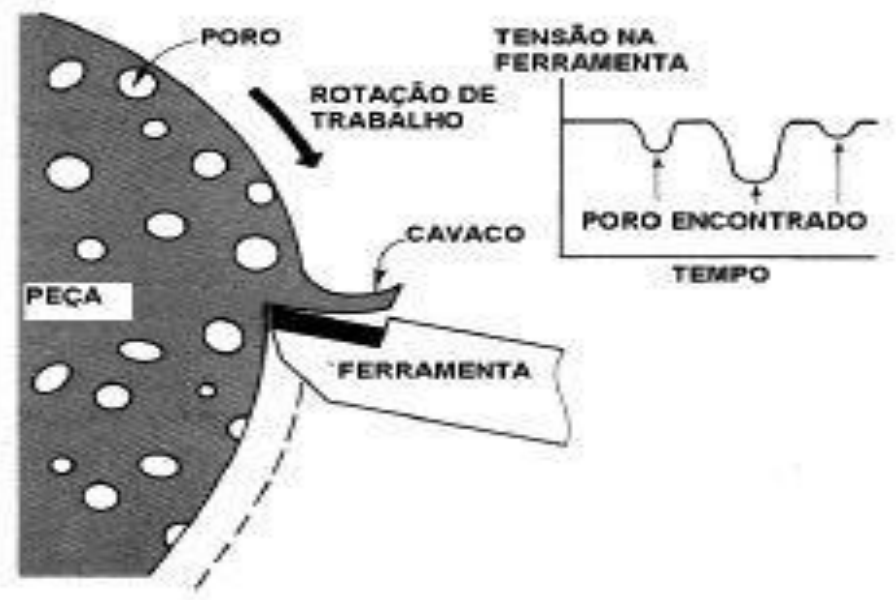

Figura 24. Torneamento cilíndrico externo de um material obtido pela metalurgia do pó (German, 1984). 
Os poros inerentes produzem um estado cíclico de tensão e deflexão na ferramenta que leva a diminuição de sua vida (German, 1984). Uma alternativa bastante utilizada na metalurgia do pó é preencher por infiltração, os poros do material com outro de menor ponto de fusão, antes de efetuar a usinagem (vide Fig. 25). O cobre tem sido bastante utilizado com esta finalidade, pois além de melhorar a densificação, ainda funciona como um ativador do processo de sinterização por fase sólida (Oliveira et al, 1999). É também adicionado com o objetivo de melhorar a condutividade térmica do alvo e sua usinabilidade, na medida em que, preenchendo os poros do compactado elimina o efeito de corte intermitente ou interrompido. A infiltração ocorre normalmente na etapa de sinterização do material.

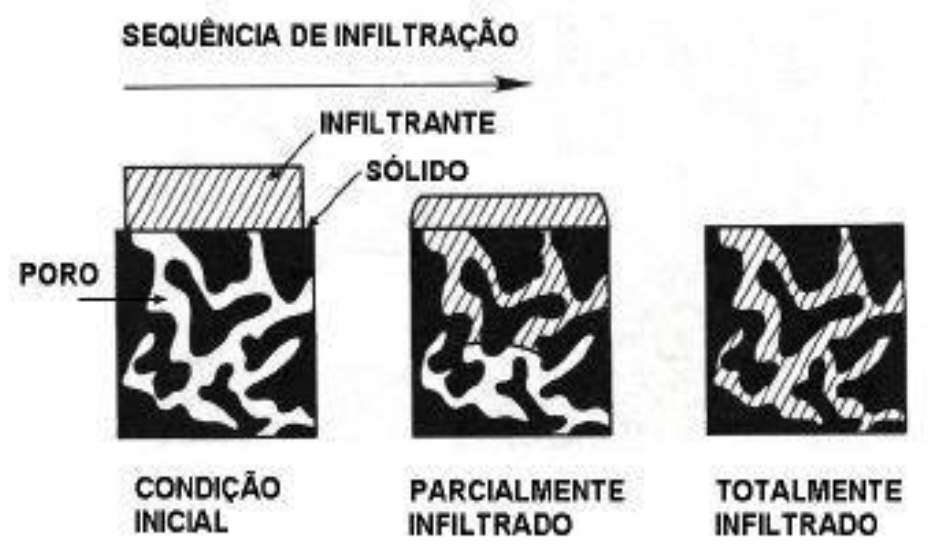

Figura 25. Esboço da sequência de infiltração de um material. Forças de capilaridade puxam o metal fundido para dentro dos poros abertos (German, 1984). 


\section{MATERIAIS E MÉTODOS}

O desenvolvimento deste trabalho de pesquisa foi dividido em várias etapas. A primeira etapa foi no sentido de caracterizar os pós de níquel e cobre utilizados. Isto sob vários aspectos como composição química e distribuição de tamanho de partículas e morfologia.

A segunda etapa deste trabalho de pesquisa foi no sentido de avaliar o desempenho do compactado em relação à densificação com o tempo. Para tanto manteve-se uma mesma pressão de compactação $195 \mathrm{MPa}$ e temperatura de sinterização $600{ }^{\circ} \mathrm{C}$, variando-se o tempo de sinterização entre $2 \mathrm{~h} \mathrm{e} 24 \mathrm{~h}$ em atmosfera com um certo grau de proteção proporcionado pela presença de cavacos de titânio.

A terceira etapa envolveu a variação da pressão de compactação tendo sido usado uma prensa hidráulica axial, aplicando diferentes pressões de compactação até $800 \mathrm{MPa}$, mantendo-se a temperatura de sinterização em 600 ${ }^{\circ} \mathrm{C}$, em atmosfera de hidrogênio por tempos de $4 \mathrm{~h}$ e $4 \mathrm{~h}+8 \mathrm{~h}$.

A quarta etapa envolveu, para alguns compactados, uma reprensagem isostática a frio a $206 \mathrm{MPa}$ e sinterização a $600 \stackrel{\circ}{\mathrm{C}}$ variando-se a atmosfera do forno e o tempo mantido em $24 \mathrm{~h}$.

Para as etapas três e quatro, os compactados foram sinterizados sob atmosferas de alto vácuo, hidrogênio e argônio, mantendo-se a temperatura de sinterização em $600{ }^{\circ} \mathrm{C}$.

$\mathrm{Na}$ quinta etapa, os compactados passaram pelo processo de sinterização por dois corpos, tendo sido usado como material infiltrante o pó de cobre, visando à eliminação de porosidade interconectada. Isto com 0 objetivo de permitir 0 selamento do conteúdo físsil no interior do compactado. A temperatura de sinterização foi de $1150 \stackrel{\circ}{\mathrm{C}}$ em forno contínuo industrial sob atmosfera de $70 \% \mathrm{H}_{2}$ e $30 \%$ de $\mathrm{N}_{2}$ por um período de $50 \mathrm{~min}$.

$\mathrm{Na}$ sexta etapa, alguns compactados de níquel foram montados com um 
núcleo em aço AISI 304, para simular a presença, sob alguma extensão, do núcleo de urânio.

Após sinterização, os compactados foram caracterizados fisicamente sendo avaliada a massa específica pelo método geométrico e pelo princípio de Arquimedes. Os compactados sinterizados foram ensaiados mecanicamente em compressão numa máquina de ensaios mecânicos universal. Finalmente, os compactados foram caracterizados microestruturalmente por microscopia óptica e eletrônica de varredura. Estas etapas estão melhor detalhadas a seguir.

\subsection{Caracterização dos pós - primeira etapa}

Impurezas não metálicas geralmente causam efeitos adversos na compressibilidade e na vida útil das ferramentas de compactação. Já as propriedades geométricas, que envolvem tamanho de distribuição de partículas, forma e porosidade da partícula, determinam a superfície específica do pó que é a força motriz do processo de sinterização. A qualidade do pó metálico é função do processo de fabricação (Handbook, 1997).

A determinação das características dos pós-metálicos, é necessária para compreender o comportamento do pó em serviço, determinar a tolerância nas especificações relacionadas com as propriedades e, fator mais importante, assegurar a reprodução do comportamento do pó durante o seu processamento. Para esse controle, se faz necessário o conhecimento quanto a: amostragem, pureza e composição química, microestrutura da partícula, tamanho e forma de partícula, porosidade, densidade aparente, densidade batida, velocidade de escoamento, superfície específica, compressibilidade, resistência em verde, mudanças dimensionais da peça compactada, entre outros (Chiaverini, 2001).

O trabalho foi desenvolvido, usando-se como base o pó de níquel de pureza comercial, na granulometria de \#325 e pó de cobre EF-98S utilizado como material infiltrante, conforme mostrado na Tab. 9. O conhecimento do teor dos elementos químicos presentes na amostra de níquel é importante para avaliação de sua qualidade, principalmente com relação a contaminantes (Lachance, 1995). O pó de níquel usado foi analisado quimicamente por fluorescência de raios $\mathrm{X}$ por dispersão de comprimento de onda, análise feita no Centro de Química e Meio Ambiente - CQMA (IPEN). O resultado é mostrado na Tab. 10. Outros resultados da caracterização do pó de níquel serão apresentados em itens subsequentes. 
Segundo certificação apresentada pelo fornecedor Combustol Metalpó, o pó de cobre é de origem importada com denominação comercial EF-98S (lasi, 2014). O pó veio certificado quanto à composição química, distribuição granulométrica, densidade aparente e escoamento, como transcrito nas Tabs. 11 a 13. A distribuição do tamanho médio das partículas do pó de níquel foi feita com o uso de granulômetro por difração de laser.

Com vista a ter maior conhecimento sobre o pó de níquel adquirido para realização deste trabalho, o mesmo foi analisado para conhecimento de sua morfologia através da microscopia eletrônica de varredura (MEV).

\subsection{Obtenção dos compactados de níquel com tempo de sinterização de 2 a}

\section{$24 \mathrm{~h}$ - segunda etapa}

A segunda etapa deste trabalho de pesquisa foi no sentido de avaliar o desempenho do compactado em relação à densificação. Para tanto manteve-se uma mesma pressão de compactação $195 \mathrm{MPa}$ e temperatura de sinterização $600 \stackrel{\circ}{\circ}$, e variou-se o tempo de sinterização em 2 a 24 h, como será melhor detalhado a seguir.

A partir do pó de níquel, procedeu-se a confecção dos compactados, utilizando-se a rota da metalurgia do pó, contemplando as etapas de compactação a frio e sinterização. Para cada amostra foi pesada $12 \mathrm{~g}$ de níquel utilizando balança analítica, com precisão de $0,001 \mathrm{~g}$, para averiguação da massa de cada amostra a verde, medida a altura e diâmetro da mesma, utilizando-se um paquímetro, veja Fig. 26

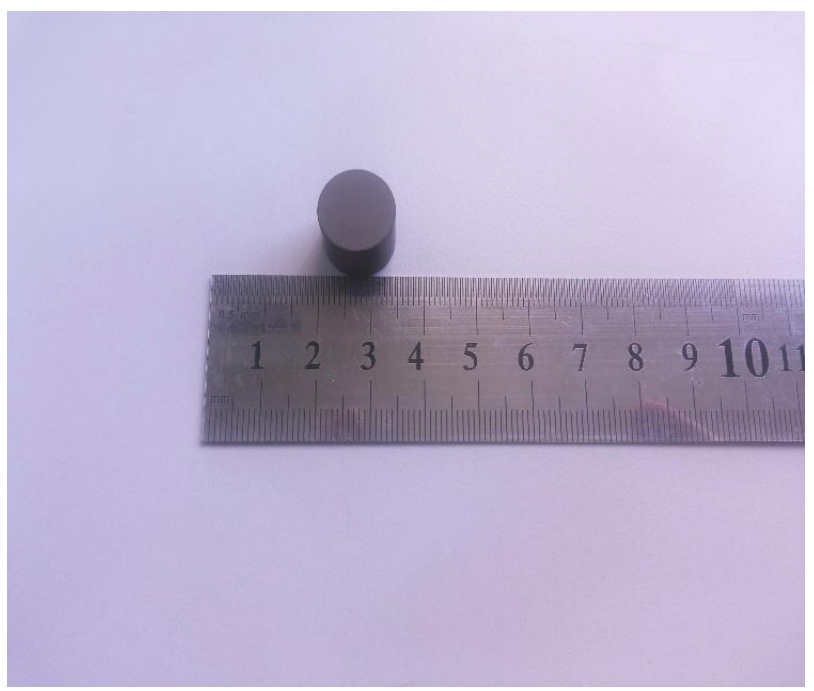

Figura 26. Imagem do compactado de níquel utilizado. 
As amostras foram compactadas em prensa hidráulica com capacidade máxima de 10 toneladas, aplicação uniaxial de carga, acionamento do travessão por dois parafusos sem-fim e operada manualmente, conforme mostrado na Fig. 27.

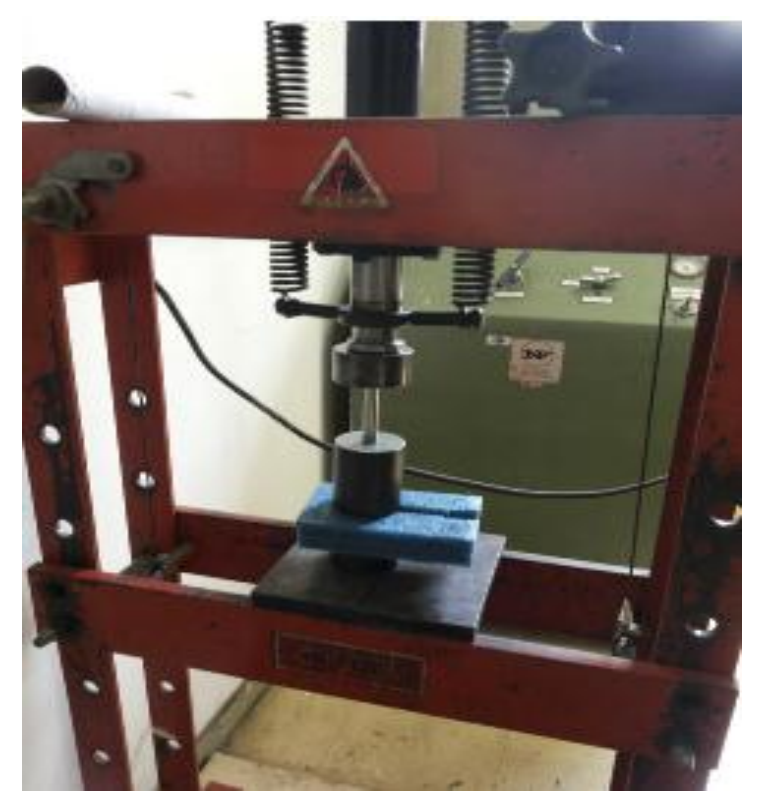

Figura 27. Prensa hidráulica com capacidade máxima de 10 toneladas.

O ferramental utilizando é composto de matriz de aço na forma cilíndrica com diâmetro interno de $14 \mathrm{~mm}$, externo de $70 \mathrm{~mm}$ e altura de $96 \mathrm{~mm}$, punção superior e punção inferior. Foi aplicado estearato de zinco como lubrificante na parede da matriz e punções para diminuir 0 atrito, evitar 0 desgaste do ferramental e facilitar a ejeção dos compactados. O estearato de zinco utilizado como lubrificante da matriz de aço, é um produto encontrado comercialmente e não foi caracterizado fisicamente nem morfologicamente, uma vez que o mesmo só foi utilizado como lubrificante durante o processamento dos materiais, sendo que na etapa de sinterização o mesmo é eliminado na temperatura de $120 \stackrel{\circ}{\circ}$.

As amostras foram compactadas com uma carga de 3 toneladas, equivalente a uma pressão de compactação de $195 \mathrm{MPa}$. A Fig. 28 mostra os compactados antes da sinterização em uma caixa de concreto celular (material inorgânico, composto de cimento, cal e areia com ponto de fusão em torno de $1200 \stackrel{\circ}{\circ})$. 


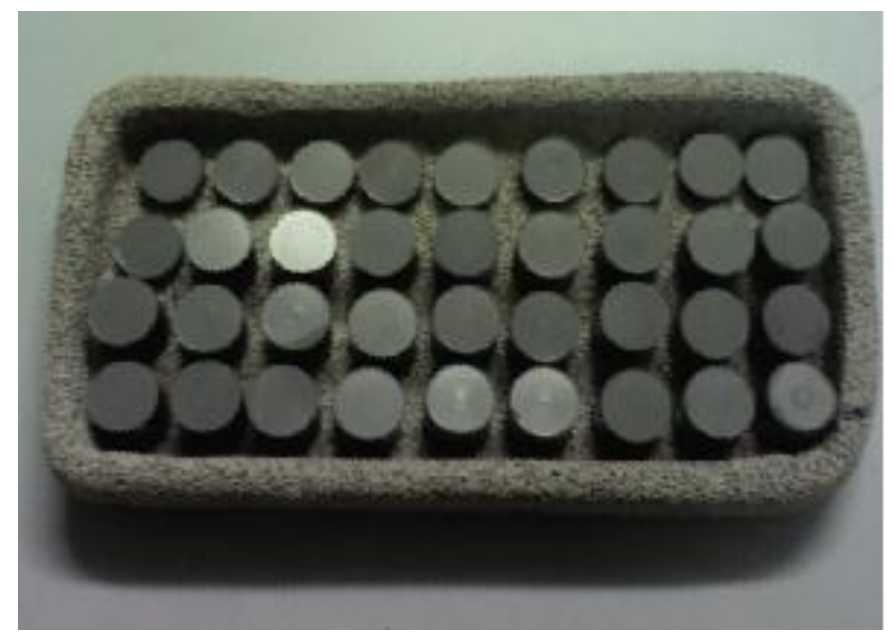

Figura 28. Para a primeira etapa da pesquisa foram compactadas amostras de níquel com pressão de compactação de $195 \mathrm{MPa}$.

O passo seguinte consistiu na sinterização de um total de 26 amostras, em um forno pré-aquecido previamente por três horas, tipo mufla, contendo cavacos de titânio no seu interior (vide Fig. 29). Após o preaquecimento, o forno foi carregado com os compactados e mantido com temperatura constante de $600{ }^{\circ} \mathrm{C}$ por 24 horas. A temperatura foi monitorada pelo termopar de controle do forno.

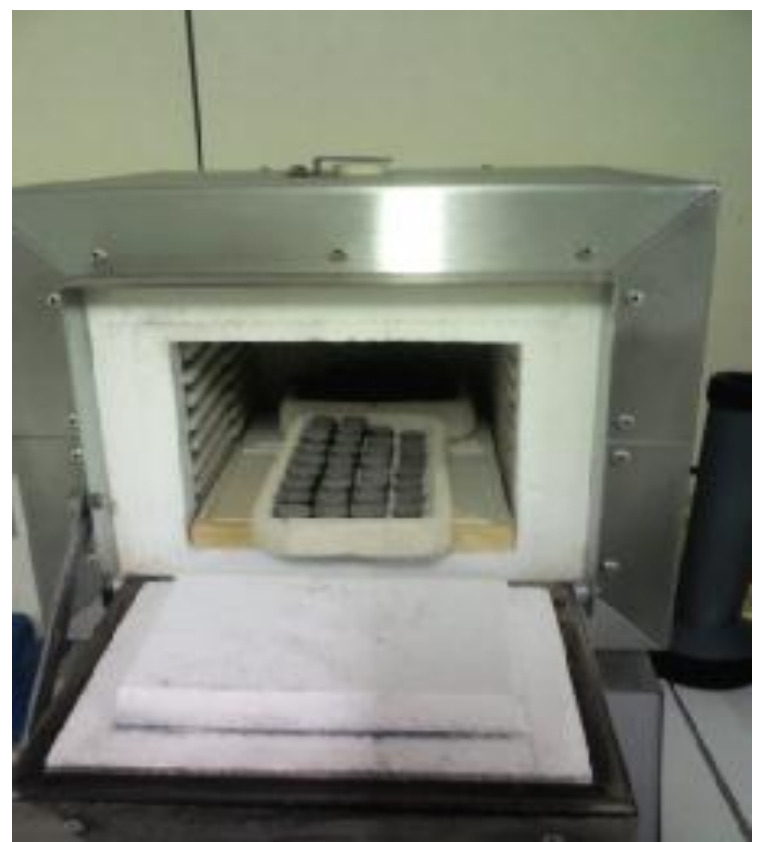

Figura 29. Forno tipo mufla utilizado na sinterização, com cavacos de titânio, dos compactados de níquel, a $600{ }^{\circ} \mathrm{C}$ por $24 \mathrm{~h}$. 
As amostras foram separadas em grupos. Os sete primeiros grupos com três amostras cada, foram retirados do forno com um intervalo de $1 \mathrm{~h}$. A retirada do primeiro grupo aconteceu após $2 \mathrm{~h}$ de encharque. $\mathrm{O}$ oitavo grupo também com três amostras, permaneceu no forno por 12 horas e o último grupo com duas amostras permaneceu no forno por 24 horas. A Fig. 30 mostra o ciclo térmico de aquecimento do forno em termos de rampa e patamares.

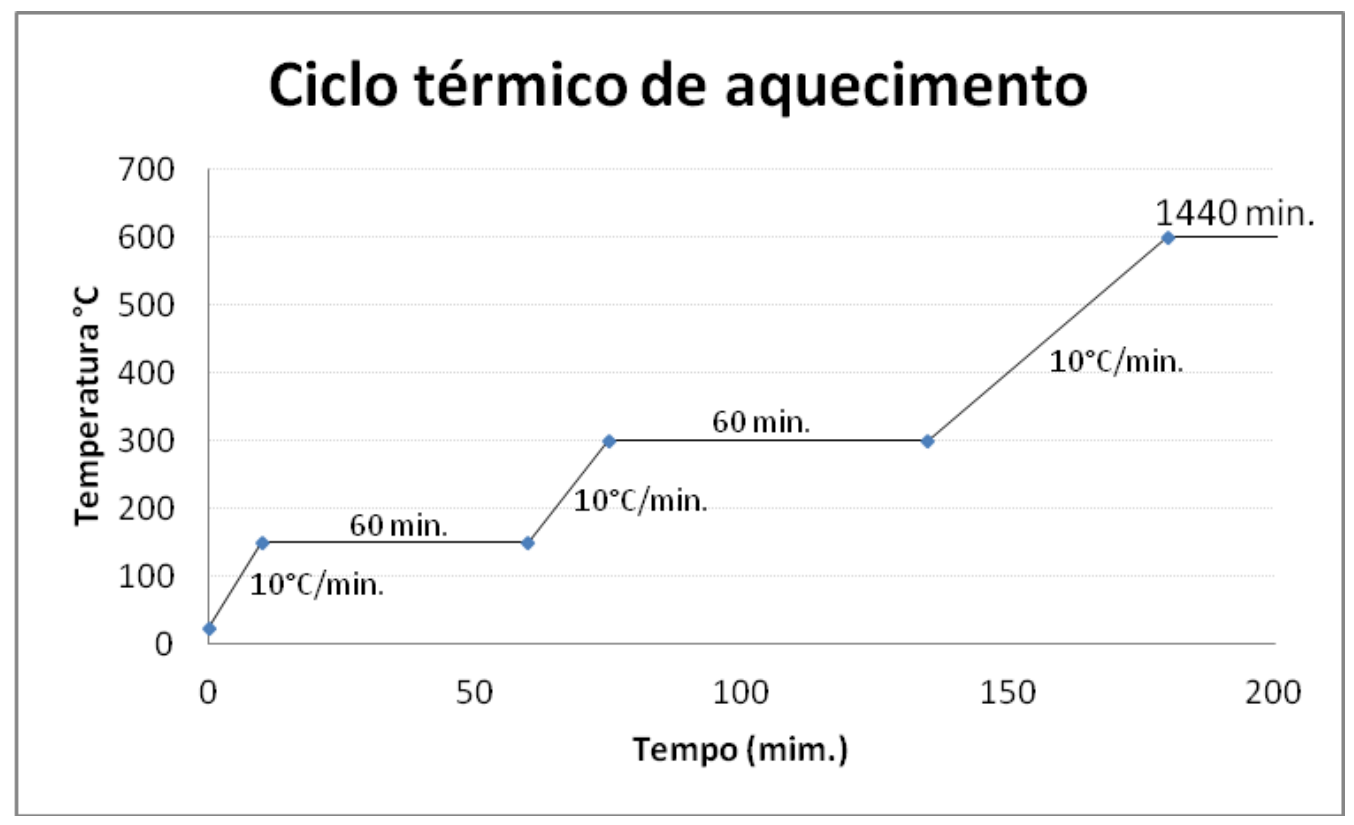

Figura 30. Ciclo térmico de sinterização adotado para os compactados obtidos e sinterizados, juntamente com os cavacos de titânio, na temperatura de $600{ }^{\circ} \mathrm{C}$ por um período de até $24 \mathrm{~h}$.

Como este trabalho se destina a obtenção de alvos para irradiação contendo urânio, o patamar de temperatura de sinterização empregado para a sinterização do níquel foi limitado a $600{ }^{\circ} \mathrm{C}$ devido ao fato de o urânio em presença de níquel a $740{ }^{\circ} \mathrm{C}$ formarem um eutético, de acordo com o diagrama de fases $\mathrm{Ni}-\mathrm{U}$ representado na Fig. 9. A variação de temperatura e a margem de segurança com relação ao forno também foram levadas em consideração, fazendo com que o patamar máximo para a sinterização não fosse ultrapassado.

\subsubsection{Caracterização do compactado a verde e sinterizado}

Os compactados no estado a verde e após sinterização, tiveram a densidade avaliada usando-se dois métodos, o geométrico e por imersão. 
Densidade aparente

A densidade aparente de um material é definida como a sua massa dividida pelo volume ocupado por esta massa. Esta propriedade pode ser determinada por diferentes técnicas. As de interesse neste trabalho foram:

Método geométrico

Esse método consiste na determinação da massa e das dimensões das amostras donde deriva-se a densidade.

Método de imersão

Este método utiliza o princípio de Arquimedes. Neste caso, as amostras são imersas em um líquido, preferencialmente a água destilada. Usando a Eq. (3) é possível obter a densidade aparente das amostras:

$$
D=\frac{A}{A-C}
$$

Onde: A - massa seca e C - massa imersa.

\subsubsection{Microscopia eletrônica após compactação}

Para a caracterização microestrutural, as amostras foram embutidas com resina acrílica e em seguida submetidas a uma sequência de polimentos, obedecendo a seguinte ordem: lixas: $320 \rightarrow 600 \rightarrow 800 \rightarrow 4000$; panos: pasta de diamante $6 \mu \mathrm{m} \rightarrow 3 \mu \mathrm{m} \rightarrow$ sílica coloidal 0,02 $\mu \mathrm{m}$. Foram utilizados os equipamentos do Laboratório de Metalurgia do CCN / IPEN para o tratamento das amostras conforme mostrado Fig. 31. 


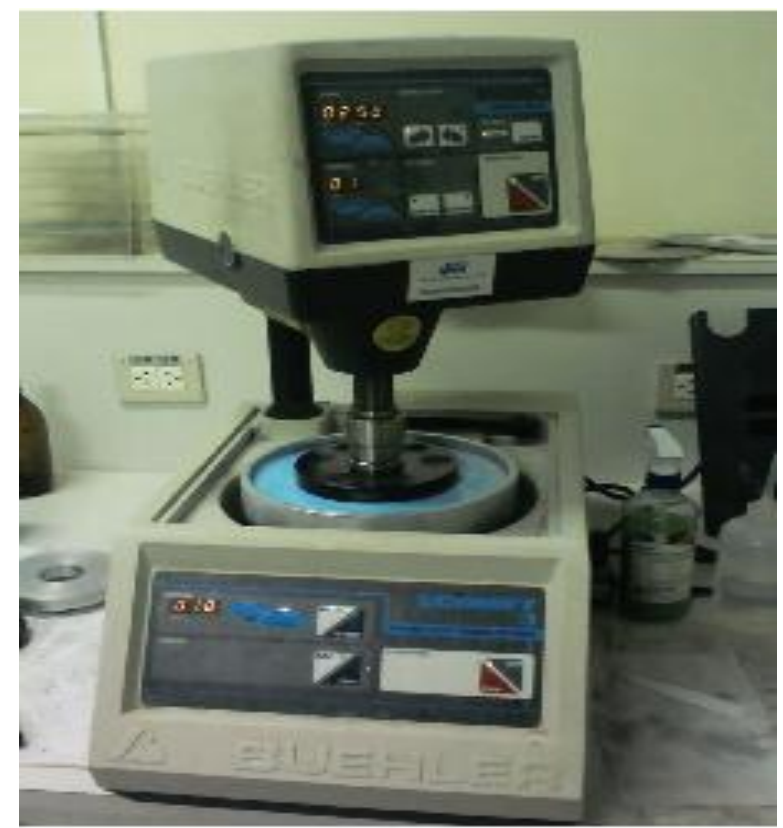

Figura 31. Politriz utilizada para o polimento final de amostras metalográficas em sílica coloidal $0,02 \mu \mathrm{m}$.

As amostras devidamente polidas foram observadas no microscópio eletrônico de varredura (MEV), sendo que uma amostra foi atacada quimicamente com solução de água régia por $1 \mathrm{~s}$.

\subsubsection{Ensaio de compressão}

Após a sinterização as amostras foram pesadas e medidas, sendo realizado o ensaio de compressão em 10 amostras selecionadas com tempo de sinterização de $2 \mathrm{~h}$ a $24 \mathrm{~h}$. Com os resultados obtidos pode-se observar a resistência mecânica em compressão do material. As amostras foram ensaiadas em uma máquina de ensaios mecânicos universal com dispositivo contendo acoplamento esférico apropriado ao ensaio de compressão, para manter a axialidade na aplicação da carga. A velocidade de movimento do travessão foi de $0,5 \mathrm{~mm} / \mathrm{min}$.

\subsubsection{Porosimetria por intrusão de mercúrio}

A porosimetria por intrusão de mercúrio é uma técnica importante para a descrição quantitativa da estrutura porosa de um sólido. Essa técnica se desenvolveu a partir da observação do comportamento de um líquido sobre um sólido poroso, o qual não é molhado pelo líquido em questão a pressão atmosférica. A equação que descrevia esse comportamento foi desenvolvida por 
Washburn em 1921 (Abrams, 1996), e tem o nome de seu autor, vide Eq. 4:

$$
d=\frac{-4 \cdot \sigma \cdot \cos \varphi}{p}
$$

Onde:

d = diâmetro do poro;

$\sigma=$ tensão superficial do líquido;

$\varphi=$ ângulo de contato entre o líquido e o sólido e;

$\mathrm{p}=$ pressão.

Essa equação é capaz de descrever o comportamento do mercúrio na superfície de um sólido e pode também ser expressa em função do raio $r$ do poro, bastando dividi-la pelo fator dois. Não sendo capaz de molhar a maioria dos sólidos conhecidos, o mercúrio só penetra nos poros dos materiais com aplicação de pressão, que será tão mais alta quanto menor for o tamanho do poro. A tensão superficial do mercúrio é alta, cerca de 490 dinas $/ \mathrm{cm}^{3}$. Esse valor alto mostra a tendência do líquido em se contrair para uma forma de área específica mínima, como resultado de forças intermoleculares em sua superfície. Por essa razão o mercúrio apresenta ângulos de contato muito altos com a maioria dos sólidos (em torno de $\left.130^{\circ}\right)$. Todas essas características fazem com que o mercúrio seja o único líquido utilizado na porosimetria por intrusão. A desvantagem da aplicação da Eq. (4) está no fato de os poros não serem normalmente circulares, levando assim a resultados somente comparativos (Webb, 1997; Abrams, 1996).

A distribuição de tamanhos de poro pode ser obtida pela porosimetria por intrusão de mercúrio por meio da medida do volume de mercúrio penetrado a uma dada pressão. O volume de mercúrio é determinado pela diferença no nível de mercúrio em contato com o fluido que exerce a pressão (Allen, 1990). O ensaio de porosimetria de mercúrio foi realizado em uma amostra compactada a $195 \mathrm{MPa}$ e sinterizada a $600 \stackrel{\circ}{\mathrm{C}}$ por 12 horas.

\subsection{Obtenção dos compactados de níquel - terceira etapa}

Nesta terceira etapa, o ciclo térmico que possuía um patamar variando de 2

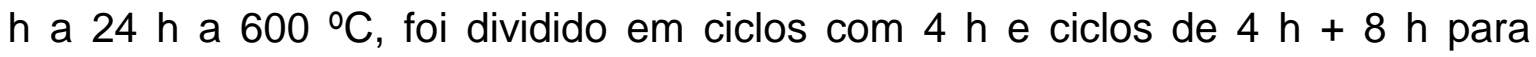
observar a densificação em função da pressão de compactação e do tempo de 
sinterização, vide ciclos térmicos nas Fig. 32 e 33. Foram sinterizadas sob atmosfera de hidrogênio $(20 \mathrm{cmHg}), 10$ amostras, compactadas em prensa axial, aplicando diferentes pressões de compactação $75 \mathrm{MPa}, 150 \mathrm{MPa}, 225 \mathrm{MPa}, 300$ $\mathrm{MPa}, 375 \mathrm{MPa}, 450 \mathrm{MPa}, 525 \mathrm{MPa}, 600 \mathrm{MPa}, 675 \mathrm{MPa}$, até $800 \mathrm{MPa}$, utilizandose $2 \mathrm{~g}$ de níquel em matriz de aço com diâmetro interno de $9 \mathrm{~mm}$.

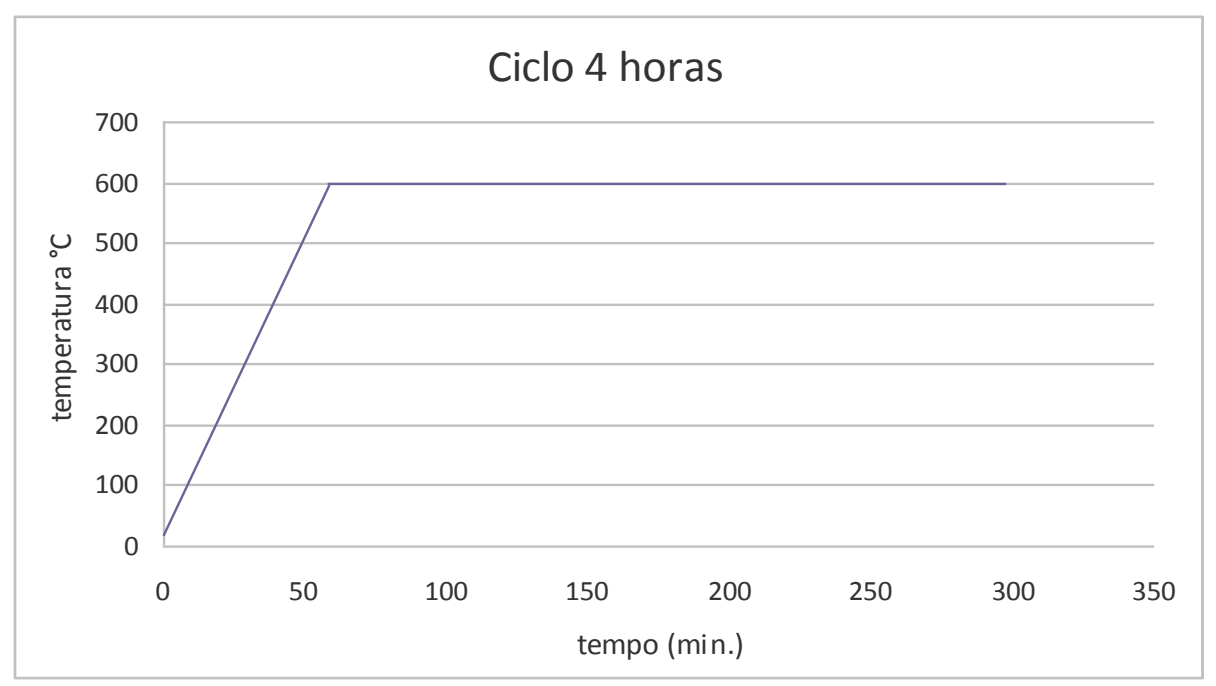

Figura 32. Ciclo térmico de sinterização com rampa de aquecimento adotado para os compactados obtidos e sinterizados na temperatura de $600 \stackrel{\circ}{\circ}$ por um período de $4 \mathrm{~h}$ em atmosfera de hidrogênio.

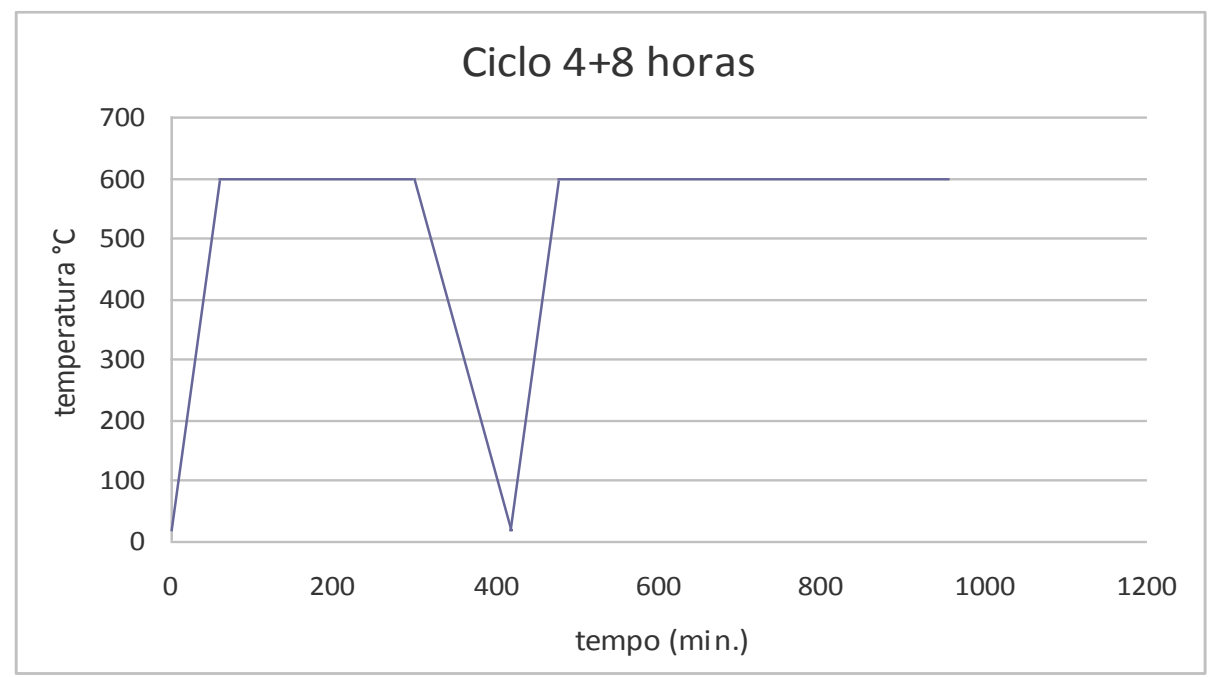

Figura 33. Ciclo térmico de sinterização com rampa de aquecimento adotado para os compactados obtidos e sinterizados na temperatura de $600 \stackrel{\circ}{\circ}$ por um período de $4 \mathrm{~h}+8 \mathrm{~h}$ em atmosfera de hidrogênio. 


\subsection{Obtenção dos compactados de níquel - quarta etapa}

A quarta etapa envolveu, para alguns compactados, uma reprensagem isostática a frio a $206 \mathrm{MPa}$ e sinterização a $600{ }^{\circ} \mathrm{C}$ variando-se a atmosfera do forno e o tempo em $12 \mathrm{~h}$. As atmosferas de fornos serão melhor explicadas separadamente, para melhor clareza, a seguir.

A sinterização em atmosfera controlada foi feita de acordo com os seguintes passos. Foram usados 3 fornos tubulares, um para cada tipo de atmosfera a saber: atmosfera de argônio, atmosfera de hidrogênio e atmosfera em alto vácuo, vide Fig. 34. Foram colocadas duas amostras em cada forno tubular com atmosferas controladas.

As amostras foram sinterizadas no forno tubular com atmosfera de argônio, (pressão de argônio: 1220 bars), por um período de 12 horas a temperatura de $600{ }^{\circ} \mathrm{C}$. Duas amostras foram sinterizadas no forno tubular com atmosfera de hidrogênio (pressão de $\mathrm{H}_{2}$ : 1250 bars) por um período de 12 horas a temperatura de $600{ }^{\circ} \mathrm{C}$.

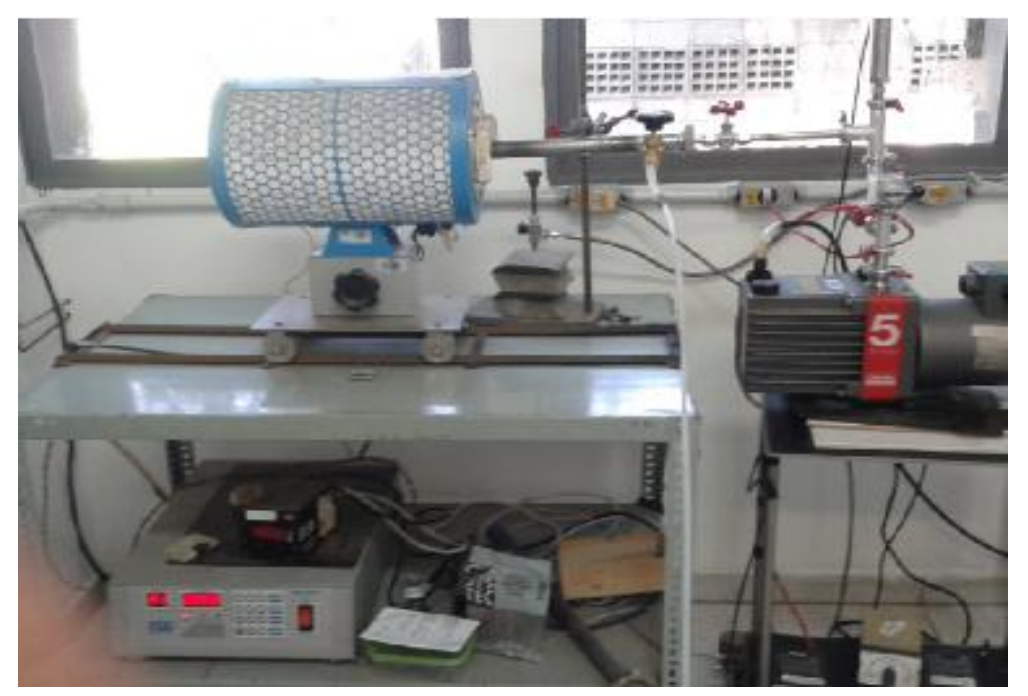

Figura 34. Forno tubular utilizado na sinterização dos compactados de níquel, utilizando como atmosfera de sinterização o argônio.

Três amostras foram sinterizadas em forno tubular com atmosfera em alto vácuo, melhor que $10^{-5}$ Torr, cujo forno é mostrado na Fig. 35. A sinterização foi por um período de 12 horas a temperatura de $600{ }^{\circ} \mathrm{C}$. Uma das amostras foi preparada metalograficamente e atacada com $\mathrm{HNO}_{3}$. 


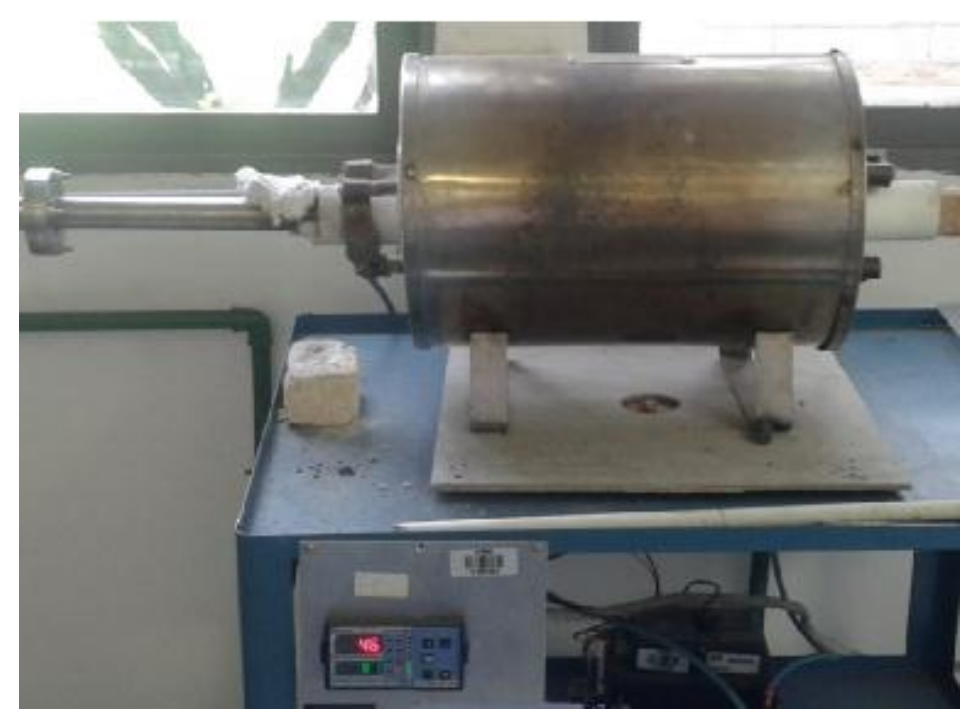

Figura 35. Forno tubular utilizado na sinterização dos compactados de níquel, utilizando como atmosfera de sinterização o vácuo.

Outras 2 amostras foram sinterizadas em forno com atmosfera controlada em alto vácuo por 24 horas a temperatura de $600{ }^{\circ} \mathrm{C}$.

\subsection{Obtenção dos compactados de níquel - quinta etapa}

$\mathrm{Na}$ quinta etapa, outros compactados passaram pelo processo de sinterização por dois corpos, tendo sido usado como material infiltrante o pó de cobre, visando à eliminação de porosidade interconectada, isto poderá permitir o selamento do conteúdo físsil no interior do compactado. A temperatura de sinterização foi de $1150{ }^{\circ} \mathrm{C}$ em forno contínuo industrial, sob atmosfera de $70 \% \mathrm{H}_{2}$ e $30 \%$ de $\mathrm{N}_{2}$, conforme mostrado na Fig. 36.

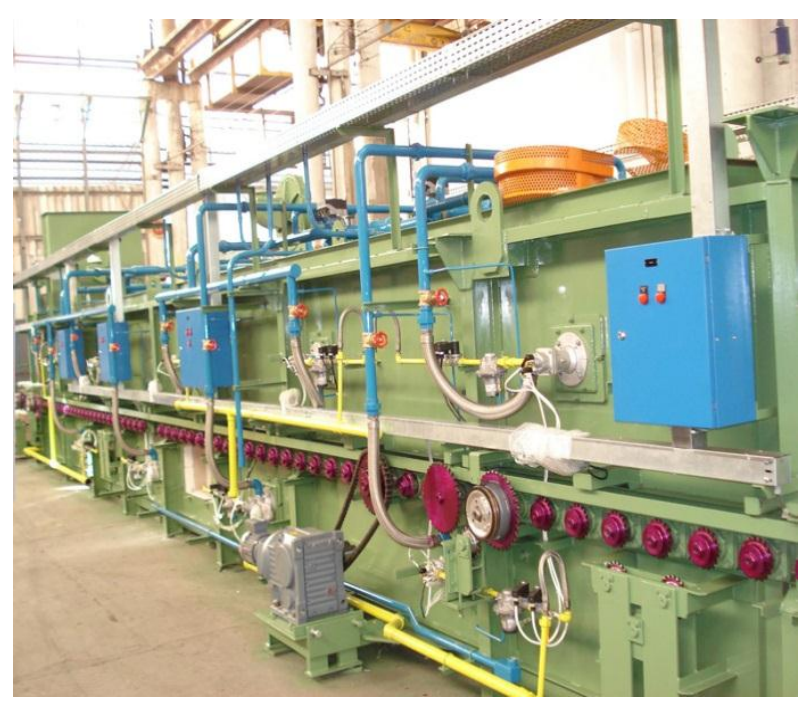

Figura 36. Forno contínuo industrial com emprego de atmosfera de $70 \%$ de $\mathrm{H}_{2} \mathrm{e}$ $30 \%$ de $\mathrm{N}_{2}$ e temperatura de $1150{ }^{\circ} \mathrm{C}$ da empresa Combustól Metalpó. 


\subsection{Obtenção dos compactados de níquel - sexta etapa}

$\mathrm{Na}$ sexta etapa deste estudo procedeu-se a partir do pó de níquel a confecção dos compactados com o núcleo em aço AISI 304, simulando o núcleo de urânio como mostrado na imagem da impressão artística mostrado na Fig. 37, utilizando a mesma pressão de compactação $195 \mathrm{MPa}$, que foi empregada na primeira etapa deste trabalho.

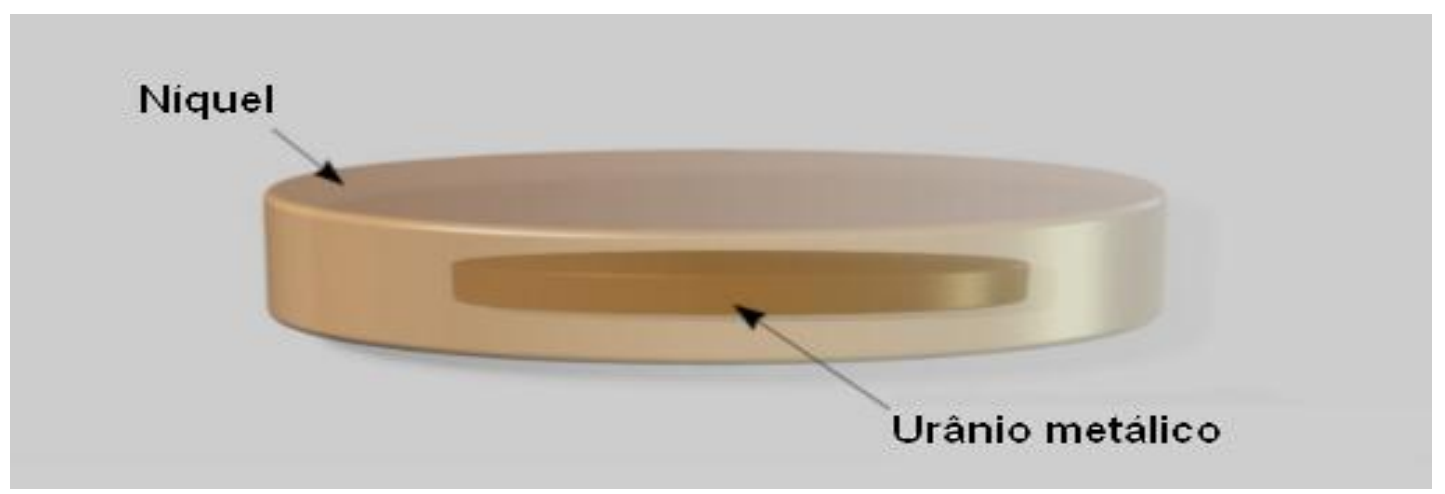

Figura 37. Impressão artística de uma pastilha de urânio metálico em pó (interno) e níquel em pó (externo).

Quatro amostras foram compactadas com o núcleo em aço inoxidável para simular o núcleo de urânio. Foi feito um cálculo de volumes e massas para o preenchimento de um invólucro do núcleo de aço inoxidável conforme Fig. 38 (a) e 38 (b).

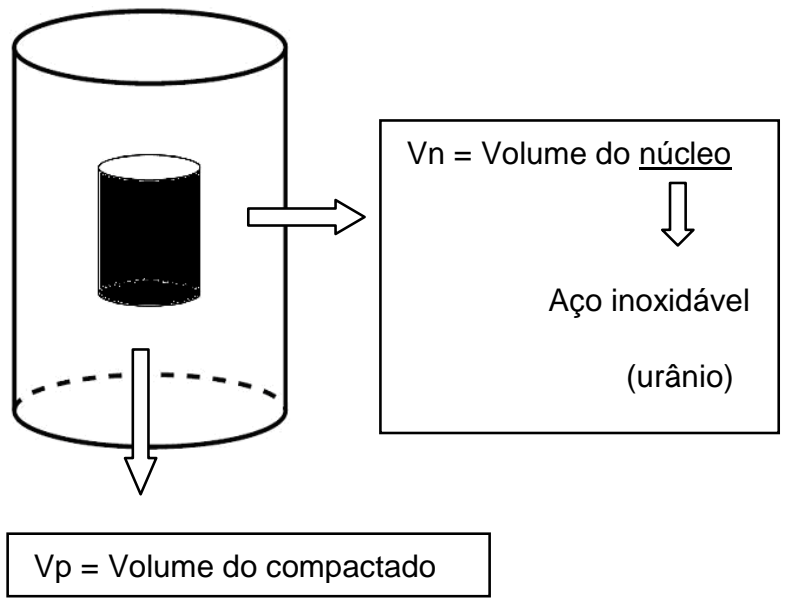

(a)

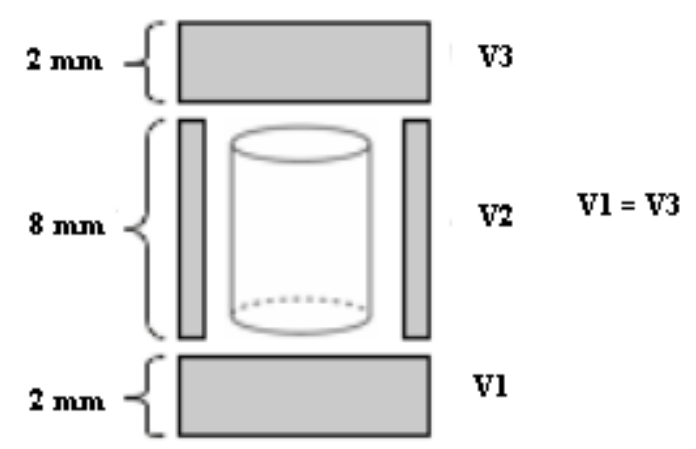

(b)

Figura 38. (a) Perspectiva do desenho do compactado, com o núcleo de aço inox simulando o núcleo de urânio no centro do compactado. (b) Cálculo da massa de níquel utilizada para construir este compactado. 
Onde:

$V c=$ Volume de pó de níquel utilizado para preencher a matriz

$V_{c}=V p-V n$

$\mathrm{Vc}=\mathrm{X}$

V2 $=(\underline{1,4-0,94})^{2} \times \pi \times 0,8 \Longrightarrow \Pi(1,4)^{2} \times 0,2$

4

4

Com os resultados obtidos pelos cálculos, pode-se dividir a massa de níquel utilizada na confecção do compactado da seguinte forma:

Primeiramente foi colocada na matriz de $14 \mathrm{~mm}$ a quantidade de níquel referente ao volume $\mathrm{V} 1$ e em seguida aplicada a pressão de compactação de 195 $\mathrm{MPa}$, sobre a amostra compactada foi centralizado o núcleo de aço AISI 304. A massa de níquel referente a lateral do compactado (V2), foi acrescentada na matriz de forma a preencher toda sua extensão e em seguida feita uma segunda compactação utilizando a mesma pressão anterior. Finalmente, foi colocada na matriz sobre o compactado pré-acabado, a quantidade de níquel referente ao volume V3 e aplicada mais uma vez a pressão de compactação anterior. Estas amostras a verde, após esse procedimento, foram observadas por meio óptico e não apresentaram trincas ou deformação. A Fig. 39 mostra o compactado de níquel já com o núcleo de aço AISI 304.

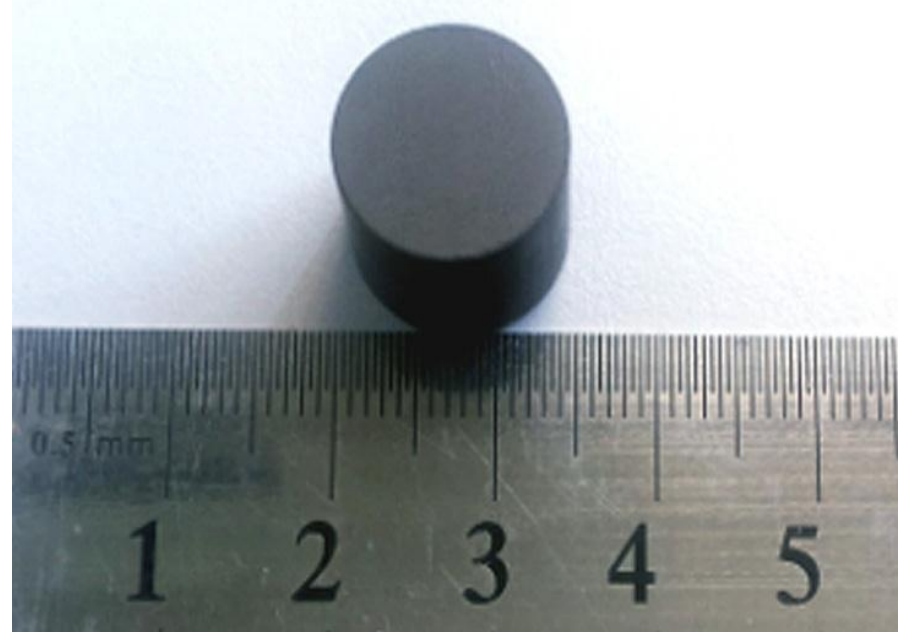

Figura 39. Compactado de níquel já com núcleo em aço AISI 304.

As amostras após a compactação foram seladas em vácuo mecânico em 
uma seladora e colocadas na prensa isostática, mostrada na Fig. 40. A pressão de compactação foi de 206 MPa (30000 psi), sendo após, sinterizadas em forno contínuo industrial a temperatura de $1150{ }^{\circ} \mathrm{C}$ com atmosfera de $70 \%$ de hidrogênio e $30 \%$ nitrogênio por $50 \mathrm{~min}$.

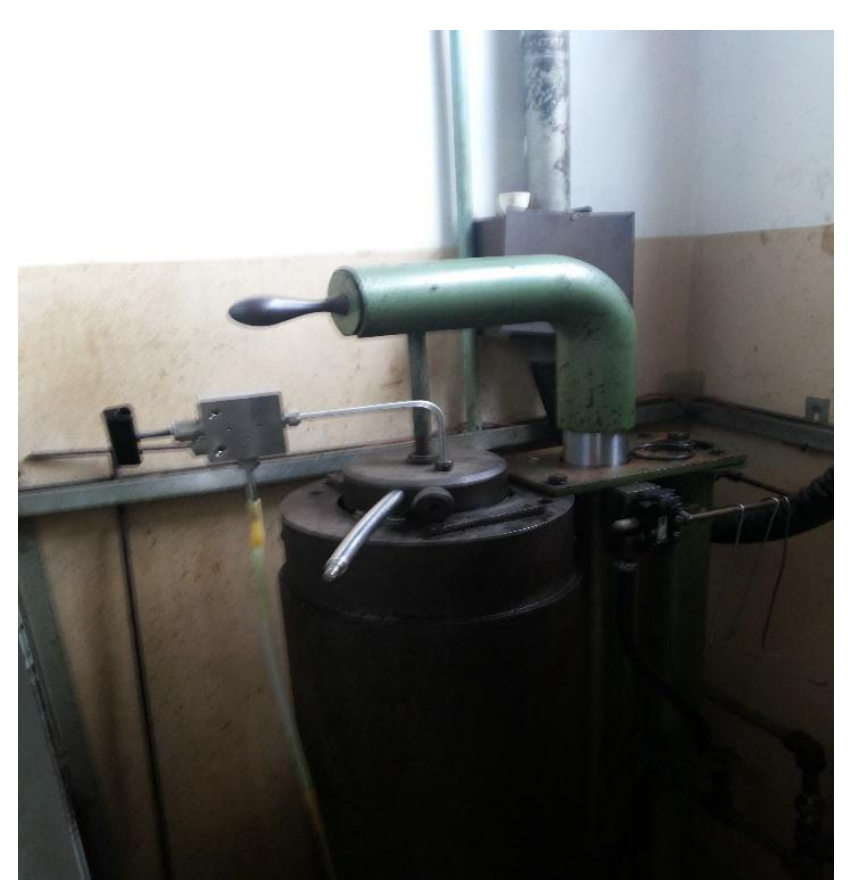

Figura 40. Prensa isostática a frio com capacidade para 700 MPa (100000 psi).

Neste método, aplica-se pressão simultaneamente e igualmente em todas as direções do corpo de prova. A amostra é devidamente embalada a vácuo e armazenada em um receptáculo que é mergulhado num banho fluído (água ou óleo), situado num vaso de pressão, onde o fluído é submetido à pressão de modo a exercer pressão isostática sobre a amostra em todas as direções. 


\section{RESULTADOS E DISCUSSÃO}

Neste capítulo serão apresentados todos os resultados obtidos neste trabalho, tanto aqueles relacionados com a caracterização dos materiais de partida quanto dos compactados obtidos. Os resultados serão discutidos e correlacionados com a literatura publicada, sempre que possível, seguindo as etapas como apresentada no capítulo anterior.

\subsection{Primeira etapa, caracterização dos pós}

A primeira etapa constituiu na caracterização dos pós utilizados, vide Tab. 9. A amostra do pó de níquel foi analisada quimicamente por fluorescência de raios X por dispersão de comprimento de onda "do inglês" wavelength dispersion $X$ ray diffraction fluorescence - WDXRF, apresentou resultados conforme mostrados na Tab. 10, com teor de níquel maior que $99,2 \%$ e 0,8 \% de outros elementos, principalmente magnésio, silício e flúor com $0,3 \pm 0,05 \%$.

Tabela 9. Características dos pós utilizados no presente trabalho.

\begin{tabular}{cccc}
\hline Pó & Grau de pureza (\%) & $\begin{array}{c}\text { Tamanho mediano } \\
\text { de partícula }(\mu \mathrm{m})\end{array}$ & Fabricante \\
\hline $\mathbf{N i}$ & 99,8 & $<44$ & $\begin{array}{c}\text { CRQ - Cromato Prod. } \\
\text { Químicos Ltda. }\end{array}$ \\
\hline $\mathbf{C u}$ & 99,9 & $<25$ & Combustol Metalpó \\
\hline
\end{tabular}

O pó de níquel foi observado no microscópio eletrônico de varredura e teve a composição química determinada também por espectroscopia de energia dispersiva EDS, cujo espectro é mostrado na Fig. 41. Por EDS detectou-se os picos de um único elemento, o níquel, em sua composição química, vide Fig. 41. 
Tabela 10. Resultados de análise química semi-quantitativa (\% em massa) obtidos no ensaio de fluorescência de raios $\mathrm{X}$ por dispersão de comprimento de onda, em uma amostra do pó de níquel utilizado neste trabalho.

\begin{tabular}{cc}
\hline Elementos & (\% em massa) \\
\hline $\mathrm{Ni}$ & $99,2 \pm 0,5$ \\
\hline $\mathrm{F}$ & $0,30 \pm 0,05$ \\
\hline $\mathrm{Mg}$ & $0,16 \pm 0,05$ \\
\hline $\mathrm{Si}$ & $0,16 \pm 0,05$ \\
\hline $\mathrm{Co}$ & $0,09 \pm 0,03$ \\
\hline $\mathrm{Fe}$ & $0,09 \pm 0,03$ \\
\hline $\mathrm{Ca}$ & $<0,03$ \\
\hline $\mathrm{Cr}$ & $<0,03$ \\
\hline $\mathrm{S}$ & $<0,03$ \\
\hline $\mathrm{Zr}$ & $<0,03$
\end{tabular}

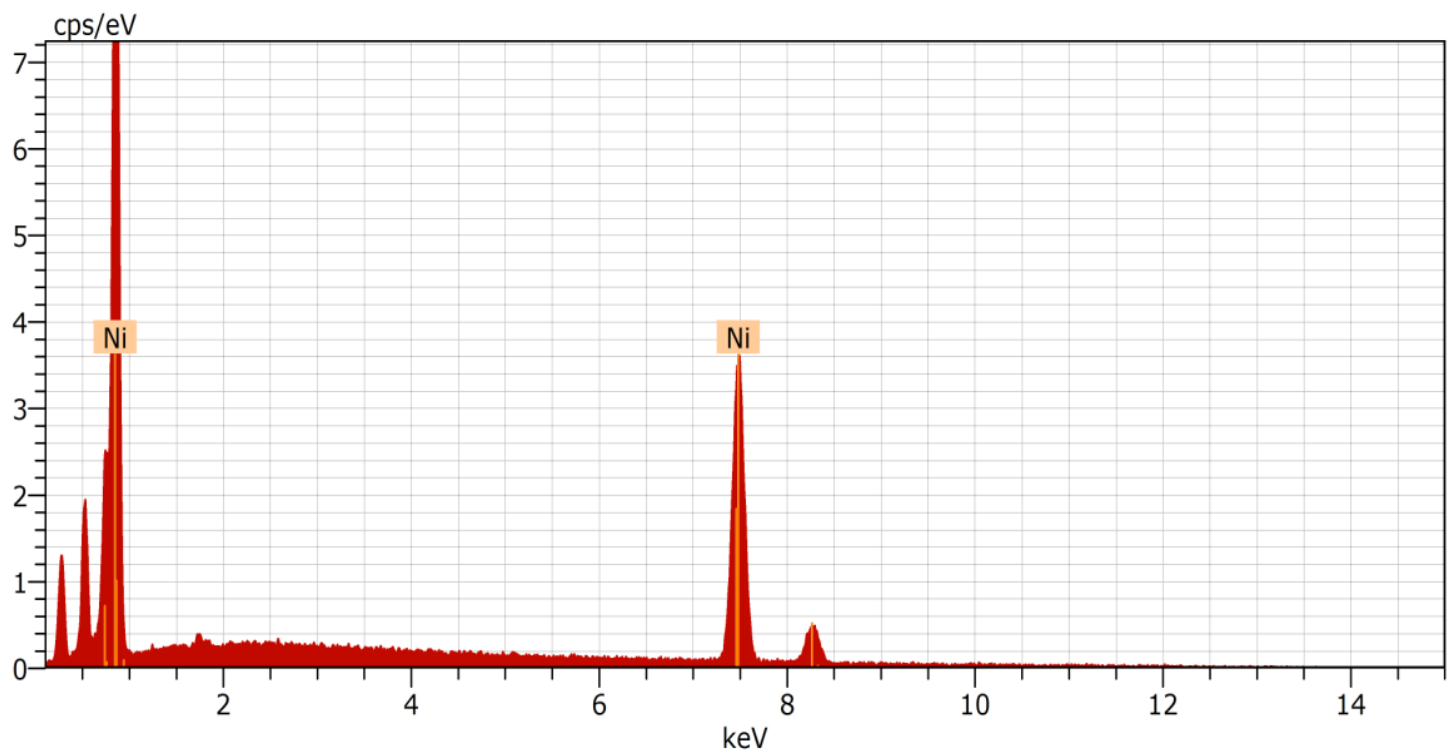

Figura 41. Espectro de energia dispersiva (EDS) obtido no microscópio eletrônico de varredura do pó de níquel usado neste trabalho.

O pó de níquel foi observado ainda conforme o ensaio de distribuição do tamanho de partícula, conforme a Fig. 42 mostra a curva de distribuição de tamanho de partícula obtida, sendo que o tamanho mediano de partícula de pó de níquel encontrado foi de $23,8 \mu \mathrm{m}$. 


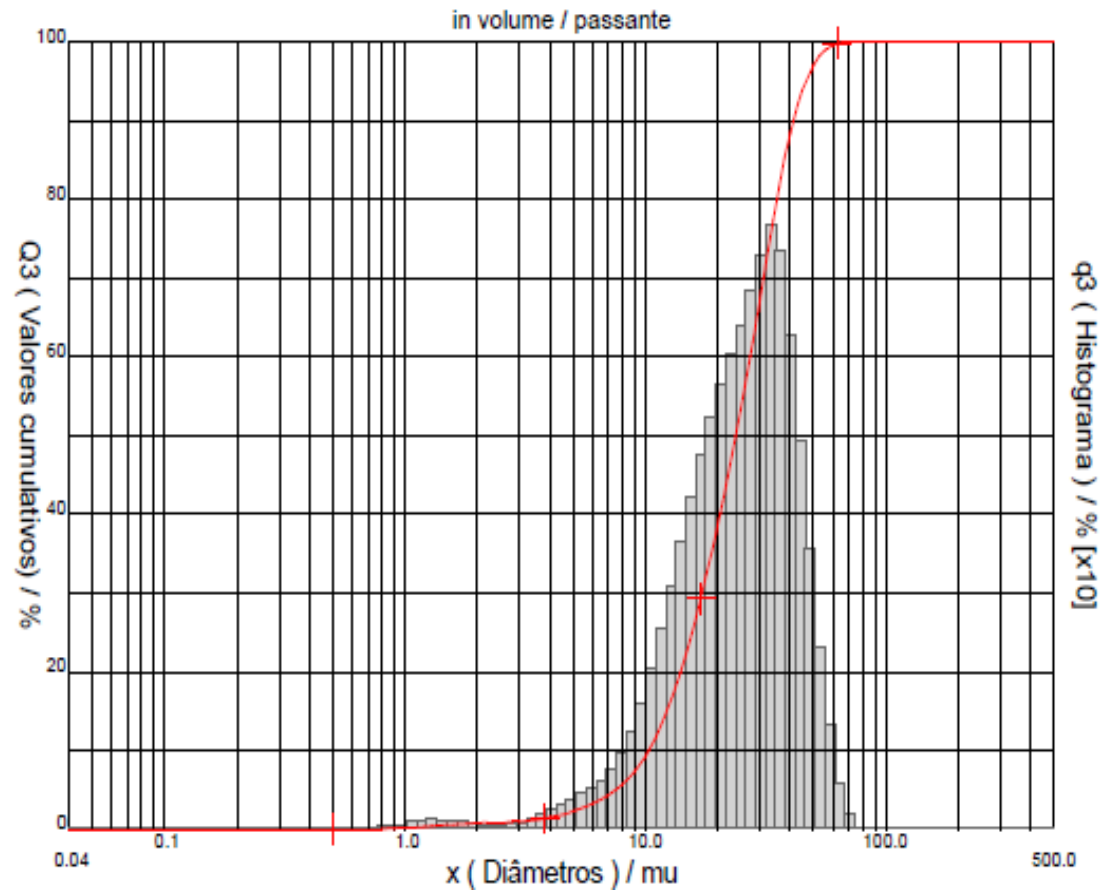

Figura 42. Curva da distribuição granulométrica do pó de níquel. $D_{10 \%}=10,29 \mu \mathrm{m}$. $D_{50 \%}=23,80 \mu \mathrm{m}$. $\mathrm{D}_{90 \%}=41,31 \mu \mathrm{m}$.

Através da microscopia eletrônica de varredura realizada em uma amostra do pó de níquel aderido a uma fita carbono, pode-se observar Imagem de elétrons retro-espalhados mostrando o aspecto morfológico arredondado do pó de níquel, vide Fig. 43. É possível identificar que as partículas são predominantemente equiaxiais e arredondadas.

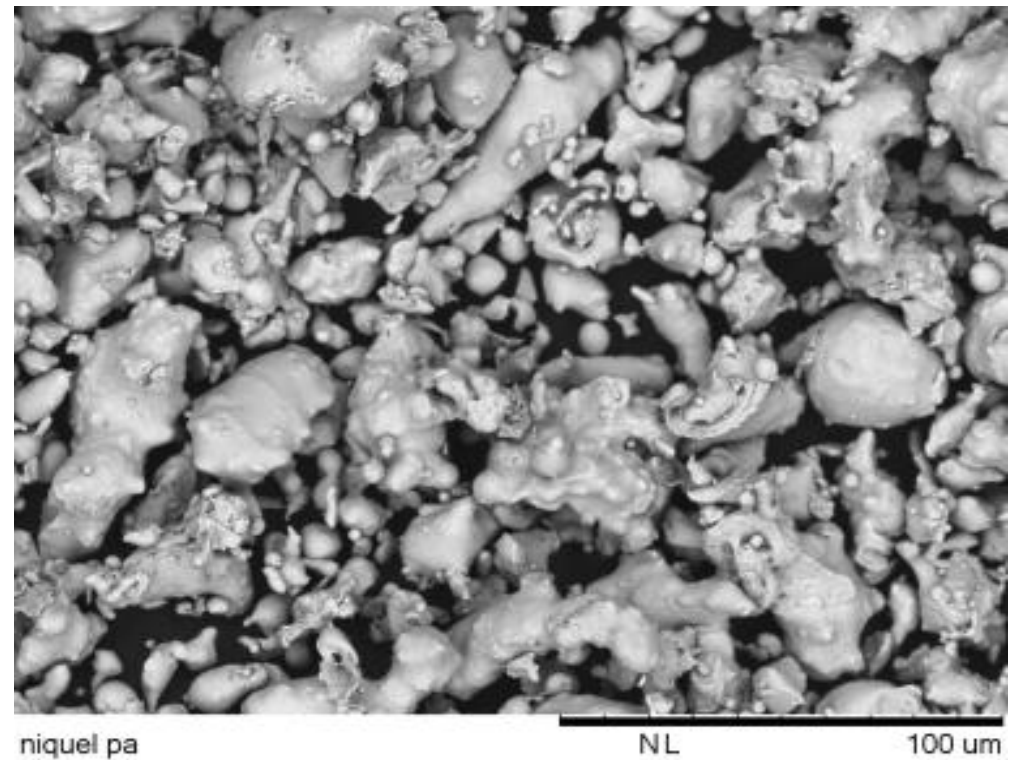

Figura 43. Microscopia eletrônica de varredura em uma amostra do pó de níquel utilizado, aderido a uma fita carbono. 
Resultados dos ensaios realizados no pó de cobre apresentados pelo fornecedor Combustól Metalpó. A Tab. 11 mostra os resultados de análise química (\% em massa), do pó de cobre EF-98S utilizado neste trabalho, segundo o fornecedor (lasi, 2014), juntamente com outras especificações mostradas nas Tabs. 12 e 13.

Tabela 11. Resultados de análise química (\% em massa), do pó de cobre EF-98S utilizado neste trabalho, segundo o fornecedor (lasi, 2014).

\begin{tabular}{ccc}
\hline Elementos & Mínimo & Máximo \\
\hline $\mathrm{Cu}$ & 91,5 & 94,5 \\
\hline $\mathrm{Mn}$ & 1,0 & 1,5 \\
\hline $\mathrm{Fe}$ & 3,2 & 4,8 \\
\hline $\mathrm{Al}(\mathrm{ppm})$ & 800 & 1200 \\
\hline
\end{tabular}

Tabela 12. Resultado de ensaios de densidade aparente e escoabilidade efetuados no pó de cobre EF-98S utilizado neste trabalho (Iasi, 2014).

\begin{tabular}{ccc}
\hline Descrição & Mínimo & Máximo \\
\hline Densidade aparente $\left(\mathrm{g} / \mathrm{cm}^{3}\right)$ & 2,80 & 3,2 \\
\hline Escoabilidade $(\mathrm{s} / 50 \mathrm{~g})$ & - & 40 \\
\hline
\end{tabular}

Tabela 13. Distribuição granulométrica do pó de cobre EF-98S utilizado neste trabalho, segundo o fornecedor (Iasi, 2014).

\begin{tabular}{ccc}
\hline Malha (mesh) & Mínimo & Máximo \\
\hline+080 & - & 2,0 \\
\hline+100 & - & bal. \\
\hline+150 & - & bal. \\
\hline+200 & - & bal. \\
\hline+325 & - & bal. \\
\hline-325 & 40,0 & 60,0
\end{tabular}

\subsection{Segunda etapa}

A segunda etapa deste trabalho de pesquisa foi feita com o objetivo de avaliar o desempenho do compactado em relação à densificação com o tempo de 
sinterização. Para tanto manteve-se uma mesma pressão de compactação 195 $\mathrm{MPa}$ e a temperatura de sinterização $600{ }^{\circ} \mathrm{C}$, variando-se o tempo de sinterização de $2 \mathrm{~h}$ a $24 \mathrm{~h}$.

Todas as amostras compactadas apresentaram uma redução média de densidade antes e após tratamento, da ordem de $0,09 \mathrm{~g} / \mathrm{cm}^{3}$ para um tempo de sinterização de $3 \mathrm{~h}$ e $0,26 \mathrm{~g} / \mathrm{cm}^{3}$ para um tempo de sinterização de $24 \mathrm{~h}$. $O$ gráfico referente à densidade das amostras sinterizadas a $600{ }^{\circ} \mathrm{C}$ é mostrado na Fig. 44. A Tab. 14 mostra a variação média da densidade com o tempo de sinterização a $600{ }^{\circ} \mathrm{C}$ (média de 3 amostras). A densificação é relativa entre um tempo de sinterização em h e o próximo intervalo.

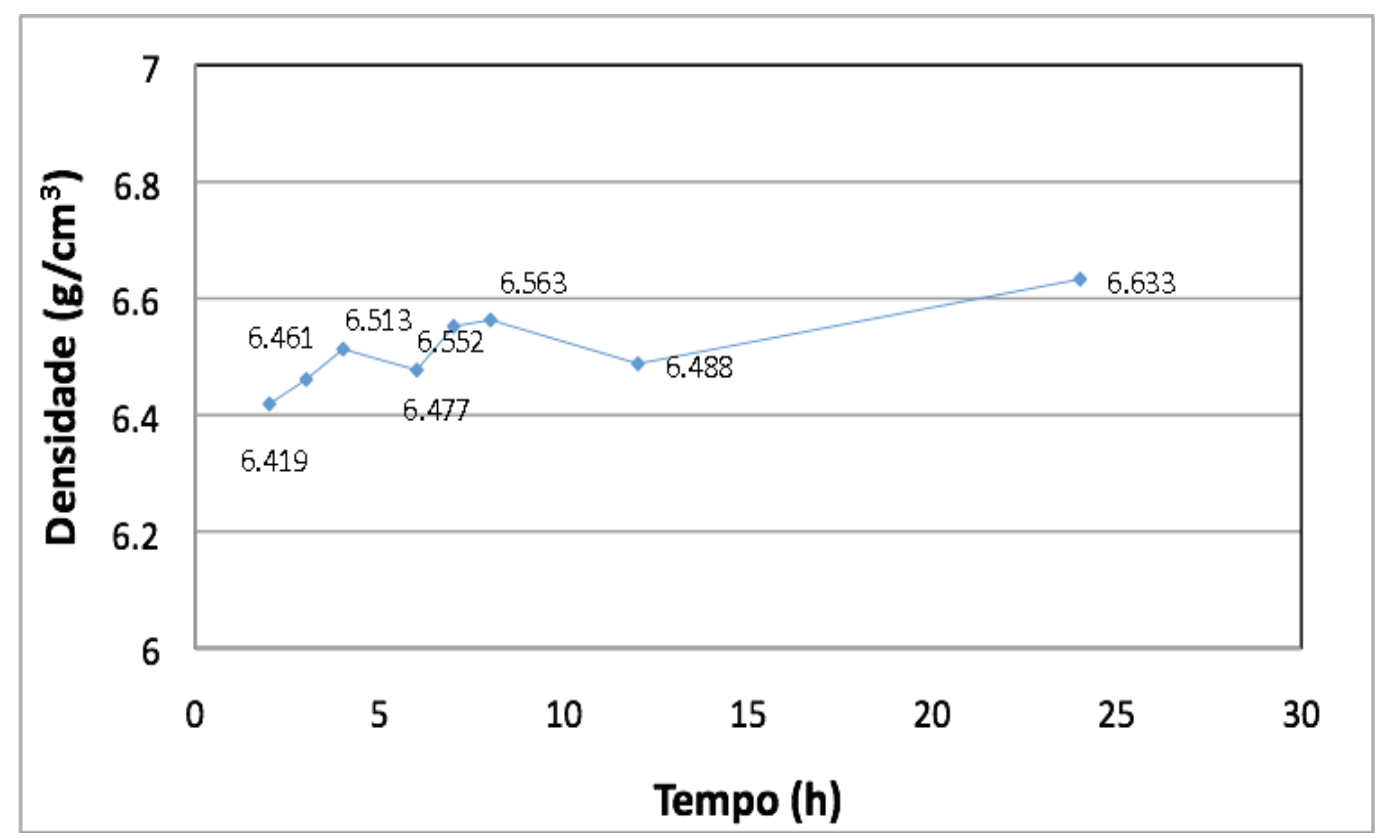

Figura 44. Variação da densidade dos compactados com o tempo em h na sinterização a $600^{\circ} \mathrm{C}$ em atmosfera protegida com cavacos de titânio.

O ensaio de porosimetria de mercúrio em amostra compactada a $206 \mathrm{MPa}$ e sinterizada a $600{ }^{\circ} \mathrm{C}$ por $24 \mathrm{~h}$, apresentou uma porosidade de 20,08\%. Está foi a única amostra avaliada pela porosimetria de mercúrio.

Duas amostras foram embutidas em resina e preparadas para análise de microscopia eletrônica de varredura (MEV). Essas amostras foram atacadas com água régia a $1 \%$ por $1 \mathrm{~s}$ revelando uma microestrutura conforme mostrado nas Fig. 45(a) e 45(b). A porosidade observada em princípio seria do tipo interconectada, confirmando os dados obtidos no ensaio de porosimetria de mercúrio que já apontava para este tipo de porosidade. 
Tabela 14. Variação média da densidade com o tempo de sinterização a $600{ }^{\circ} \mathrm{C}$ (média de 3 amostras). A densificação é relativa entre um tempo de sinterização em h e o próximo intervalo.

\begin{tabular}{|c|c|c|c|}
\hline Tempo (h) & $\begin{array}{c}\text { Densidade } \\
\text { media }\left(\mathrm{g} / \mathrm{cm}^{3}\right)\end{array}$ & $\begin{array}{c}\text { Aumento na densidade } \\
\text { media }\left(\mathrm{g} / \mathrm{cm}^{3}\right)\end{array}$ & $\begin{array}{l}\text { Densificação } \\
(\%)\end{array}$ \\
\hline 0 & 6,479 & - & - \\
\hline 2 & 6,536 & 0,058 & 0,89 \\
\hline 3 & 6,559 & 0,080 & 1,24 \\
\hline 4 & 6,497 & 0,018 & 0,28 \\
\hline 5 & 6,563 & 0,084 & 1,30 \\
\hline 6 & 6,618 & 0,140 & 2,16 \\
\hline 7 & 6,602 & 0,124 & 1,91 \\
\hline 8 & 6,577 & 0,098 & 1,51 \\
\hline 12 & 6,616 & 0,138 & 2,12 \\
\hline 24 & 6,659 & 0,180 & 2,78 \\
\hline
\end{tabular}

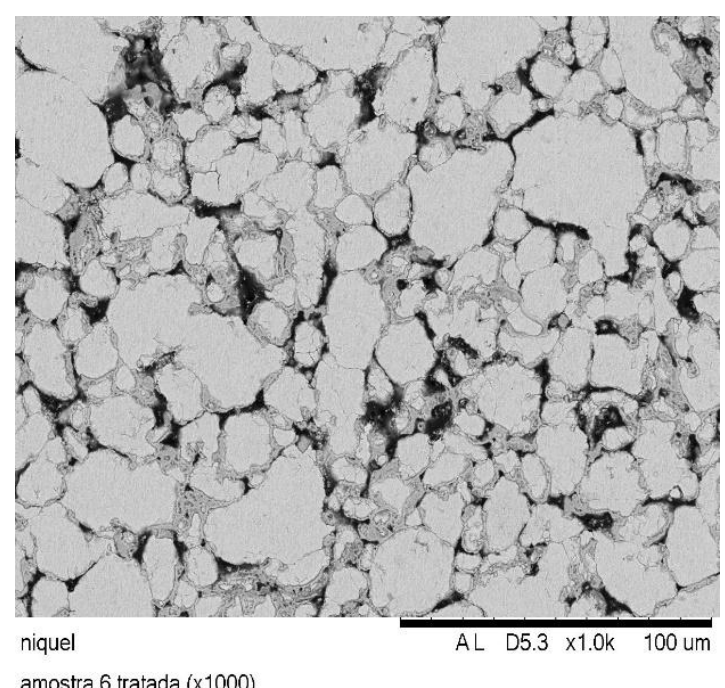

a)

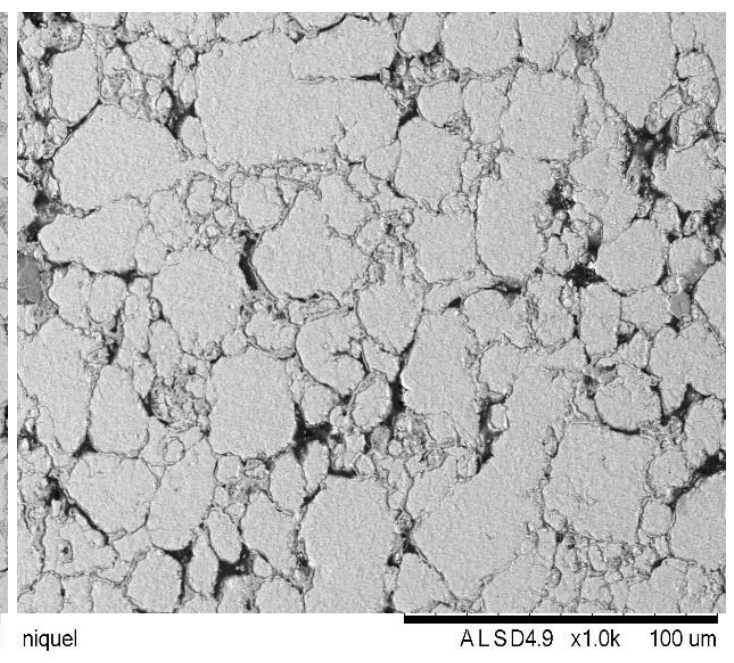

b)

Figura 45. (a) Micrografia eletrônica de varredura com elétrons retro-espalhados do compactado de níquel sinterizada por $3 \mathrm{~h}$ mostrando os grãos de níquel contraste claro, fase em contorno de grão contraste cinza e porosidade contraste escuro. (b) Micrografia eletrônica de varredura com elétrons retro-espalhados do compactado de níquel sinterizada por $5 \mathrm{~h}$. Ataque água régia.

O ensaio de compressão foi realizado em amostras compactadas e sinterizadas a $600{ }^{\circ} \mathrm{C}$ por diferentes tempos de sinterização. Foram selecionadas quatro amostras com diferentes tempos de sinterização. Com os resultados 
obtidos pode-se observar um aumento na resistência mecânica do material com o aumento do tempo de sinterização, conforme mostrado na Fig. 46. Para um tempo de sinterização de $24 \mathrm{~h}$ a $600^{\circ} \mathrm{C}$, a carga de compressão do compactado foi de $5645 \mathrm{kgf}$, dando um limite de compressão de $367 \mathrm{MPa}$, antes que o compactado esboroasse.

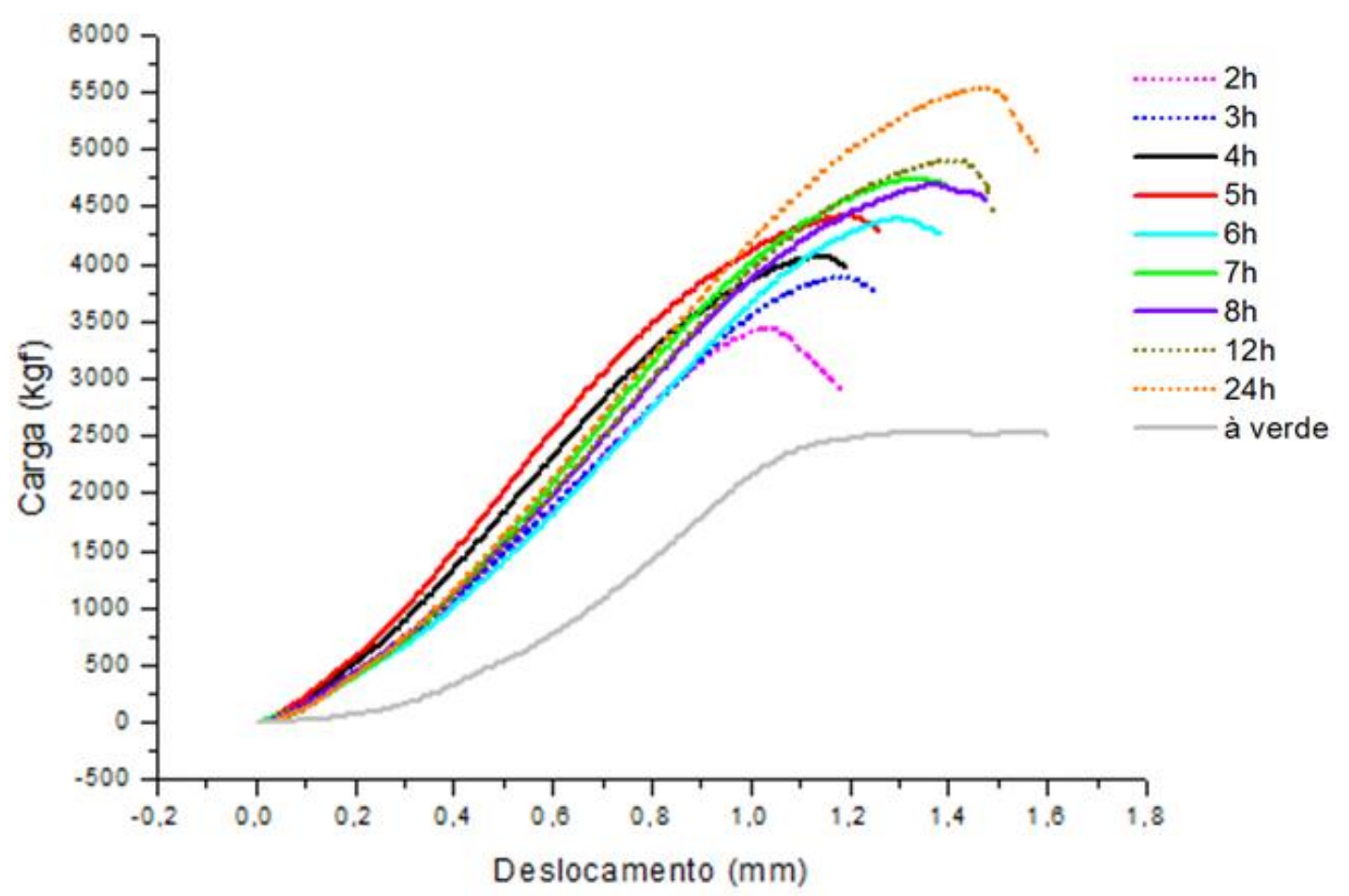

Figura 46. Gráfico da variação da carga de compressão com o deslocamento do travessão em amostras de compactado de níquel à verde e com diferentes tempos de sinterização a $600^{\circ} \mathrm{C}$.

\subsection{Terceira etapa}

Nesta etapa com aplicação de 10 diferentes pressões de compactação, a saber, $75 \mathrm{MPa}, 150 \mathrm{MPa}, 225 \mathrm{MPa}, 300 \mathrm{MPa}, 375 \mathrm{MPa}, 450 \mathrm{MPa}, 525 \mathrm{MPa}$, $600 \mathrm{MPa}, 675 \mathrm{MPa}$ e $800 \mathrm{MPa}$ verificou-se respectivamente também o aumento da densidade verde e após sinterização do compactado conforme mostram os gráficos das Figs. 47 e 48 . Os ciclos de aquecimento foram de $600^{\circ} \mathrm{C}$ por $4 \mathrm{~h}$ e de $600{ }^{\circ} \mathrm{C}$ por $4 \mathrm{~h}+8 \mathrm{~h}$ de patamar. A atmosfera utilizada na sinterização das amostras foi de hidrogênio $(20 \mathrm{cmHg})$. Durante o patamar foi observada uma pequena queda na pressão, passando dos $20 \mathrm{cmHg}$ iniciais para $24 \mathrm{cmHg}$, podendo indicar uma redução do pó de níquel. 


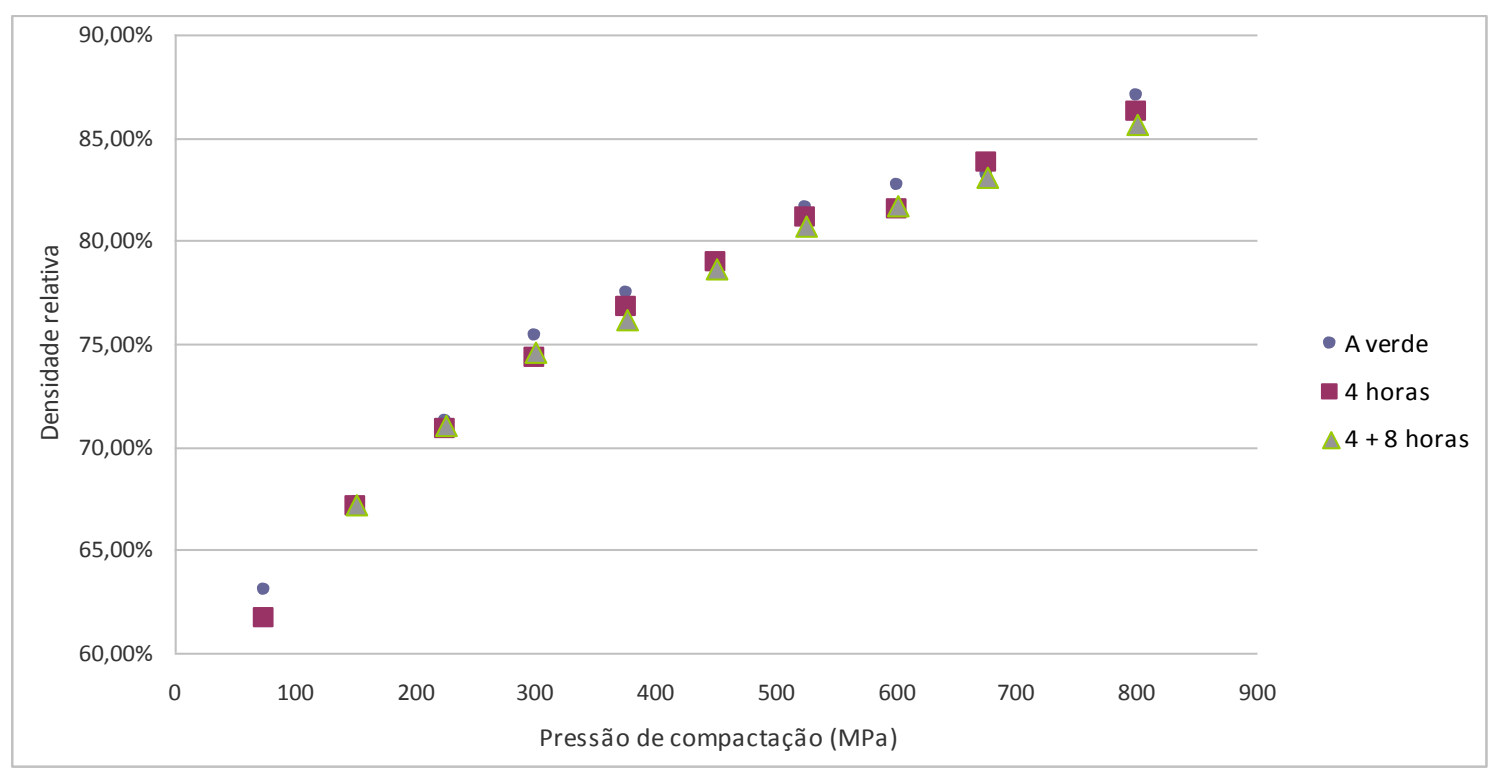

Figura 47. Gráfico de compressibilidade referente à compactação em 10 amostras de níquel com diferentes pressões de compactação.

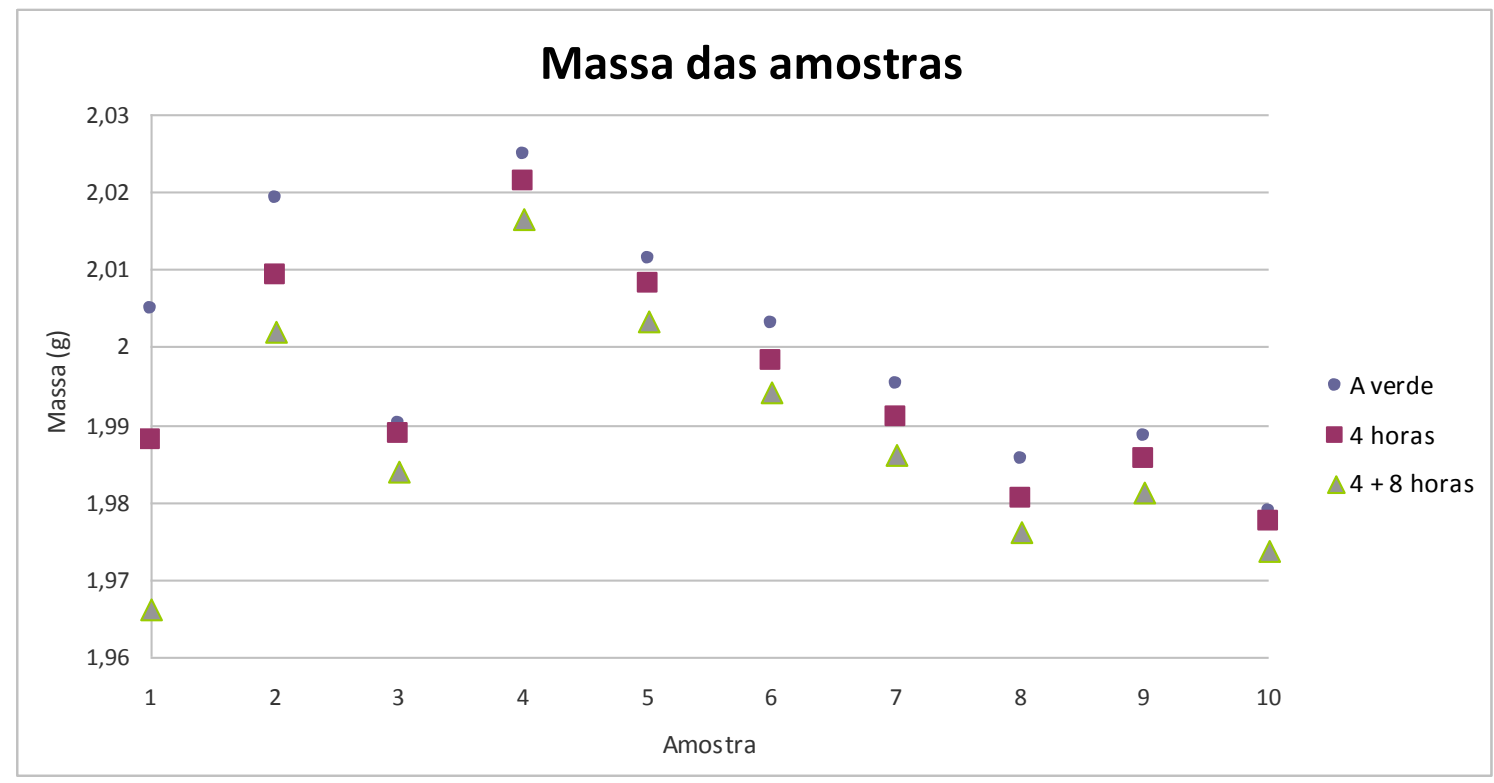

Figura 48. Gráfico referente à massa das amostras compactadas antes e após sinterização por um período de 4 e 8 horas de patamar.

Foi observada uma redução na massa das amostras após 4 horas de patamar, um indicativo da redução de óxido de níquel durante o ciclo térmico. Para o cálculo da densidade relativa foi usado para o níquel a densidade 8,902 $\mathrm{g} / \mathrm{cm}^{3}$. 
Mantendo-se o patamar de $600 \stackrel{\circ}{\circ}$ por um período de $4 \mathrm{~h}+8 \mathrm{~h}$, não foi observado sinal de mudanças significativas na densificação das amostras compactadas, independentemente da pressão de compactação aplicada.

\subsection{Quarta etapa}

As amostras após compactação na prensa uniaxial a $195 \mathrm{MPa}$, foram seladas em invólucros de plástico utilizando-se uma seladora a vácuo. Estas amostras foram colocadas submersas em fluido dentro da prensa isostática e submetidas a uma compressão de $206 \mathrm{MPa}$ (30000 psi). Após, as mesmas foram sinterizadas em fornos tubulares com atmosfera de alto vácuo, hidrogênio e argônio em temperatura de $600{ }^{\circ} \mathrm{C}$ por $24 \mathrm{~h}$.

Estas amostras foram submetidas a ensaio de compressão, conforme mostrado no gráfico da Fig. 49. As cargas de compressão muito mais baixas da ordem de $2750 \mathrm{kgf}$, que as obtidas com o compactado sinterizado com atmosfera com cavacos de titânio, etapa 2, (Figura 46) pode ser devido a presença de uma camada externa muito porosa conforme será comentado adiante.

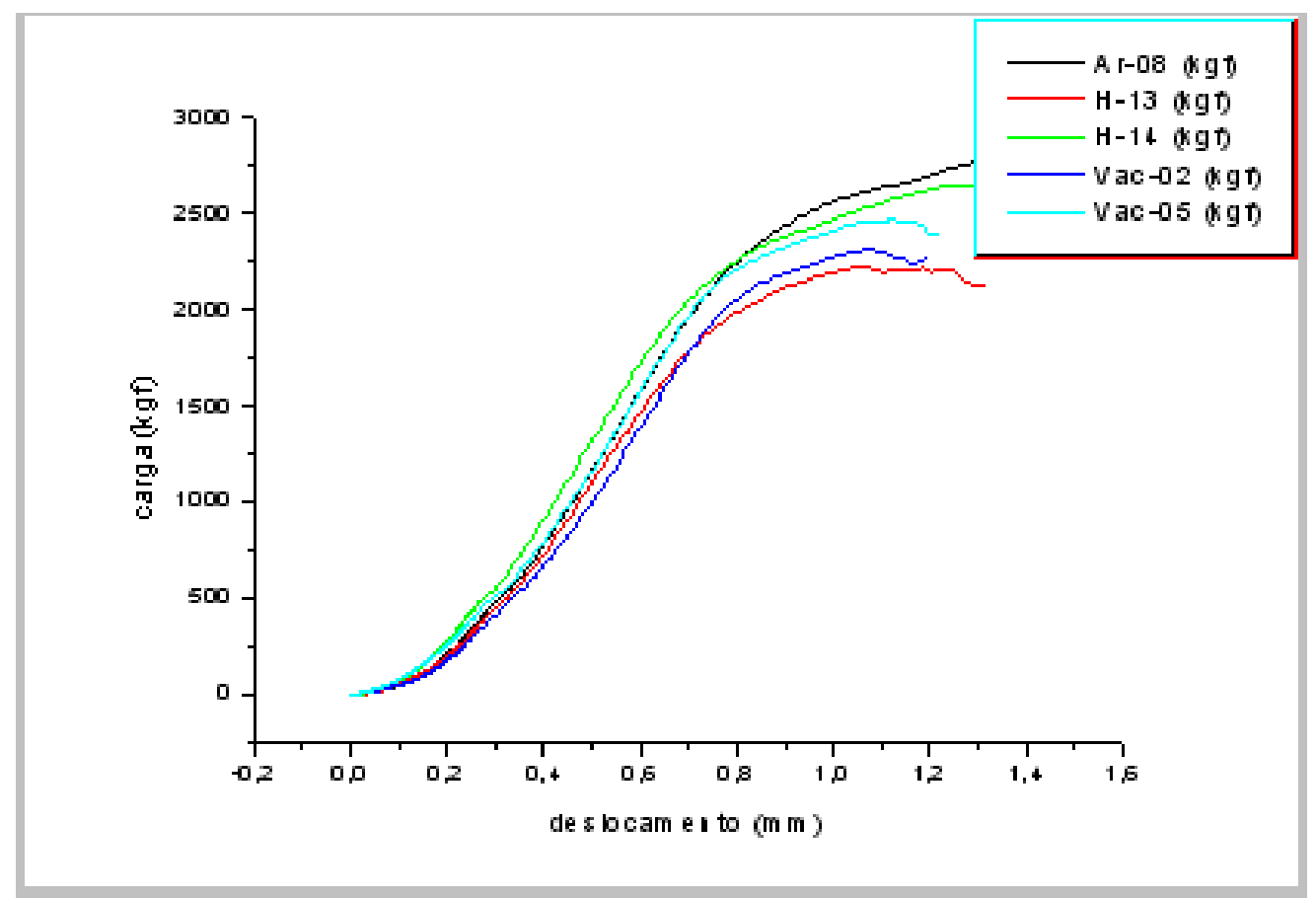

Figura 49. Gráfico da variação da carga de compressão com o deslocamento do travessão em amostras de compactado de níquel no tempo de $24 \mathrm{~h}$ de sinterização a $600{ }^{\circ} \mathrm{C}$ e compactada a $206 \mathrm{MPa}$ em prensa isostática, em atmosferas controladas de argônio, hidrogênio e vácuo. 
As figuras 50 (a) e 50(b) apresentam as micrografias obtidas no microscópio óptico das amostras do compactado de níquel após ensaio de sinterização de 24 h em atmosfera de argônio. Observa-se que houve sinterização no centro do compactado sendo que as bordas ficaram muito porosas, conforme é mostrado na Fig. 50. Durante o ensaio mecânico de compressão do compactado, esta camada externa porosa cedeu em baixas cargas, indicando que o ensaio tinha de ser interrompido. Provavelmente, se o ensaio de compressão fosse continuado, seria alcançado níveis maiores de limite de resistência a compressão.

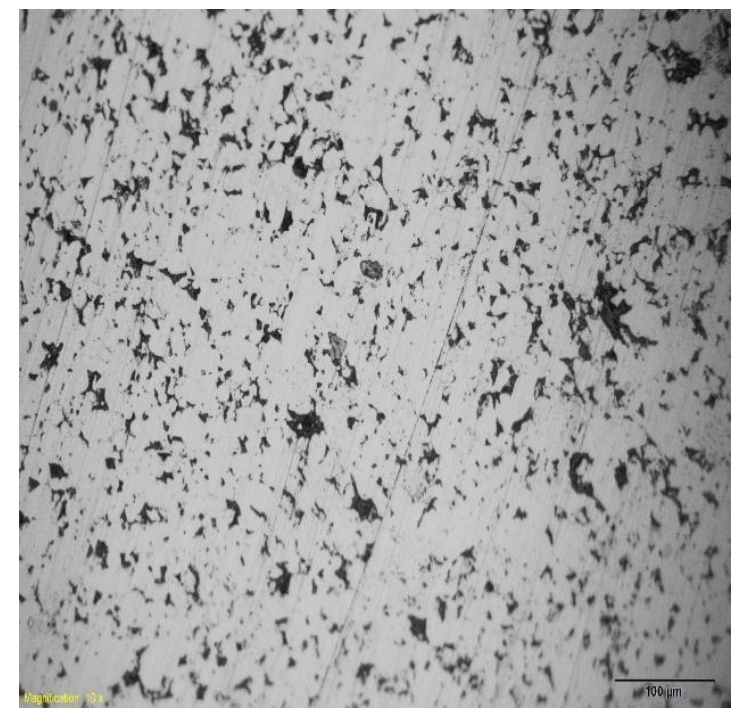

a)

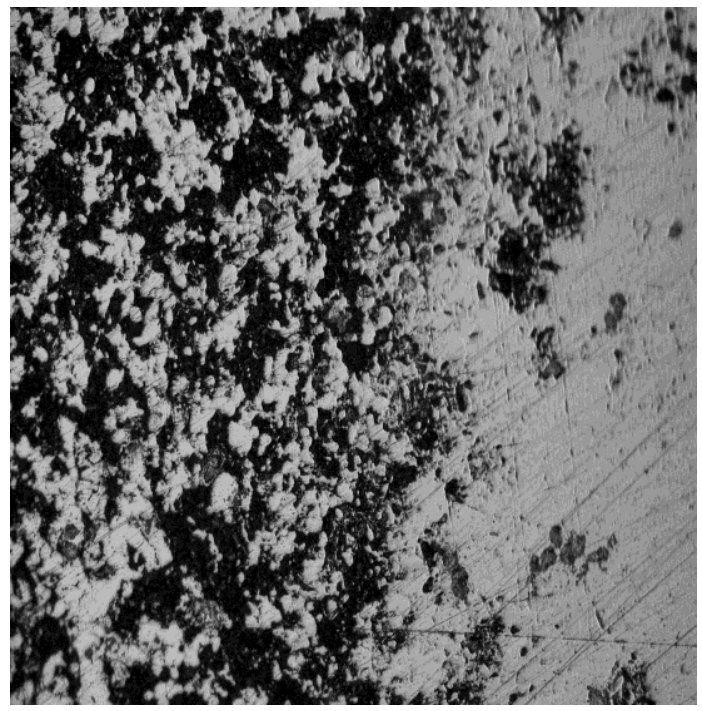

b)

Figura 50. (a) Micrografia óptica do centro do compactado de níquel após tempo de $24 \mathrm{~h}$ de sinterização, compactado em prensa isostática, sinterizada a $600{ }^{\circ} \mathrm{C}$ em atmosfera controlada de argônio. (b) Micrografia óptica da borda do compactado de níquel mostrando uma alta porosidade. Sem ataque.

As Figs. 51(a) e 51(b) mostram as micrografias obtidas no microscópio óptico das amostras de compactado de níquel após ensaio de sinterização de 24 $\mathrm{h}$ em atmosfera de hidrogênio. Observa-se que houve sinterização no centro do compactado sendo que as bordas ficaram muito porosas, semelhante ao ocorrido com os compactados em atmosfera de argônio, conforme é mostrado na Fig. 51.

As Fig. 52 (a) e 52 (b) apresentam as micrografias obtidas no microscópio óptico das amostras de compactado de níquel após ensaio de sinterização de 24 $\mathrm{h}$ em atmosfera de alto vácuo. Observa-se que houve sinterização no centro do compactado sendo que as bordas ficaram muito porosas, semelhante ao ocorrido 
com os compactados em atmosfera de argônio e hidrogênio, conforme é mostrado nas Fig. 50 e 51.

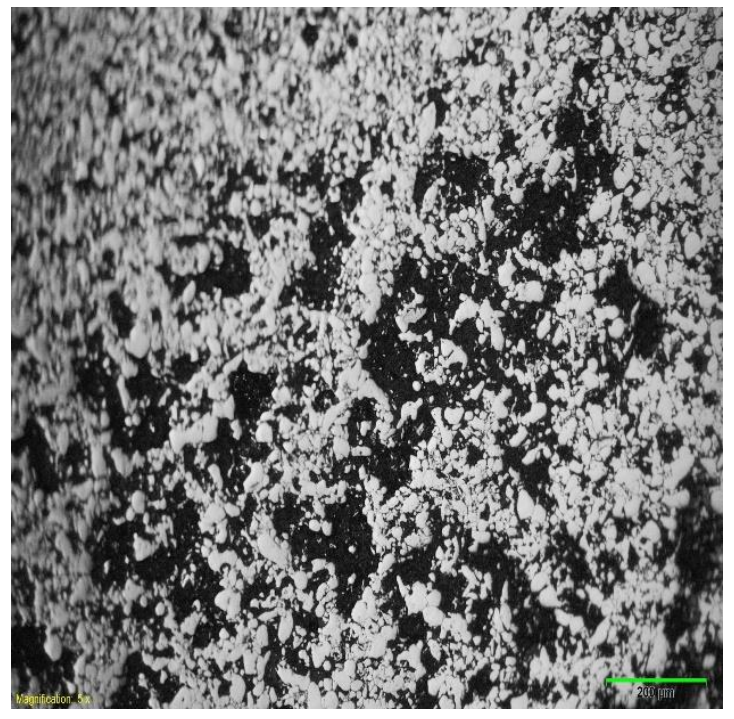

a)

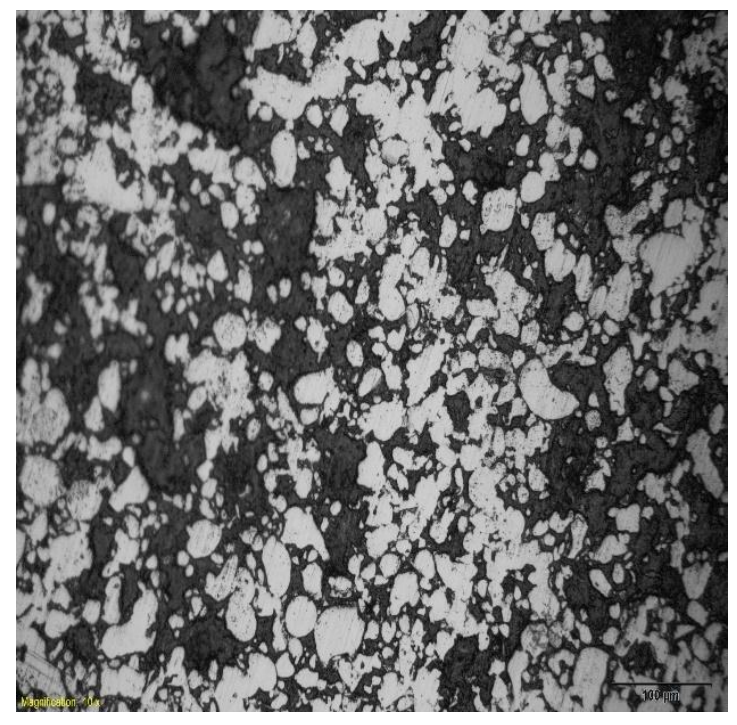

b)

Figura 51. (a) Micrografia óptica do centro do compactado de níquel após tempo de $24 \mathrm{~h}$ de sinterização, compactado em prensa isostática, sinterizada a $600{ }^{\circ} \mathrm{C}$ em atmosfera controlada de hidrogênio. (b) Micrografia óptica da borda do compactado de níquel mostrando alta porosidade. Sem ataque.

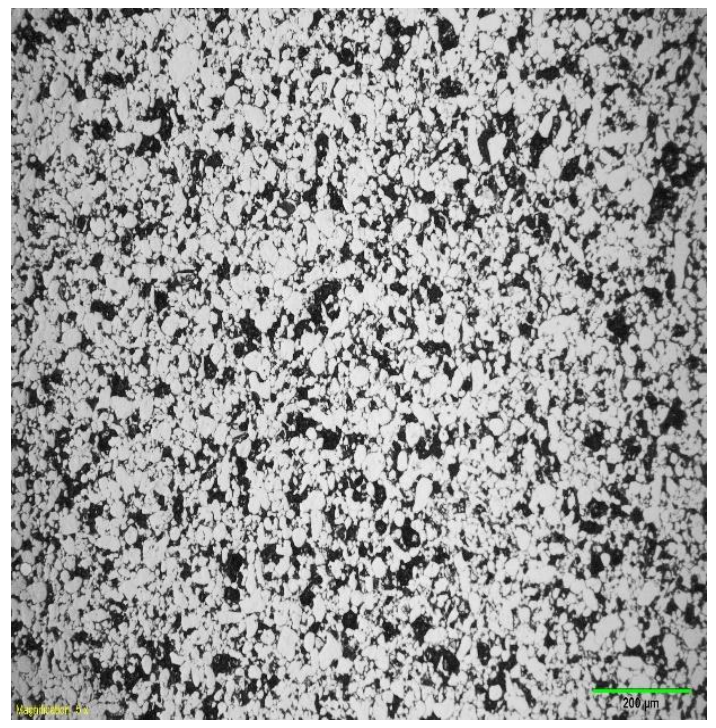

a)

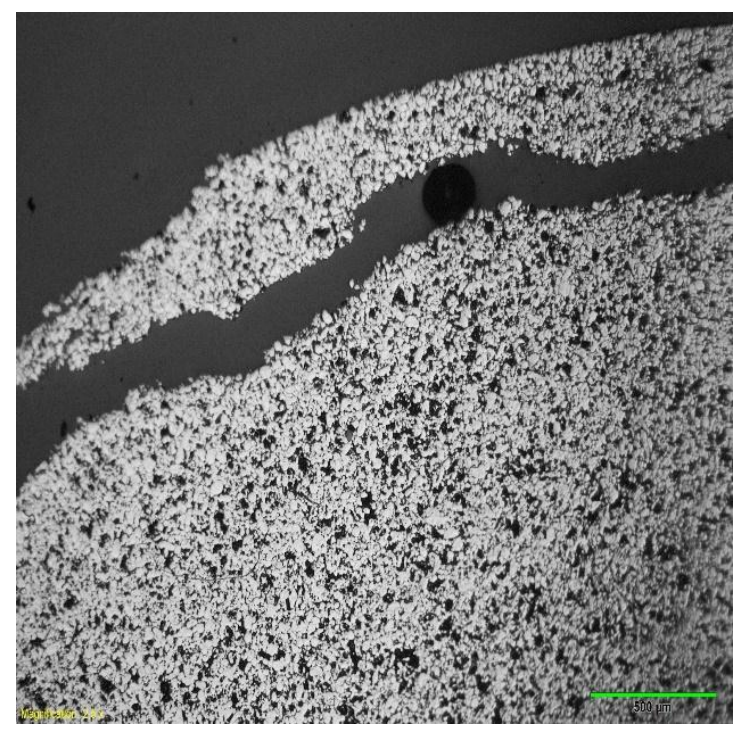

b)

Figura 52. (a) Micrografia óptica do centro do compactado de níquel após tempo de $24 \mathrm{~h}$ de sinterização, compactado em prensa isostática, sinterizada a $600{ }^{\circ} \mathrm{C}$ em atmosfera controlada de alto vácuo. (b) Micrografia óptica da borda do compactado de níquel mostrando uma alta porosidade e um destacamento da camada lateral externa. 


\subsection{Quinta etapa}

As amostras foram compactadas na prensa uniaxial e na prensa isostática e sinterizadas em forno contínuo a $1150 \stackrel{\circ}{\circ}$ com atmosfera de $70 \%$ de hidrogênio e 30\% de nitrogênio por 50 min, na empresa Combustol Metalpó. A atmosfera de hidrogênio é redutora e ajuda a eliminar óxido na superfície das partículas. $\mathrm{O}$ nitrogênio é usado como complemento para preenchimento da atmosfera do forno. Esta atmosfera é a mais utilizada, sendo considerada uma atmosfera limpa. Para esta etapa foi compactado o cobre utilizando-se 1,5 g de pó de cobre como material infiltrante, sendo que ele se infiltra no compactado de níquel por capilaridade. O pó de cobre foi compactado usando-se a mesma matriz já em uso neste trabalho para compactar o pó de níquel. A vantagem no emprego desta técnica é o aumento localizado da densidade em uma determinada região da peça. Segundo (Loberto, 2012), peças com densidade relativa inferior a $75 \%$ são consideradas de baixa densidade e acima de 90\%, de alta densidade. Em geral peças estruturais possuem densidade relativa que variam de 80 a 95\%. A Fig. 53 mostra o detalhe do disco compactado de cobre usado como material infiltrante na sinterização de amostras de níquel. A Fig. 54 mostra os compactados de níquel sinterizados com infiltração de cobre e com o núcleo em aço inoxidável AISI 304. Pode-se notar na Fig. 54, que houve um excesso de cobre pois as amostras sinterizadas apresentaram uma crosta na superfície superior do compactado. Isto também pode ser devido a um certo grau de oxidação do pó de cobre, podendo ter ocorrido antes, durante a estocagem do mesmo ou durante a sinterização.

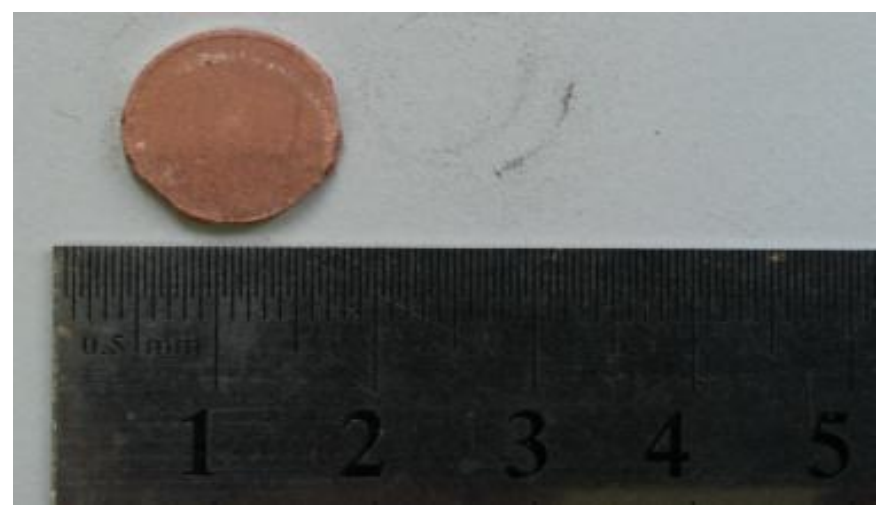

Figura 53. Compactado de cobre na forma de disco usado para a sinterização em dois corpos (níquel e cobre). 


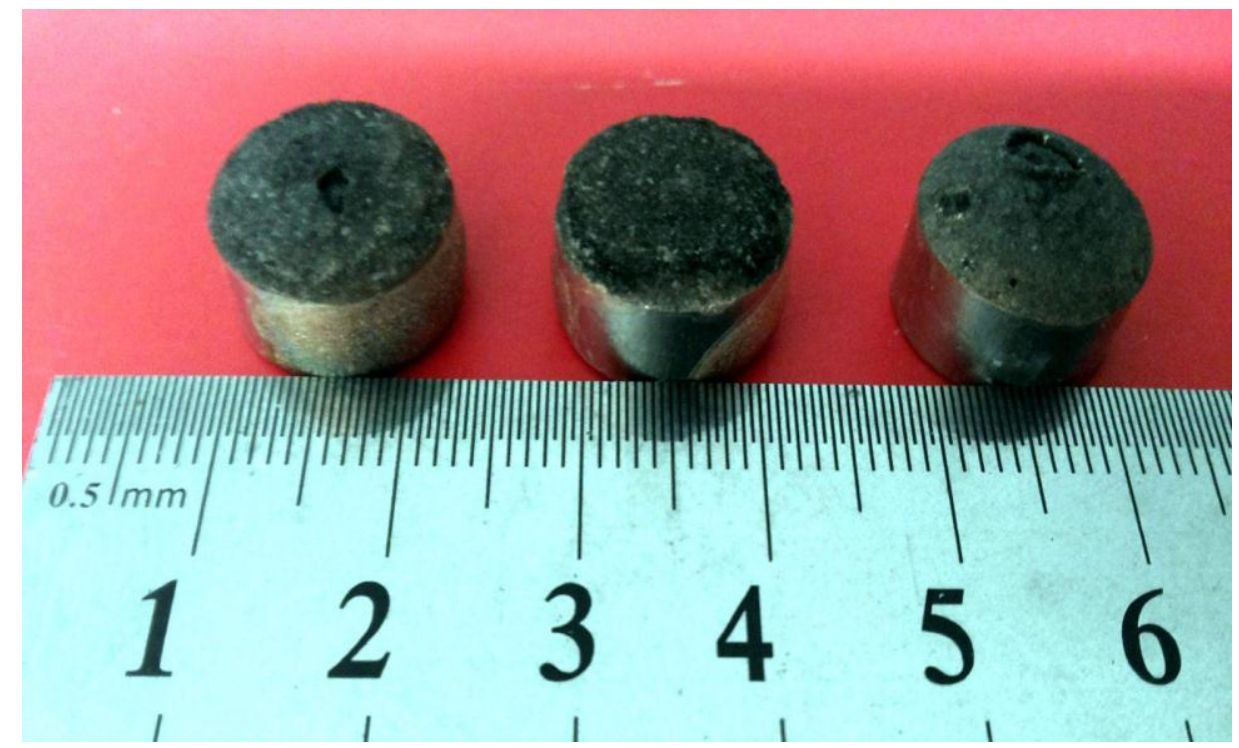

Figura 54. Compactados de níquel utilizado após infiltração com o cobre. Nota-se na superfície superior do compactado de níquel a presença de uma crosta de cobre. Este compactado já foi feito com o núcleo em aço AISI 304.

As Figs. 55 e 56, obtidas em microscópio óptico, mostram as microestruturas do material níquel com infiltração de cobre. As microestruturas foram analisadas sem ataque químico. Pode-se notar que houve infiltração de cobre evidenciada pela baixa porosidade conforme mostrada na Fig. 55 (a) e pela presença de ilhas e cobre dentro material, vide Fig. 56.

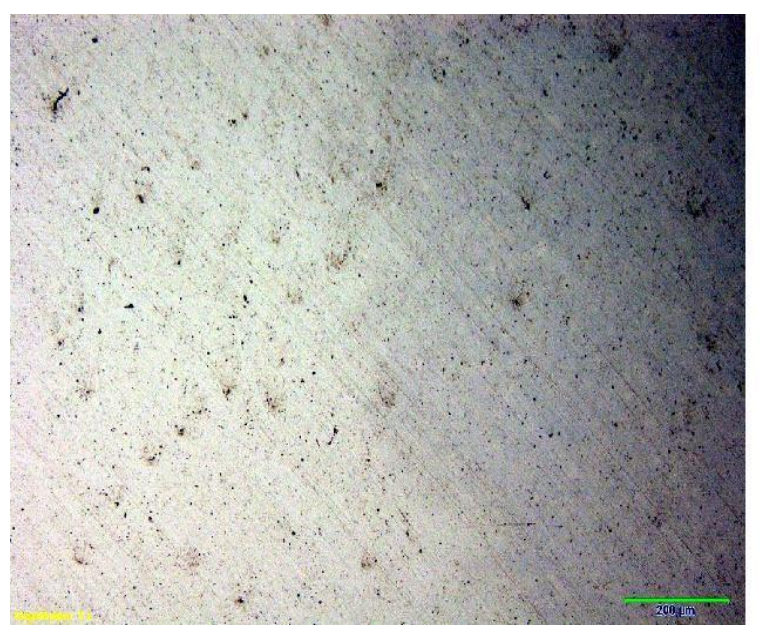

a)

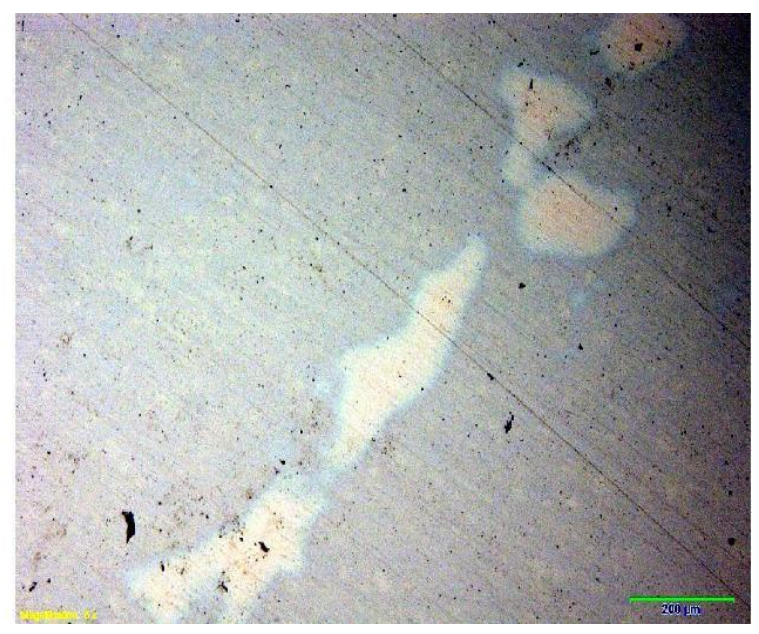

b)

Figura 55. (a) Micrografia óptica mostrando o aspecto do compactado de níquel com infiltração de cobre, evidenciando ainda a presença de poros. (b) Ilhas de cobre, contraste rosa, dentro do sinterizado de níquel. 


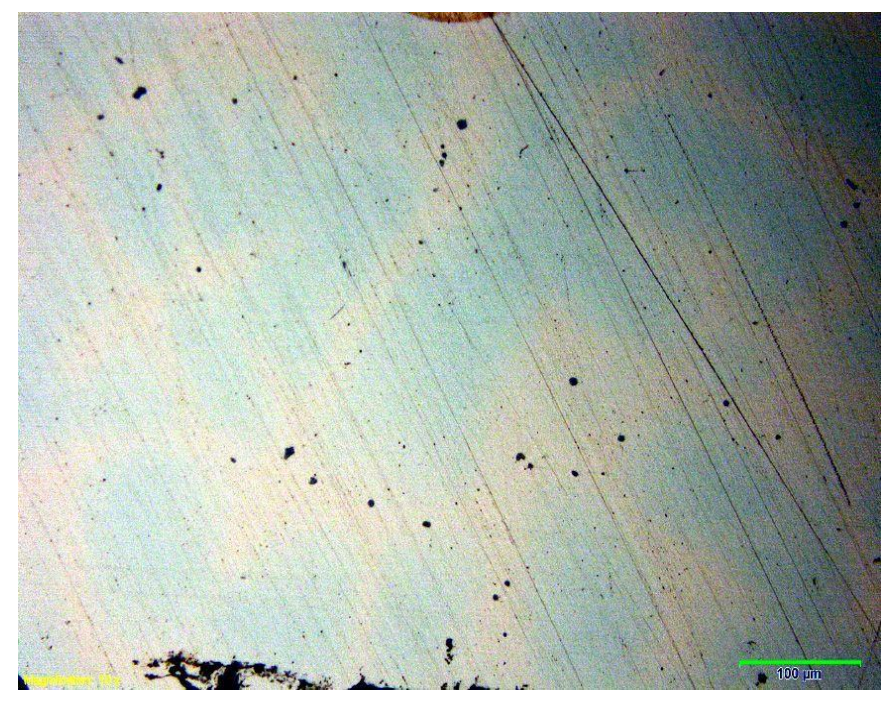

Figura 56. Micrografia óptica mostrando o aspecto do material com infiltração de cobre, nesta região o cobre está em fase contínua, contraste rosa, em níquel, contraste azul claro.

\subsection{Sexta etapa}

Na sexta etapa, quatro compactados de níquel foram montados com um núcleo em aço AISI 304, para simular a presença, sob alguma extensão, do núcleo de urânio. O cálculo utilizado para obter a massa do núcleo em aço AISI 304, simulando a presença do urânio no compactado, foi feito com base no esquema mostrado nas fig. 38 (a) e 38 (b).

As Figs. 57 e 58, obtidas em microscópio óptico, mostram interfaces do sinterizado de níquel com cobre e o núcleo em aço AISI 304. Em geral o compactado apresentou boa densidade, não havendo descontinuidades nas interfaces.

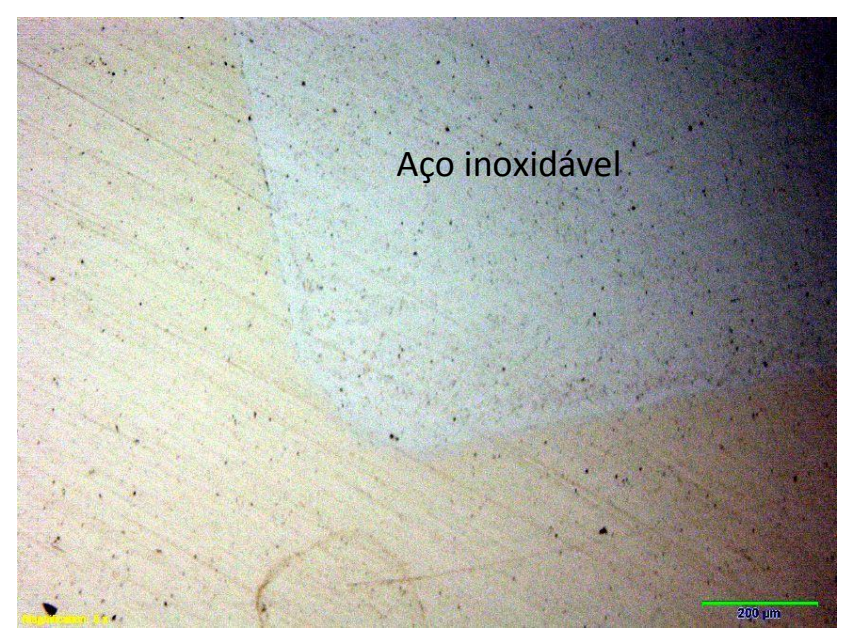

Figura 57. Interface entre o sinterizado ou invólucro de níquel e o núcleo de aço inoxidável AISI 304. 


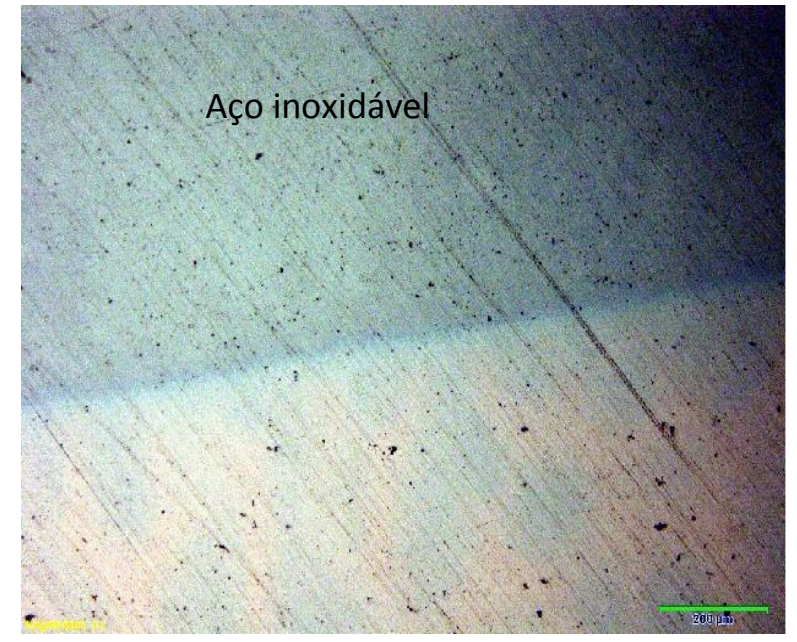

a)

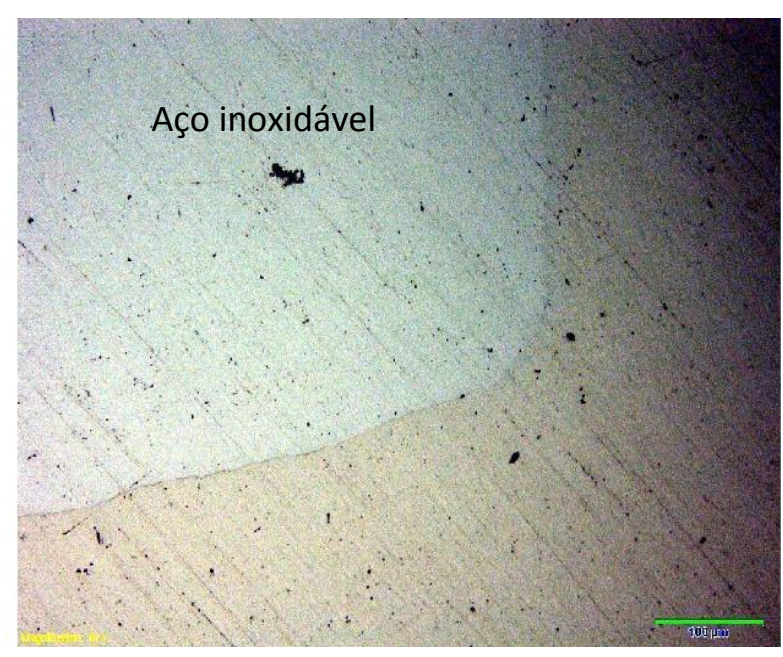

b)

Figura 58. Micrografia óptica mostrando interfaces níquel/cobre com o núcleo em aço AISI 304.

Entretanto, esta amostra apresentou uma trinca na lateral do compactado, mais provável tendo ocorrido a verde uma vez que a trinca tem origem na superfície em sentido ao núcleo, como pode ser visto na Fig. 59.

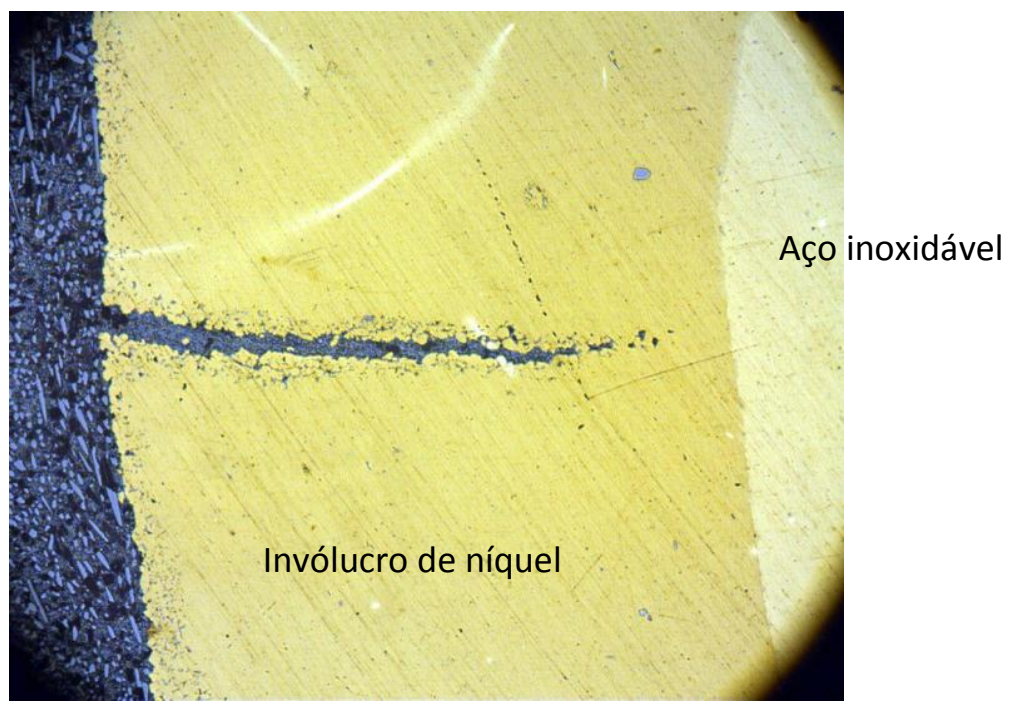

Figura 59. Micrografia óptica mostrando trinca na porção sinterizada do compactado com origem na superfície.

A Fig. 60, obtida em microscopia eletrônica de varredura, mostra interfaces do sinterizado de níquel com cobre e o núcleo em aço AISI 304, confirmando que o compactado em geral é bem denso não havendo descontinuidades na interface níquel aço inoxidável. 


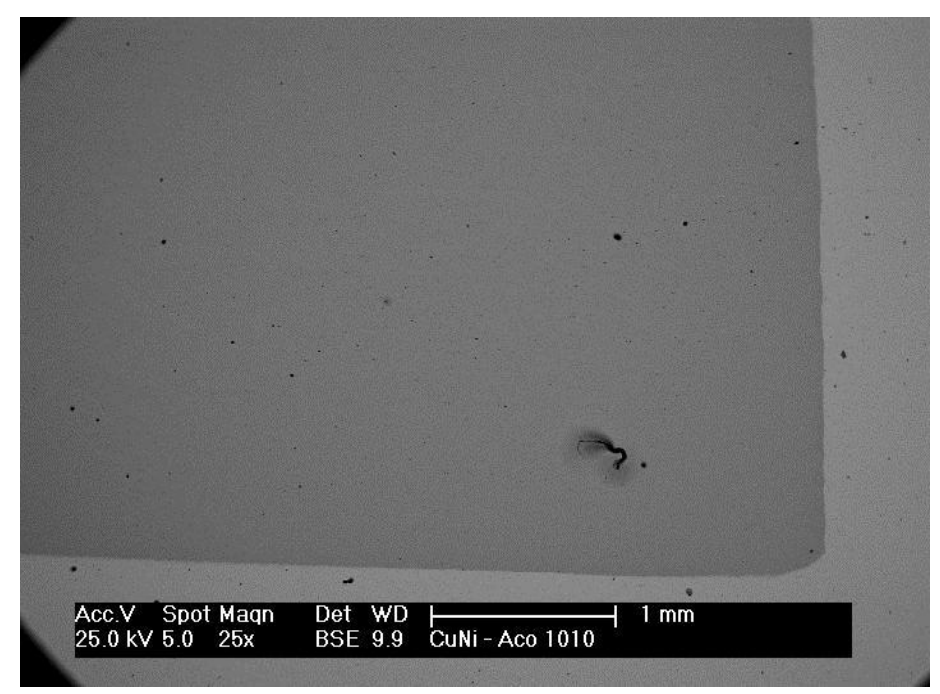

Figura 60. Micrografia eletrônica de varredura de um corte do compactado de níquel com o núcleo em aço AISI 304.

Outra amostra foi preparada, mas sem o núcleo em aço AISI 304 e sinterizada nas mesmas condições da peça anterior. Neste caso, após a sinterização a peça apresentou um bom aspecto visual quando analisada em microscópio óptico. Poros pequenos e bem arredondados foram observados. Para avaliação da estrutura interna dos compactados, os mesmos foram cortados ao meio e embutidos com resina a frio. As amostras foram preparadas metalograficamente e analisadas por microscopia eletrônica de varredura, vide Fig. 61.

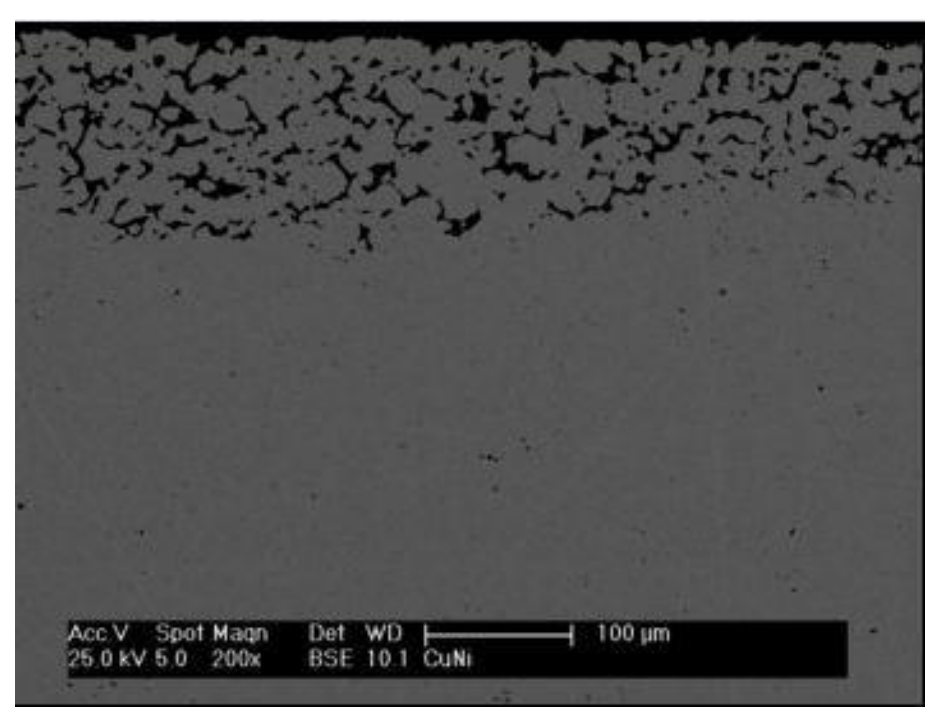

Figura 61. Micrografia eletrônica de varredura com elétrons retro-espalhados de um corte do compactado sinterizado de níquel com infiltração de cobre. Foi observado que a borda ficou porosa. 


\section{CONCLUSÃO}

Como considerações principais cabe-se destacar.

- Os resultados obtidos com a sinterização envolvendo o pó de níquel, apontam para a viabilidade de se obter um invólucro para alvos de urânio a partir desse material.

- Verificou-se que utilizando pressão de compactação de $195 \mathrm{MPa}$, temperatura de sinterização $600{ }^{\circ} \mathrm{C}$, em atmosfera de proteção com cavacos de titânio, não foi suficiente para eliminar porosidade interconectada.

- Diferentes pressões de compactação promoveram uma maior densidade relativa do compactado, sendo que a pressão de compactação de $800 \mathrm{MPa}$ apresentou um valor de densidade relativa acima de $85 \%$ da densidade teórica.

- Mantendo-se o patamar de $600{ }^{\circ} \mathrm{C}$ por um período de $4 \mathrm{~h}+8 \mathrm{~h}$, não foi observado sinais de mudanças significativas na densificação das amostras compactadas, independentemente da pressão de compactação aplicada.

- Quanto à sinterização em atmosfera controlada de argônio, hidrogênio e alto vácuo, observou-se que houve sinterização no centro do compactado sendo que as bordas ficaram muito porosas.

- Os resultados preliminares indicam que a prensagem a $195 \mathrm{MPa}$ e sinterização a $600{ }^{\circ} \mathrm{C}$ por $24 \mathrm{~h}$ em atmosfera de hidrogênio implicam na melhor densificação do compactado, obtendo $78 \%$ de densidade relativa, entretanto não foi suficiente para evitar poros interconectados.

- O uso da prensagem isostática mostrou-se promissora para a montagem de um compactado com núcleo, embora não se tenha evidência do motivo das porosidades encontradas nas bordas.

- A sinterização por dois corpos (níquel com cobre) apresenta-se como uma técnica promissora para o uso como invólucro para núcleos, em termos de integridade estrutural e selamento devido a ausência de porosidade interconectada. 


\section{SUGESTÃO DE TRABALHO FUTURO}

Recobrir o compactado de níquel com uma camada de níquel eletrodepositado de forma a selar toda a superfície externa. Avaliar a espessura e homogeneidade desta camada de cobertura utilizando técnicas eletroquímicas por EIE (impedância eletroquímica). Do ponto de vista microestrutural, fazer uma caracterização por análise por difração de raios $X$ e microscopia óptica $e$ eletrônica de varredura das fases presentes no invólucro de níquel e cobre. Avaliar a resistência da camada em solução ácida $(\mathrm{pH}=5)$ com relação ao tempo. Utilizar ensaios de dureza e mecânicos para avaliar a fragilidade da estrutura. Avaliar a resistência e condição do compactado nas temperaturas de irradiação. 


\section{REFERÊNCIAS}

ABRAMS, L.; MAYNARD R.; FAVORITE, C. Correction for compressibility in mercury intrusion measurements. The Micro Report 7, 1996.

ALLEN, T. Particle Size Measurement; Chapman and Hall; 4th Ed.; p 456, London, 1990.

ALLEN, T. Particle Size Measurement. Surface Area and Pore Size Determination. V. 2, Springer, 1997.

ALMEIDA, A. W. Ligas: Diagrama de Fases. Disponível em: $<$ http://www.eletrica.ufpr.br/piazza/materiais/AdrianoAlmeida.pdf>. Acessado em 24/02/2009.

ANDRADE, M. L. A.; CUNHA, L. D.; GANDRA, G. T.; RIBEIRO, C. C. "Níquel Novos parâmetros de desenvolvimento. "Gerencia Setorial de Mineração e Metalurgia. Banco Nacional de desenvolvimento. Disponível: http://www.bndes.gov.br, 2000. Acessado em 02/03/2014.

ARAÚJO, E. B. A utilização do elemento Tecnécio-99m no diagnóstico de patologias e disfunções dos seres vivos. Redes, v. 2, n. 131, 2014.

ASM Specialty Handbook: Nickel, Cobalt, and their Alloys. ASM International Materials Park, Ohio, 2000.

BANERJEE, S.; PILLAI, M. R. A.; RAMAMOORTHY, N. Evaluation of Tc-99m in diagnostic radiopharmaceuticals. Seminars in Nuclear Medicine, v. 31, n. 4, p. 260-277, 2001.

BORGES, W. A.; Estudos de simulação computacional do processo de redução de UF4 a Urânio Metálico. Dissertação de Mestrado, Universidade de São Paulo, 2011.

BOYD, R. E. Technetium-99m Generators - The available options. The International Journal of Applied Radiation and Isotopes, v. 33, p. 801-809, 1982.

CHAKRABARTI, D. J.; PETERSON D. E. Ni - U (Nickel - uranium). In: MASSALSKI, T. B. (ed.) Binary Alloy Phase Diagrams, ASM International, Materials Park, Ohio, 2nd Ed., v. 1, p. 369-371, 1990.

CHIAVERINI, V. Metalurgia do pó. Associação Brasileira de Metalurgia e Materiais, 2001. 
COLS, H.; CRISTINI, P. R.; MARQUES, R. O. Preliminary investigations on the use of uranium silicide targets for fission ${ }^{99}$ Mo production. In: RERTR-1994 International Meeting on Reduced Enrichment for Research and Test Reactors, Williamsburg, Virginia, Argonne National Laboratory Report, ANL/RERTR/Tm, 20 September, p. 18-23, 1994.

CRISTINI, P. R., COLS, H. J., BAVARO, R., BRONCA, M., CENTURIÓN, R., CESTAU, D. Production of molybdenum-99 from low enriched uranium targets. In: Proceedings of the $\mathbf{2 0 0 2}$ International Meeting on Reduced Enrichment for Research and Test Reactors, San Carlos de Bariloche, Argentina, November 2002.

DEYOUNG, J. H.; SUTPHIN, D. M.; WERNER, A. B. T.; FOOSE, M. P. International strategic minerals inventory summary report - nickel. US Geol. Surv. Circ., 930-D, 1985.

EMSLEY, J. Nature's Building Blocks: an AZ Guide to the Elements. Oxford University Press, 2011.

EVANS, J. V.; MOORE, P. W.; SHYING, M. E.; SODEAU, J. M. Zirconium molybdate gel as a generator for technetium-99m - I. The concept and its evaluation. Intern. J. of Radiation App. and Instr. Part A. Applied Radiation and Isotopes, v. 38, n. 1, p. 19-23, 1987.

FABRO, J.; RESTELLI, M.; PODESTÁ, D.; ROSSI, G.; BOERO, N. Development of LEU Targets for Mo-99 Production. Potential Mo-99 Producers Workshop, May 17-19, Buenos Aires, Argentina, 2005.

FERREIRA, F. C.; CARDOSO, L. X.; COSTA, M. J. C.; CUNHA, C. J.; SOUZA, D. N. Avaliação de ${ }^{99}$ Mo em amostra de $99 \mathrm{mT}$ c em clínicas de medicina nuclear no Sergipe. Scientia Plena, v. 4, n. 11, 2008.

FERRETO, H. F. R., Nova metodologia para o estudo da recuperação do urânio nas escorias provenientes da produção do urânio metálico, Dissertação de Mestrado IPEN/USP - São Paulo, 1999.

GERMAN, R. M. Powder Metallurgy of Iron and Steel, New York, N.Y. : John Wiley \& Sons Inc, 1st Ed. 1998.

GERMAN, R. M. Powder Metallurgy Science. Princeton, NJ, Metal Powder Industries Federation, p. 113-114, 1984.

GOETZEL, C. G. Cermets. In: KLAR, E. (Coord.). Metals handbook: Powder Metallurgy, 9. Ed. Ohio, American Society for Metals, v. 7, p. 798-815, 1984.

GOLDMAN, I. N.; RAMAMOORTHY, N. and ADELFANG, P. Progress and status of the IAEA coordinated research project: production of Mo-99 using LEU fission or neutronic activation. RERTR 2007 - International Meeting on Reduced Enrichment for Research and Test Reactors, September 23-27, Prague, Czech Republic, 2007.

GREETHAM, G. Development and performance of infiltrated and non-infiltrated valve seat insert materials and their performance. Powder Metallurgy, v. 33, n. 3, p. 112-124, 1990.

HANDBOOK. Höganäs Handbook for Sintered Components - Material and Powder Properties. v. 1, 1997. 
HENRY, H. H. Handbook of Powder Metallurgy. Chemical Publisher Co. Inc, New York, 1973.

HIRSCHHORN, J. S. Introduction to Powder Metallurgy. Princeton, NJ. American Powder Metallurgy Institute, 1969.

HOFMAN, G. L.; WIENCEK, T. C.; WOOD, E. L.; SNELGROVE, J. L.; SURIPTO, A.; NASUTION, H.; LUFTI-AMIN, D.; GOGO, A. Irradiation tests of 99Mo isotope production employing uranium metal foils. 19th International Meeting on Reduced Enrichment for Research and Test Reactors. p. 1-14, 1996.

IACOCCA, R. G.; GERMAN, R. M. A Comparison of powder particle size measuring instruments. Intern. J. of Powder Metallurgy, v. 33, n. 8, p.35-48, 1997.

IASI, M. M. Comunicação pessoal. www.combustol.com.br / www.metalpo.com.br. Agosto 2014.

IMPE, J. V. Uranium and fabrication. Chem. Eng. Progress Symposium. 1954.

INTERNATIONAL ATOMIC ENERGY AGENCY. Production and Supply of Molybdenum-99. NTR 2010 Supplement. 54 ${ }^{\text {th }}$ General Conference, IAEA, Vienna, 2010.

JESUS FILHO, E. S., Processamento, Usinagem e Desgaste de Ligas Sinterizadas para Aplicações Automotivas. Tese Doutorado IPEN/USP - São Paulo, 2006.

JONES, R. T. AEC-2 Experiments in Support of ${ }^{99}$ Mo Production in NRU. Atomic Energy of Canada, Ltd, 1982.

KATZ, J. J.; GLENN T. S. The Chemistry of the Actinide Elements. London: Methuen \& Co. Ltd, 1957.

KLAR, E.; JAMES W. F. Gas and Water Atomization. ASM Handbook, ASM International, USA, p. 25-39, 1984.

LACHANCE, G. R. O.; CLAISSE, F. Quantitative X-ray Fluorescence Analysis. Theory and Application. New York, John Wiley \& Sons, 1995.

LAMARSH, J. R. Introduction to Nuclear Reactor Theory. Addison, 1972.

LEDERER, C. M.; SHIRLEY, V. S. (Ed.) Table of Isotopes. John Wiley and Sons, Inc., 7th ed. New York, 1978.

LENEL, F.V. Mechanical Fundamentals of consolidation, Metal Handbook $9^{\text {th }}$ Ed., Powder Metallurgy, American Society for Metals, v. 7, p. 298-307, 1984.

LIMA, R. M. de; Relatório MU-No 03/92, CNEN-SP-IPEN, Relatório interno do Projeto Urânio Metálico, IPEN, 1992.

LIMA, R. M. de; Relatório MU-N 04/92, CNEN-SP IPEN. Relatório interno do Projeto Urânio Metálico, IPEN, 1992.

LOBERTO A. Efeitos da adição de boro e da atmosfera de sinterização na densificação e nas propriedades mecânicas da liga Fe-0,3\%C produzida por metalurgia do pó. Dissertação de Mestrado - Universidade Federal - ABC - São Paulo, 2012. 
MARCONDES, F. C. A História do Metal Duro. Consultoria de Projetos e Artes, 1990.

MATOS, E. C.; RUBINI, L. A. Reservas Brasileiras de Urânio e sua

Capacidade de Atendimento à Demanda Interna. Indústrias Nucleares do Brasil S.A. - INB, 1999.

METALLUM EVENTOS TÉCNICOS “A Metalurgia do Pó: Alternativa Econômica com Menor Impacto Ambiental”, 1ª ed., p. 106, 2009.

MOON, J. R. Sintering of Metal Powders. Powder Metall. Inter., v. 3, p. 147-152, 1979.

NATIONAL RESEARCH COUNCIL (NRC). Medical Isotope Production without Highly Enriched Uranium. Washington, DC: The National Academic Press. 2009.

NIETO, R. C. Estudos do Efeito da Irradiação em um Reator Nuclear, de Alvos Contendo Mo Utilizados para o Preparo do Gel de ${ }^{99} \mathrm{Mo}$, Material Constituinte dos Geradores de ${ }^{99} \mathrm{Mo}-{ }^{-9 \mathrm{~m}} \mathrm{Tc}$. Dissertação de Mestrado, Universidade de São Paulo, 2004.

NISHIYAMA, P. J. B. O. Análises Neutrônica e Termo-Hidráulica de um Dispositivo para Irradiação de Alvos Tipo LEU de UAlx-Al para Produção de ${ }^{99}$ Mo no Reator IEA-R1. Dissertação, IPEN / USP São Paulo, 2012.

OLIVEIRA, M. M.; BOLTON, J. D. High-speed steels: increasing wear resistance by adding ceramic particles. J. Materials Proces. Tech., v. 92, p. 15-20, 1999.

ROUQUEROL, J.; AVNIR, D.; FAIRBRIDGE, C. W.; EVERETT, D. H.; HAYNES, J. M.; PERNICONE, N.; RAMSAY, J. D. F.; SING, K. S. W.; UNGER, K. K. Recommendations for the characterization of porous solids (Technical Report). Pure and Applied Chemistry, v. 66, n. 8, p. 1739-1758, 1994.

SALIBA-SILVA, A. M., GARCIA, R. H. L., MARTINS, I. C., CARVALHO, E. F. U. D.; DURAZZO, M. Uranium briquettes for irradiation targets. International Nuclear Atlantic Conference - (INAC), 2011.

SAMEH, A. A.; ACHE, H. J. Production Techniques of Fission ${ }^{99} \mathrm{Mo}$. In: Proceedings of a Technical Committee Meeting Organized by The International Atomic Energy Agency. IAEA-TECDOC-515, p. 47,1989.

SCHRADER, R.; KLEIN, J.; MEDEL, J.; MARÍN, J.; LISBOA, J.; BRISTEIN, L.; AHUMADA, L.; CHANDÍA, M.; BECERRA, R.; ERRAZU, X.; ALBORNOZ, C.; SYLVESTER, G.; JIMÉNEZ, J. C. Status of the Chilean implementation of the modified cintichen process for fission ${ }^{99}$ Mo production using LEU In: RERTR 2008 - International Meeting on Reduced Enrichment for Research and Test Reactors. Washington D.C., USA, October 5-9, 2008.

SCHRADER, R.; KLEIN, J.; MEDEL, J.; MARÍN, J.; SALAZAR, N.; BARRERA, M.; ALBORNOZ, C.; CHANDÍA, M.; ERRAZU, X.; BECERRA, R.; SYLVESTER, G.; JIMÉNEZ, J. C.; VARGAS, E. Progress in Chile in the development of the fission ${ }^{99}$ Mo production using modified CINTICHEN. In: RERTR 2007 - International Meeting on Reduced Enrichment for Research and Test Reactors. September 23-27, Prague, Czech Republic, 2007. 
Edgard Blücher, São Paulo, 1987.

SHEA, W. R., ed. Otto Hahn and the Rise of Nuclear Physics. V. 22. Springer, 1983.

SILVA, A. G. P.; ALVES Jr., C. A. A sinterização rápida: sua aplicação, análise e relação com as técnicas inovadoras de sinterização. Cerâmica, v. 44, n. 290, p.225-232, 1998.

SMITH, L. N.; MIDHA, P. S.; GRAHAM, A. D. Simulation of metal powder compaction, for the development of a knowledge based powder metallurgy process advisor. J. Materials Processing Tech., v. 79, n. 1, p. 94-100, 1998.

TAKAHASHI, S. Y., Estudo comparativo da relação custo benefício dos métodos de produção de ${ }^{99} \mathrm{Mo}$ : fissão de ${ }^{235} \mathrm{U}$ e reação de captura neutrônica no ${ }^{98}$ Mo, Dissertação IPEN/USP - São Paulo, 2004.

THÜMMLER, F.; OBERACKER, R. An Introduction to Powder Metallurgy, The University Press, Cambridge, 1993.

THÜMMLER, F.; THOMNA, W. The Sintering Process. Metallurgical Reviews, 12.1, 69-108, 1967.

VANDEGRIFT, G. F. Facts and Myths Concerning ${ }^{99}$ Mo Production with HEU and LEU Targets. In: RERTR 2005 - International Meeting on Reduced Enrichment for Research and Test Reactors, November 6-10. Boston, USA, 2005.

VANDEGRIFT, G. F.; BAKEL, A. J. and THOMAS, J.W. Overview of 2007 ANL Progress for conversion of HEU-based Mo-99 Production as part of the U.S.

Global Threat Reduction-Conversion Program. In: RERTR 2007 - International Meeting on Reduced Enrichment for Research and Test Reactors, September 23-27. Prague, Czech Republic, 2007.

WEBB, P. A.; CLYDE, O.; Analytical Methods in Fine Particle Technology; Micromeritics Instrument Corp, 1997.

ZAPATA, C. W. Ciclo de palestras sobre metalurgia do pó. FEJ/ UDESC. Joinville, dez. 1987. 